COVER PHOTOGRAPHS

\begin{tabular}{|c|c|c|c|c|}
\hline 1 & 2 & 3 & 4 & 1. Asbestos ore \\
\hline 1 & & 3 & 4 & 2. Lead ore, Balmat mine, N. Y. \\
\hline \multirow[t]{2}{*}{5} & & 6 & & 3. Chromite, chromium ore, Washington \\
\hline & 7 & & 8 & 5. Banded iron-formation, Palmer, \\
\hline 9 & & 10 & & $\begin{array}{l}\text { Mich. } \\
\text { 6. Ribbon asbestos ore, Quebec, Canada }\end{array}$ \\
\hline 11 & 12 & 13 & 14 & $\begin{array}{l}\text { 7. Manganese ore, banded } \\
\text { rhodochrosite }\end{array}$ \\
\hline
\end{tabular}

8. Aluminum ore, bauxite, Georgia 9. Native copper ore, Keweenawan Peninsula, Mich.

10. Porphyry molybdenum ore, Colorado

11. Zinc ore, Edwards, N.Y.

12. Manganese nodules, ocean floor

13. Botryoidal fluorite ore.

Poncha Springs, Colo.

14. Tungsten ore, North Carolina 


\section{Alkalic Rocks and Resources of Thorium and Associated Elements in the Powderhorn District, Gunnison County, Colorado}

By JERRY C. OLSON and DAVID C. HEDLUND

GEOLOGY AND MINERAL RESOURCES OF THORIUM IN THE UNITED STATES

GEOLOGICAL SUR VEY PROFESSIONAL PAPER 1049-C

An evaluation of thorium resources, their distribution, and

geologic relationships 


\section{UNITED STATES DEPARTMENT OF THE INTERIOR}

JAMES G. WATT, Secretary

GEOLOGICAL SURVEY

Doyle G. Frederick, Acting Director

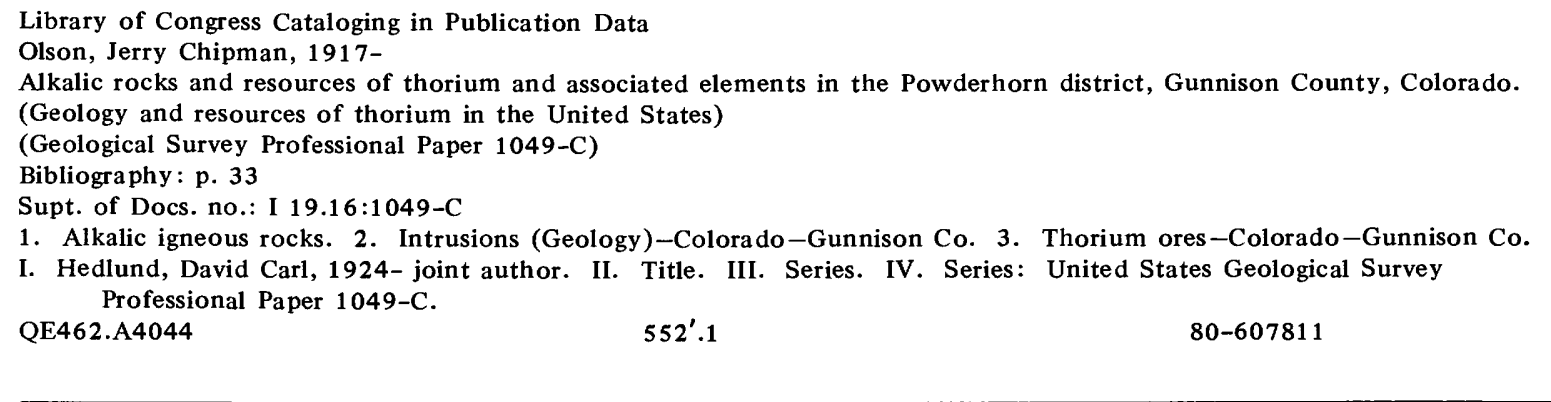

For sale by the Superintendent of Documents, U.S. Government Printing Office Washington, D.C. 20402 


\section{CONTENTS}

Introduction

General geology

Purpose and scope of report

Fieldwork and acknowledgments

Precambrian rocks

Volcanogenic mineral deposits

Syenites and related rocks

Upper Proterozoic or lower Paleozoic igneous rocks

Alkalic rock complex of Iron Hill

Fenite

Pyroxenite

Magnetite-ilmenite-perovskite rock

Uncompahgrite -

Ijolite

Nepheline syenite

Carbonatite of Iron Hill

\begin{tabular}{r|r} 
Page & \\
1 & Carbonatite dikes - \\
2 & Igneous rocks and veins outside the complex of Iron Hill - \\
2 & Trachyte porphyry dikes \\
2 & Fine-grained granite \\
3 & Thorite veins \\
3 & Diabase and gabbro dikes \\
3 & Faults \\
3 & Resources of thorium and associated elements \\
4 & Thorium - \\
5 & Associated elements \\
6 & Niobium - \\
8 & Titanium \\
13 & Iron - \\
14 & Vanadium \\
14 & Rare-earth elements \\
15 & Uranium \\
\hline 16 & References -
\end{tabular}

Page

19

20

20

21

22

24

\section{ILLUSTRATIONS}

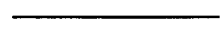
(n) 
FIGURE 24. Graph showing relation of total cerium-group rare-earth metals to $\mathrm{ThO}_{2}$ content in 59 samples of thorium deposits

\section{TABLES}

TABLE 1. Chemical analyses of Powderhorn Granite and fenite

2. Semiquantitative spectrographic analyses of melanite, diopside, perovskite, and magnetite from pyroxenite, complex of Iron Hill

3. Semiquantitative spectrographic, X-ray fluorescent, fluorometric, and radiochemical analyses of pyrochlore and apatite from carbonatite, Iron Hill

4. $\mathrm{ThO}_{2}$ resources

5. Indicated and inferred reserves of $\mathrm{ThO}_{2}$ in veins of more than $500 \mathrm{ppm} \mathrm{ThO}_{2}$ average grade

6. $\mathrm{ThO}_{2}$ content of magnetite-ilmenite-perovskite rock, complex of Iron Hill

7. $\mathrm{ThO}_{2} / \mathrm{Nb}_{2} \mathrm{O}_{5}$ ratios in veins in the Powderhorn district

8. Ratio of cerium-group rare-earth oxides to $\mathrm{ThO}_{2}$ to yttrium-group rare-earth oxides in various thorium deposits 


\title{
ALKALIC ROCKS AND RESOURCES OF THORIUM AND ASSOCIATED ELEMENTS IN THE POWDERHORN DISTRICT, GUNNISON COUNTY, COLORADO
}

\author{
By JERRY C. Olson and DAVID C. Hedlund
}

\section{ABSTRACT}

Alkalic igneous rocks and related concentrations of thorium, niobium, rareearth elements, titanium, and other elements have long been known in the Powderhorn mining district and have been explored intermittently for several decades. The deposits formed chiefly about 570 m.y. (million years) ago in latest Precambrian or Early Canibrian time. They were emplaced in lower Proterozoic (Proterozoic X) metasedimentary, metavolcanic, and plutonic rocks.

The complex of alkalic rocks of Iron Hill occupies $31 \mathbf{~ k m}^{2}$ (square kilometers) and is composed of pyroxenite, uncompahgrite, ijolite, nepheline syenite, and carbonatite, in order of generally decreasing age. Fenite occurs in a zone, in places more than $0.6 \mathrm{~km}$ (kilometer) wide, around a large part of the margin of the complex and adjacent to alkalic dikes intruding Precanıbrian host rock. The alkalic rocks have a radioactivity, chiefly due to thorium, greater than that of the surrounding Powderhorn Granite (Proterozoic X) and metaniorphic rocks. The pyroxenite, uncompahgrite, ijolite, and nepheline syenite, which form more than $\mathbf{8 0}$ percent of the complex, have fairly uniform radioactivity. Radioactivity in the carbonatite stock, carbonatite dikes, and the carbonatite-pyroxenite mixed rock zone, however, generally exceeds that in the other rocks of the complex.

The thorium concentrations in the Powderhorn district occur in six types of deposits: thorite veins, a large massive carbonatite body, carbonatite dikes, trachyte dikes, magnetite-ilmeniteperovskite dikes or segregations, and disseminations in small, anomalously radioactive plutons chiefly of granite or quartz syenite that are older than rocks of the alkalic complex.

The highest grade thorium concentrations in the district are in veins that commonly occur in steeply dipping, crosscutting shear or breccia zones in the Precambrian rocks. They range in thickness from a centimeter or less to $5 \mathrm{~m}$ (meters) and are as much as $1 \mathrm{~km}$ long. The thorite veins are composed chiefly of potassic feldspar, white to smoky quartz, calcite, barite, goethite, and hematite, and also contain thorite, jasper, magnetite, pyrite, galena, chalcopyrite, sphalerite, synchysite, apatite, fluorite, biotite, sodic amphibole, rutile, monazite, bastnaesite, and vanadinite. The $\mathrm{ThO}_{2}$ content of the thorite veins ranges from less than 0.01 percent to as much as 4.9 percent in high-grade samples. The $\mathrm{ThO}_{2}$ content is generally less than 1 percent, however, and is only 0.05 to 0.1 percent in many of the veins examined in the district.

Samples of the dolomitic carbonatite of Iron Hill mostly range from 3 to $145 \mathrm{ppm}$ (parts per million) thorium. Thirty samples of the carbonatite dikes, the most radioactive rocks within the complex of Iron Hill, contain about 30 to $3,200 \mathrm{ppm}$ thorium and a trace to about 1.5 percent rare-earth oxides.

The magnetite-ilmenite-perovskite rocks have a radioactivity of 2 to 12 times the background of Precanibrian granite that is attributable chiefly to thorium substitution for calcium in the perovskite. In two analyses the perovskite contains 0.12 and 0.15 percent $\mathrm{ThO}_{2}$.

Trachyte dikes as much as $\mathbf{2 5} \mathrm{m}$ thick cut the Precanibrian rocks; their radioactivity is generally about two to four times the background of typical Precamırian granite, is locally higher, but is low relative to other types of thorium concentrations. A finegrained granite that is anomalously radioactive occurs in thick, dikelike plutons as much as $1.2 \mathrm{~km}$ wide, or more. The thorium content varies widely within the granite bodies. Eight sanıles of the granite contain 32 to $281 \mathrm{ppm}$ thorium (averaging $115 \mathrm{ppm}$ ).

The economic potential of thorium in the Powderhorn district is related in part to other elements such as niobium, titanium, iron, and rare earths. The proportions of niobium and rare earths to thorium vary in different parts of the district. Within the carbonatite body of Iron $\mathrm{Hill}$, the $\mathrm{Nb}_{2} \mathrm{O}_{5}$ content greatly exceeds $\mathrm{ThO}_{2}$, but the $\mathrm{ThO}_{2}-\mathrm{Nb}_{2} \mathrm{O}_{5}$ ratio increases markedly northwestward to as high as 10.7 in vein deposits near the northwest end of the district.

The ratio of cerium-group rare-earth oxides to $\mathrm{ThO}_{2}$ to yttriumgroup rare-earth oxides in the district is roughly 3.6 to 1 to 0.5 , but this ratio varies considerably in different parts of the district. For example, the proportion of the cerium group is greatest in and near the complex of Iron Hill, and is least in an area of thorite veins about $6 \mathrm{~km}$ to the north. The proportion of the yttrium group in these two areas varies approximately inversely to that of the cerium group.

Thorium deposits shown on the geologic quadrangle maps of the Powderhorn district number at least 261. Most are small or low in grade, hence only a minority contribute significantly to total resources. Indicated and inferred reserves of $\mathrm{ThO}_{2}$ total about 10,000 short tons in rock greater than 0.1 percent $\mathrm{ThO}_{2}$ in grade. This estimated tonnage is in 15 deposits including 13 veins and two carbonatite dikes. Larger amounts of thorium are present in lower grade materials. Additional quantities are probably present in deposits as yet undiscovered, which could add significantly to the total resources. 


\section{INTRODUCTION}

The Powderhorn district is a $650 \mathrm{~km}^{2}$ area in Gunnison County, Colo., that has long been known for its occurrences of alkalic igneous rocks and related concentrations of thorium, niobium, rare-earth elements, titanium, and other metals. This mapping and geologic study of the district was undertaken primarily to learn more about the geologic occurrence and origin of the mineral deposits listed above and to evaluate their economic potential and resources.

Mining activity in the district began in 1872 and has continued intermittently to the present. The early mining was chiefly for gold, silver, copper, lead, zinc, and arsenic from veins and volcanogenic massive sulfide deposits. In more recent years mining and prospecting has been aimed toward thorium, rareearth elements, niobium, and titanium as well. Various attempts have been made to mine and process vermiculite, particularly about $1935-45$, by the Black Mica Mining Co., Allied Minerals Co., and the Alexite Co.

Thorium veins were discovered in the Powderhorn district in 1949, and about 250 veins were prospected for thorium during 1949-56. In order to assess niobium resources, the pyrochlore-bearing carbonatite and related rocks of the complex of Iron Hill were drilled and an adit was driven by the DuPont Co. in 1957-58. Titaniferous iron ores in the complex have been prospected at various times since their discovery in the 1880's. The Humphreys Gold Corp. explored the titanium deposits by digging test pits in the early fifties, and in 1957 the complex was investigated by the U.S. Bureau of Mines by drilling and surface sampling. In the mid-1970's the titanium deposits were being explored by Buttes Gas and Oil Co.

\section{GENERAL GEOLOGY}

The area is underlain largely by metasedimentary and metavolcanic rocks intruded by Precambrian granitic and other igneous rocks. In late Precambrian or Cambrian time, about 570 m.y. ago, the Precambrian rocks were intruded by alkalic igneous rocks of Iron Hill and by slightly younger tholeiitic diabase dikes (Olson and others, 1977). Mesozoic sedimentary rocks and Tertiary volcanic rocks originally covered much of the area and now remain as scattered mesas and ridges where they cover the older rocks.

The geology of the complex of Iron Hill has been described by Larsen (1942), Temple and Grogan (1965), Rose and Shannon (1960), and Nash (1972). The thorium deposits in the Powderhorn district have been described by Burbank and Pierson (1953), Hedlund and
Olson (1961), and by Olson and Wallace (1956), who included a detailed map and description of one of the largest thorium deposits, the Little Johnnie vein. The thorium content of the Iron Hill carbonatite stock has been studied by Armbrustmacher (1980). The geology of the district and location of thorium deposits are shown on geologic quadrangle maps by Hedlund and Olson $(1973,1975)$, Olson and Hedlund (1973), and Olson (1974).

\section{PURPOSE AND SCOPE OF REPORT}

This report focuses primarily on the distribution of thorium and associated elements in various rock types, the evaluation of resources of thorium in different areas and types of deposits, and the relation of the mineral deposits to geologic history and structural features. We have tried to avoid excessive duplication of data already published in the extensive literature on the district, listed in references at the end of the report. Accordingly, the reader is referred to these reports for additional information on rock descriptions, mineralogy, geologic maps, analyses of rocks and minerals, descriptions of selected deposits, and other geologic features not specifically treated herein.

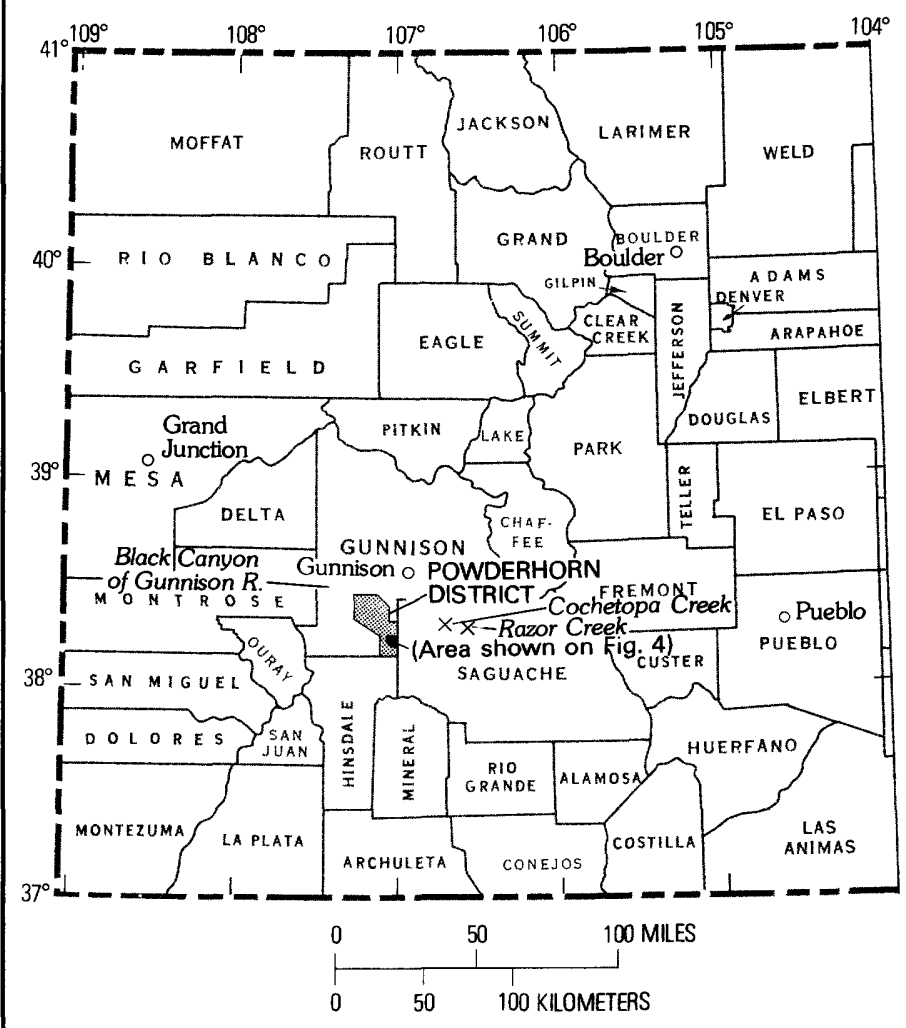

FIGURE 1.-Index map of Colorado showing location of Powderhorn district, Gunnison County. 


\section{FIELDWORK AND ACKNOWLEDGMENTS}

This report is based chiefly on the geologic mapping of the Powderhorn, Rudolph Hill, Gateview, Carpenter Ridge, and Big Mesa $7 \frac{1}{2}$ minute quadrangles by J. C. Olson and D. C. Hedlund during 1956-63. During the mapping, 261 thorium deposits and numerous other mines and prospects were examined briefly with a scintillation counter, and some resources were estimated. In 1976 and 1977, Olson reexamined 67 of the deposits with the aid of a portable four-channel gamma-ray spectrometer and collected additional samples. These 101 samples were analyzed in the laboratory by C. M. Bunker and C. A. Bush by gammaray spectrometry to provide an approximate calibration of thorium content and the field readings.

Laboratory work has included petrographic study of many thin sections, chemical and spectrographic analyses of rock samples, and mineralogical studies. The analytical work is summarized briefly in this report, but the 178 analyses of rock and thorium vein samples are available in Hedlund and Olson (1980).

Mineral exploration companies and prospectors in the district gave friendly cooperation during the work. R. M. Grogan and A. K. Temple of the DuPont Co. provided information on drilling and access to drill-core samples. S. S. Shannon of the U.S. Bureau of Mines made available thin sections and drill-core data from various parts of the pyroxenite of the complex of Iron Hill. T. J. Armbrustmacher provided radiometric and mineralogic information on the carbonatite body. M. H. Staatz identified minerals in 23 samples of thorium veins. I. $K$. Brownfield made heavy-liquid separations and X-ray diffractograms of mineral concentrates from some of the thorium-bearing rocks and veins.

The estimation of costs to produce thorium from various types of deposits used a method of cost analysis designed by Lemons and Coppa (1979).

\section{PRECAMBRIAN ROCKS}

The oldest rocks in the Powderhorn district are metasedimentary and metavolcanic rocks that were deposited to great thickness largely in a trough beneath the sea. These rocks were metamorphosed, mostly to amphibolite facies, about 1.7 billion years ago, probably shortly after their deposition. This regional metamorphism has not been dated in the Powderhorn area but is probably part of the widespread metamorphism known in many places in Colorado to be of about this age. The grade of metamorphism increases generally northwestward in the district to as high as the sillimanite subfacies. Migmatite and small dikes and lenses of pegmatite were formed locally in the northwestern part of the district. The metamorphic rocks throughout the district were intruded by plutons of granitic to quartz dioritic composition and by small, more mafic intrusive bodies. None of the concentrations of thorium and related minor elements appear to be related in origin to this older, 1.7-1.8 billion-year chapter of Precambrian history.

\section{VOLCANOGENIC MINERAL DEPOSITS}

Massive sulfide deposits and veins containing gold, silver, copper, lead, zinc, and locally telluride minerals occur in the metavolcanic rocks of the Dubois Greenstone of Proterozoic $\mathrm{X}$ age in an east to northeasttrending zone termed the Gunnison gold belt. These volcanogenic copper- and gold-bearing deposits differ markedly from the quartz-orthoclase-carbonate-baritethorite veins. The Gunnison gold belt deposits, which show no anomalous radioactivity, commonly strike northeast to east, generally parallel with the overall trend of the metavolcanic and metasedimentary formations, whereas the thorite veins are in younger fractures that cut discordantly across the country rocks. In the volcanogenic deposits pyrite is the principal sulfide, with local concentrations of chalcopyrite, arsenopyrite, sphalerite, galena, or native gold. The quartz of these veins differs from that of the thorite veins, being generally finer grained and chloritic. Spatial relations to the sequence of metavolcanic rocks indicate that the massive sulfide deposits of the Gunnison gold belt were formed at least 1,700 m.y. ago at about the time the enclosing volcanic and sedimentary rocks were deposited. The gold-bearing quartz-chlorite veins were formed slightly later, as they are discordant to their host rocks, but are also Precambrian in age.

\section{SYENITES AND RELATED ROCKS}

The older Precambrian rocks were intruded by small plutons of leucosyenite and melasyenite about 1,400 m.y. ago (Olson and others, 1977). About 20 of these small stocks or plugs, the largest about 0.6 by $1.3 \mathrm{~km}$, and numerous smaller dikes, occur in the district. They are mostly in the north half of the Gateview and Powderhorn quadrangles and the southeastern part of the Carpenter Ridge quadrangle (Hedlund and Olson, 1973). The individual plutons are generally composite, consisting of several textural and compositional varieties of leucosyenite and melasyenite. Typical augite syenite, shown in figure 2 , contains augite and 


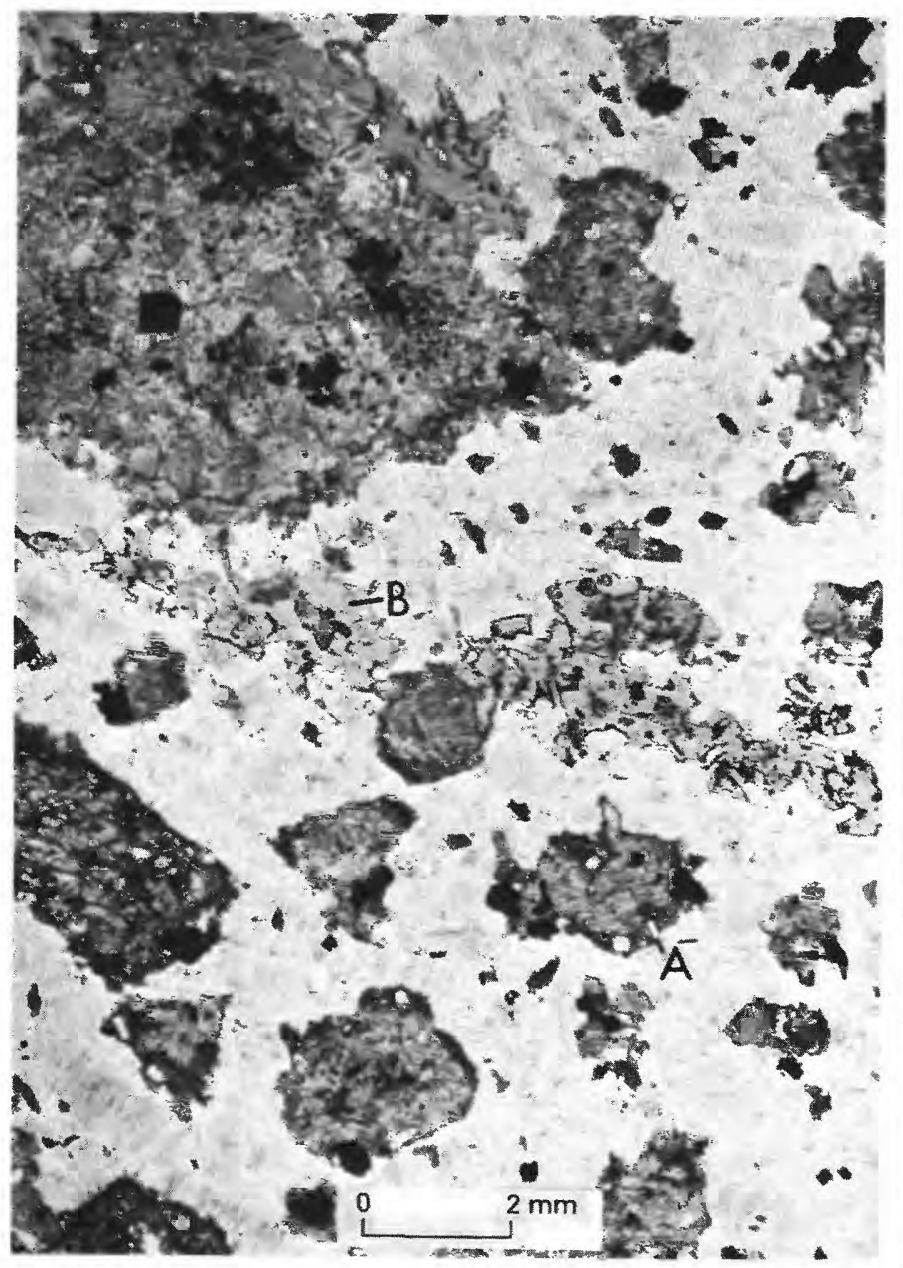

Figure 2.-Augite syenite from intrusive body near Spencer, Powderhorn quadrangle. Augite (A) and biotite (B) phenocrysts are set in a fine-grained groundmass consisting chiefly of microcline laths.

biotite phenocrysts in a fine-grained groundmass consisting chiefly of microcline laths. The biotite phenocrysts are highly poikilitic and locally segmented. The augite phenocrysts show various stages of alteration to uralitic hornblende, chlorite, ferric oxides, and biotite. About 65 chemical, spectrographic, and modal analyses have been given by Hedlund and Olson (1980).

The 1,400-m.y.-old (Olson and others, 1977) syenitic rocks contain thorium in amounts above the crustal average of about $11 \mathrm{ppm}$ but not in exceptionally high amounts for syenitic rocks. Five samples of biotite melasyenite and one of leucosyenite had $\mathrm{eU}$ of 0.003-0.004 percent and uranium contents of less than 0.001 percent, suggesting thorium as the principal radioactive element. Three other samples were analyzed by gamma-ray spectrometry and found to con- tain $19.78,14.5$, and $18.3 \mathrm{ppm}$ thorium, respectively. The thorium content of the syenites and their proximity to some thorium veins suggest a possible relationship of some thorium veins to the syenites. A relationship of thorium veins to the 570-m.y.old rocks of the complex of Iron Hill, however, is more likely and is discussed in connection with those rocks.

Three pluglike bodies of intrusive breccia, discovered during mapping of the Carpenter Ridge quadrangle (Hedlund and Olson, 1973), are spatially and perhaps genetically related to the $1,400-\mathrm{m}$.y.-old mafic syenites. The largest body of intrusive breccia is elliptical in general plan and is about $900 \mathrm{~m}$ long and $240 \mathrm{~m}$ wide. The intrusive breccia consists of angular fragments of diverse Precambrian rocks set in a light-gray or pale-green groundmass of comminuted rock fragments, ankerite or dolomite, and opaque minerals. Parts of these bodies of intrusive breccia have radioactivities of two to three times the background of the surrounding quartz-mica schist, and the one sample analyzed by gamma ray spectrometry contains $38 \mathrm{ppm}$ thorium. Three semiquantitative spectrographic analyses showed (in percent) barium and strontium generally about 0.15 , zirconium $0.03-0.07$, cerium 0.03 , lanthanum 0.015 , neodymium $0.015-0.03$, yttrium $0.003-0.015$, niobium 0.007 , and vanadium $0.015-0.03$ (Hedlund and Olson, 1980, table 1). These concentrations are several times the crustal averages for these elements.

\section{UPPER PROTEROZOIC OR LOWER PALEOZOIC IGNEOUS ROCKS}

Rocks of Late Proterozoic or Cambrian age comprise the complex of Iron Hill; related outlying dikes of trachyte, carbonatite, nepheline syenite, pyroxenite, melasyenite, and lamprophyre; thorium-bearing veins; and diabase dikes. The alkalic rocks of Iron Hill have been dated at about $570 \mathrm{~m} . y$. and the diabase dikes are somewhat younger, probably about $510 \mathrm{~m} . \mathrm{y}$. old (Olson and others, 1977).

The thorium concentrations in the district are probably all related to this episode of igneous activity. These concentrations include thorite veins, the Iron Hill carbonatite body, carbonatite dikes, trachyte dikes, magnetite-ilmenite-perovskite segregations, and the disseminated thorium-bearing minerals in small, anomalously radioactive plutons chiefly of granite or quartz syenite. The latter plutons are of uncertain age and may be older than the other deposits listed. The genetic relation of the thorium deposits to the $570-\mathrm{m}$.y.-old igneous activity is suggested by the suite of minor elements such as thorium, rare-earth 
TABLE 1.-Chemical analyses of Powderhorn Granite and fenite

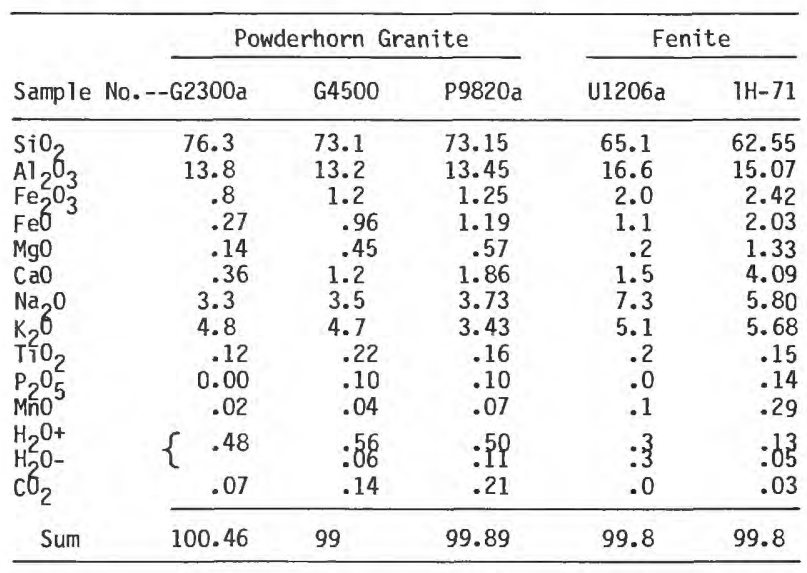

Sample descriptions

G2300a. Powderhorn Granite, medium grained, 1ight pink. NE1/4 sec 3, T. 47 N., R. $3 \mathrm{~W}$, at $8,680 \mathrm{ft}$ elevation, east side of gully, $110 \mathrm{~m}$ northwest of road fork marked 8694 . Analys is by P. L. D. Elmore and S. D. Botts.

G4500. Powderhorn Granite. NE1/4 sec. 8, T. 47 N., R. 3 W. Above road on east side of Lake Fork of Gunnison River. Analysis by N. G. Skinner.

P9820a. Powderhorn Granite, coarse grained, biotitic, pink perthitic microcline phenocrysts $2.5 \mathrm{~cm}$ across. SWI $/ 4 \mathrm{sec} .36$, T. 47 N., R. 2 W. At $9,320 \mathrm{ft}$ elevation, north side of Huntsman Gulch, in tributary gully northeast of spring. Analys is by E. L. Munson.

U1206a. Soda syenite (Larsen, 1942, p. 26), considered to be fenite. SW1/4 sec. 7, T. 46 N., R. 1 W. South of gully, near northwest base of hill above $9,000 \mathrm{ft}$ contour. Analysis by George Steiger.

IH-71. Fenite, gray, gneissic, medium grained, composed chiefly of microcline perthite and elongate, alined aggregates of aegirine-augite grains. NE1/4 sec. 12 , T. $46 \mathrm{~N} ., R_{0} 11 / 2 \mathrm{~W}$. Analysis by E. L. Munson.

elements, niobium, titanium, barium, and strontium characteristic of the rocks and deposits; the alkali metasomatism (fenitization) of the wall rocks adjacent to the thorium-bearing veins and the alkalic rock complex; and the fact that veins as well as alkalic rocks are cut by diabase dikes. Furthermore, the veins and the trachyte dikes are characterized by a fetid odor that is also found in places in the fenite surrounding the alkalic complex. Such a fetid odor has been described in other areas where thorium concentrations are related to alkalic rocks (e.g. Olson and others, 1954; Heinrich and Anderson, 1965).

Although the alkalic rock complex occupies $31 \mathrm{~km}^{2}$, thorium-bearing veins are present in at least a $650-\mathrm{km}^{2}$ area (fig. 1). They have been found from the Black Canyon of the Gunnison River southeastward to Cochetopa Creek and Razor Creek.

\section{ALKALIC ROCK COMPLEX OF IRON HILL}

The complex of Iron Hill is the best example of the carbonatite-alkalic rock association in the United States and is one of the outstanding occurrences in the world, comparable to many of the classic areas in Africa and other continents. This heterogeneous assemblage of alkalic igneous rocks was intruded, probably from a source in the mantle, about $570 \mathrm{~m} . y$. ago. The complex of Iron Hill lacks a clearly defined ring or cone sheet structure typical of some of the African complexes, but it has a radial carbonatite dike system that partly surrounds an eccentrically placed carbonatite stock. This stock was emplaced as a carbonatitic magma, and it is suggested that forcible emplacement was accompanied by radial fracturing of the surrounding pyroxenite. The depth of the complex below the surface at the time of intrusion is not known. Possibly the complex breached the surface, but erosion during long periods of Paleozoic, Mesozoic, and Cenozoic time has removed the upper part.

The alkalic rock complex of Iron Hill occupies an elliptical area (fig. 3) of about $31 \mathrm{~km}^{2}$ along the east side of Cebolla Creek. The complex is about $10 \mathrm{~km}$ long, has a maximum width of about $5 \mathrm{~km}$, and the long axis strikes $\mathrm{N} 55^{\circ}-60^{\circ} \mathrm{W}$. The dolomitic carbonatite (rauhaugite) stock that forms Iron Hill is also elliptical in outcrop, the long axis striking northwest.

The alkaline complex forms a distinctive topography that is largely controlled by lithology and climate. In this semiarid region the carbonatite of Iron Hill is

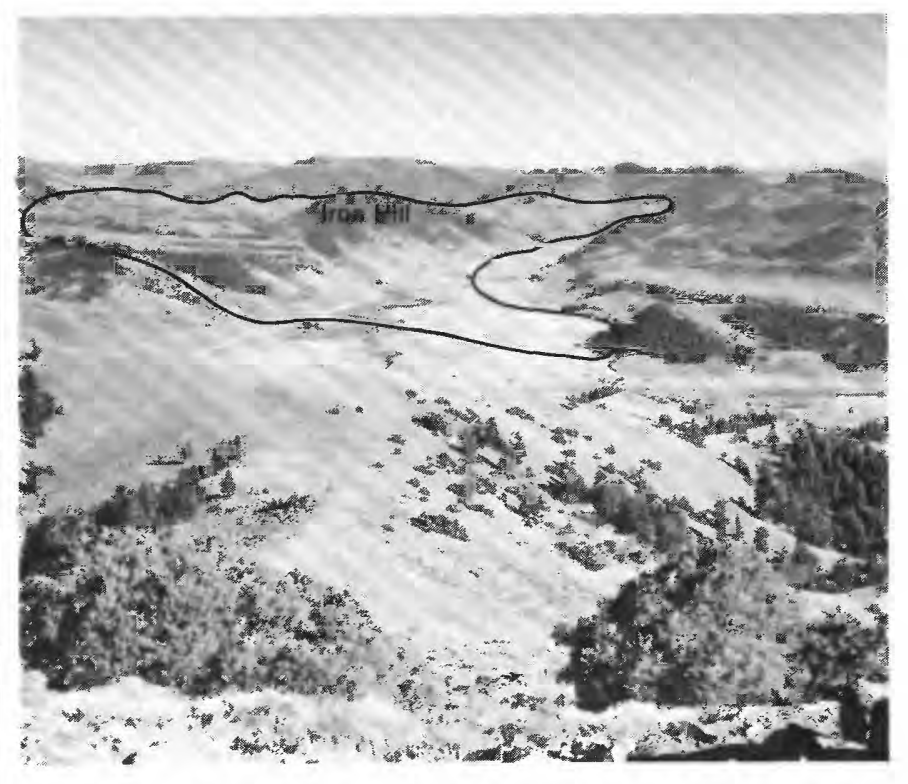

FIGURE 3.-View southeastward of Cebolla Creek valley and Iron Hill. Approximate outline of the complex of Iron Hill is indicated by the line. 
more resistant to weathering than the surrounding basic alkaline rocks; hence the carbonatite forms a hill surrounded by a horseshoe-shaped depression of low relief. Older Precambrian granite forms an outer, arcuate ridge about the inner outcrop belt of basic alkalic rocks.

The rocks in the complex (fig. 4) from oldest to youngest are pyroxenite, uncompahgrite, ijolite, nepheline syenite, and carbonatite; the last two rock types locally show overlapping age relations. Magnetite-ilmenite-perovskite dikes and segregations are chiefly confined to the pyroxenite. Fenite occurs commonly at the borders of the complex. Carbonatite dikes radiate outward from the dolomitic carbonatite stock and cut all the other rock types of the complex.

The distribution of radioactivity in the alkalic rocks of Iron Hill was studied by taking 1,258 random scintillation-counter readings distributed among the various rock types approximately in proportion to their area. These readings, which were made on the outcrop with a scintillation counter, are given in the description of the various rock types that follow. The total radioactivity of the alkalic rocks is well above that of the surrounding Powderhorn Granite and metamorphic rocks that commonly show a background count of $0.02-0.025 \mathrm{mr} / \mathrm{hr}$ (milliroentgens per hour). The radioactivity of pyroxenite, uncompahgrite, ijolite, and nepheline syenite, which, combined make up more than 80 percent of the complex, is fairly uniformly distributed among the rock types and averages about $0.035 \mathrm{mr} / \mathrm{hr}$ or about $1 \frac{1}{2}$ times that of the surrounding granite.

Within the complex, carbonatite is the most radioactive rock. The carbonatite stock averages $0.055 \mathrm{mr} / \mathrm{hr}$ for 226 readings, or more than twice the background of typical Powderhorn Granite. Carbonatite dikes vary considerably in their radioactivity from one dike to another and within individual dikes, hence a representative average figure was difficult to obtain. On the average, however, they are somewhat more radioactive than the carbonatite stock. Furthermore, the radioactivity of pyroxenite increases markedly in those areas where the pyroxenite is permeated by many small dikes and seams of carbonatite, including the mixed rock zone near the carbonatite stock.

\section{FENITE}

Fenite occurs in a zone, in places more than $0.6 \mathrm{~km}$ wide, around a large part of the margin of the complex. It is a syenitic rock formed from various country rocks, chiefly granite and felsite, by metasomatic alteration associated with the intrusion of alkalic or carbonatitic magmatic fluids. The fenite zone is generally wider along the south margin of the complex and is present but narrower along the north side. Although the fenite may not have all formed at one time, it is cut by and apparently predates some dikes and apophyses of the pyroxenite. In places the fenite is intruded by dikes of nepheline syenite, carbonatite, and by diabase. The fenite is essentially the same as the "soda syenite" described by Larsen $(1942$, p. 25-26).

The most abundant fenite in the Powderhorn area is gray, is medium to coarse grained, and contains lenticular aggregates of aegirine-augite that impart a schlieric texture to the fenite (fig. 5). The highly perthitic microcline grains are anhedral to euhedral and commonly have dusty inclusions of ferric oxides and thin, marginal selvages of fine-grained albite. Accessory minerals include calcite, muscovite, apatite, and sphene.

The gradation from granite country rock to fenite is characterized by the following changes: the microcline phenocrysts become grayer rather than red, more perthitic, less euhedral, and the porphyritic texture of the granite becomes less conspicuous. The quartz content diminishes, aegirine-augite replaces the biotite, and a gneissic or schlieric texture may develop or intensify. In advanced stages the fenite probably became rheomorphic locally, as suggested by the schlieric texture. Fracture fillings of blue-green sodic amphiboles, such as riebeckite(?) and richterite, and sodic pyroxenes are common in granite or felsite in places in the fenite zone. These represent a less intense form of fenitization and may be found as much as several kilometers from the complex. Some veinlets of sodic amphibole have slightly anomalous radioactivity due to thorium.

Fenite varies with the type of original country rock. Fenite derived from hornblende gneiss is likely to be rich in sodic pyroxene. Generally the felsitic rocks northwest of the complex, which are siliceous metavolcanic rocks such as metarhyolite, show less conspicious fenitization than other rocks close to margins. Fenite is present, however, in felsite at the northwest end of the complex, for example at a point $1 \mathrm{~km}$ north of the Powderhorn store. Here the schistose felsite near the contact with pyroxenite has been albitized, and the normally gray, fine-grained felsite grades into white, medium-grained, equigranular, albite-rich rock containing sparse wispy clots of biotite. The microcline has been albitized, and vein, patch, and string perthite is abundant.

Table 1 illustrates the chemical changes that occur as granite is altered to fenite near the alkalic complex. Two analyses of Powderhorn Granite from the Gateview quadrangle and one from about $1.1 \mathrm{~km}$ north of 


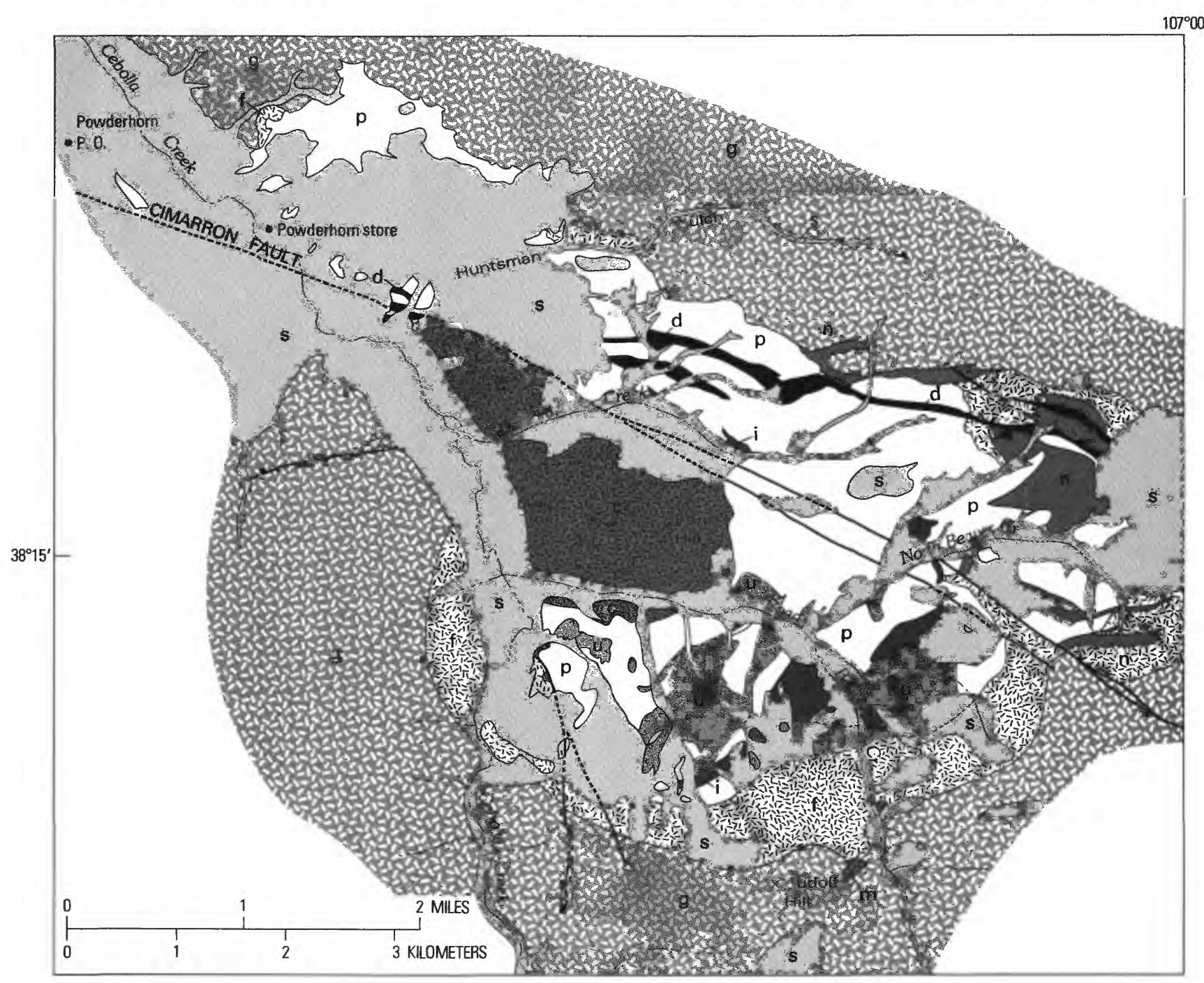

\section{EXPLANATION}

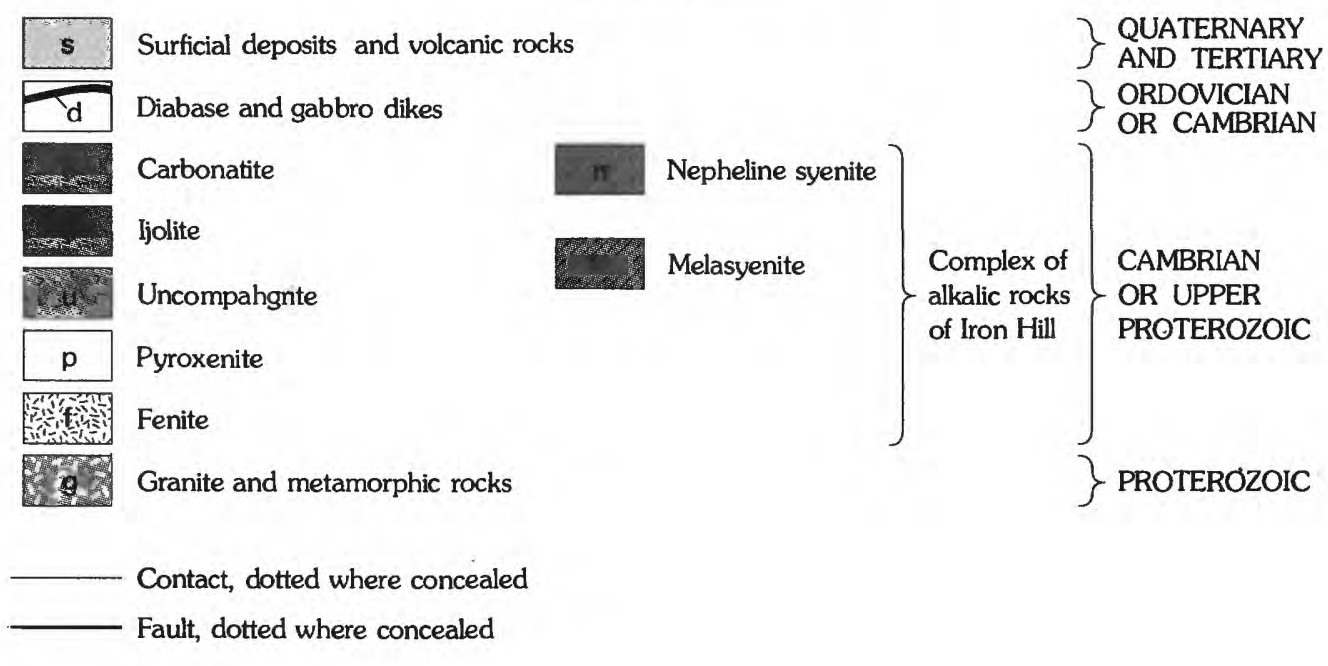

FIGURE 4.-Generalized geologic map of the complex of alkalic rocks at Iron Hill, Powderhorn district. 
the pyroxenite contact are representative of the Powderhorn Granite. Development of fenite from the granite involves a loss of silica and a gain of alkalies, iron, and alumina.

Fenite was developed near several of the rock types of the complex and probably formed at different times in several places. It was formed, for example, extensively near pyroxenite and uncompahgrite of the complex, near isolated bodies of carbonatite outside the complex, and near the nepheline syenite stock and dikes at the east end of the complex.

\section{PYROXENITE}

Pyroxenite underlies about 70 percent of the outcrop area in the complex of Iron Hill and is about $10 \mathrm{~km}$ in maximum dimension. It is locally capped by remnants of Oligocene ash-flow tuffs and Quaternary and Tertiary fan deposits. The pyroxenite weathers readily, forming a terrane of low relief between the surrounding hills of Precambrian granite and felsite and the resistant Iron Hill carbonatite stock.

The pyroxenite has steep, sharp, discordant contacts with the surrounding Precambrian granite and felsite. A few apophyses and dikes of pyroxenite locally extend into the country rocks. Most of the pyroxenite is medium grained and equigranular. Generally the pyroxenite lacks a fine-grained, chilled border facies and shows medium- to coarse-grained texture near the

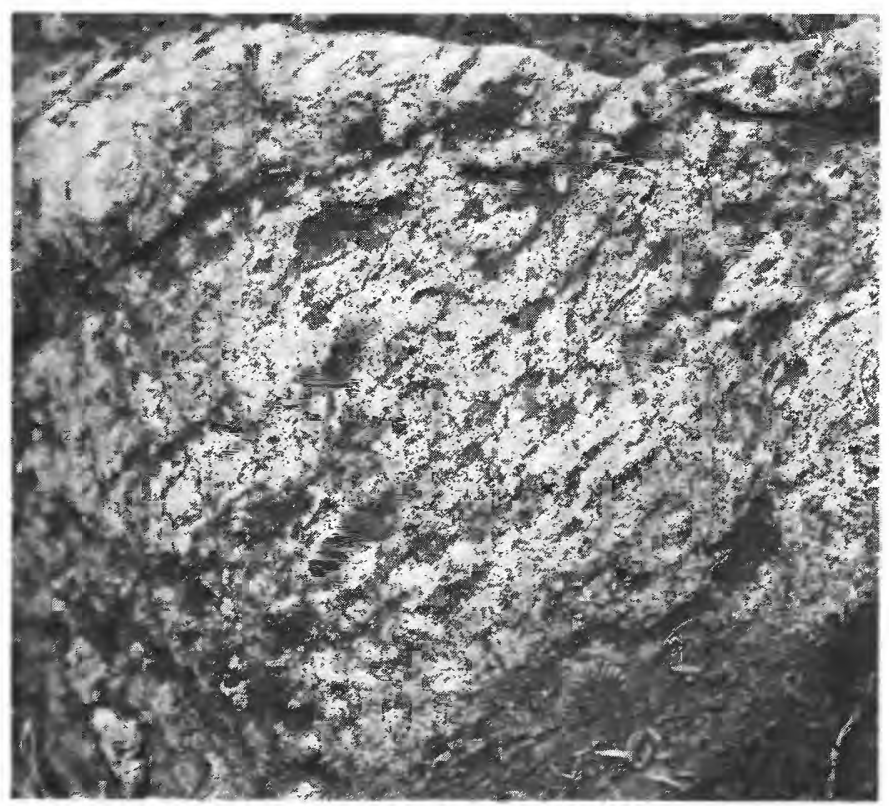

FIGURE 5.-Fenitized granite, with schlieric texture; northeast margin of the complex of Iron Hill. Lenticular clots of aegirine augite are dark. Microcline perthite is the dominant leucocratic mineral. Width of rock shown is about $1 \mathrm{~m}$. contact with the country rocks, indicating that the wall-rock temperature was close to that of the intrusive magma. Primary internal structures within the pyroxenite consist locally of a strong layering, coarsegrained pyroxene-rich layers alternating with biotiteor vermiculite-rich layers. The pyroxenite is locally cut by numerous dikes and veins consisting of vermiculite and apatite or of magnetite. In some pegmatitic, vermiculite-rich dikes the vermiculite plates are coarsest where the intergrown pyroxene also coarsens. Prismatic diopside crystals as much as $15 \mathrm{~cm}$ (centimeters) long in the dikes have their $\mathrm{c}$ axes alined perpendicular to the walls of the dikes. Some thin vermiculite-diopside dikes are zoned. Coarse vermiculite plates are near and roughly perpendicular to the walls, whereas the core of the dike consists of decussate, fine-grained vermiculite intergrown with fine-grained diopside and magnetite.

The heterogeneity of the internal structures within the pyroxenite suggests that it was a multiple intrusion. Dilatant fractures in the earlier crystallized pyroxenite were filled with younger fractions of the magma, and considerable replacement of early formed minerals occurred in the later magmatic and deuteric stages. Secondary internal structures are chiefly due to shearing. Light gray, fine grained stringers and veinlets of calcite and biotite locally pervade the pyroxenite along shear zones and cut across the primary structures of the pyroxenite. Where subparallel, the micaceous shear planes resemble primary layering in the pyroxenite (fig. 6). The micaceous shear planes generally strike N. $60^{\circ}-70^{\circ} \mathrm{E}$. and $\mathrm{N} .60^{\circ}-70^{\circ} \mathrm{W}$. and dip $70^{\circ}-80^{\circ} \mathrm{N}$. This orientation approximates that of the carbonatite dikes in the complex; hence the shear-

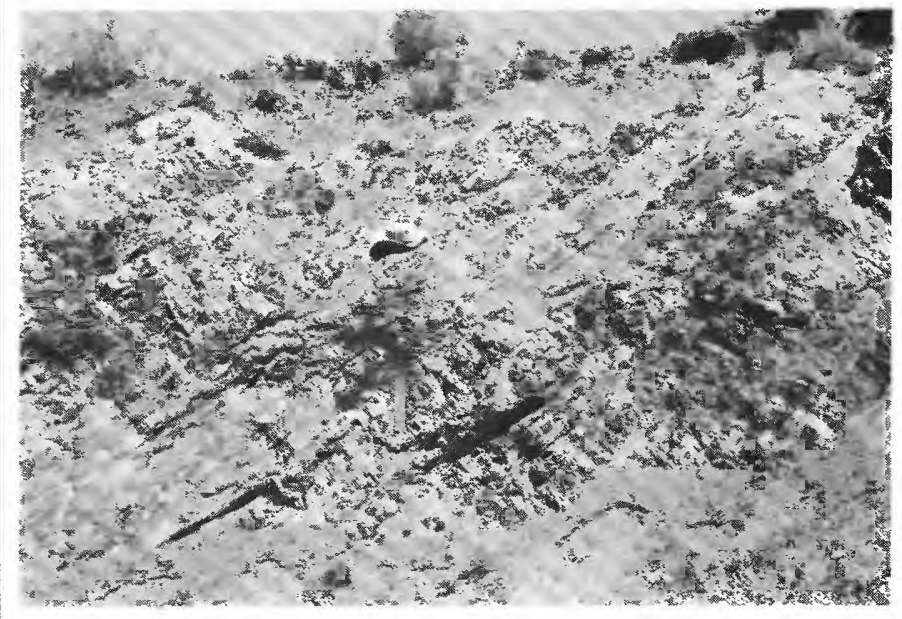

FIGURE 6.-Series of parallel micaceous shear planes in pyroxenite. Many of the micaceous shears follow joints and cut pre-existing structures in the pyroxenite. 
ing may have been related to the period of carbonatite intrusion. This relation also is suggested by the high carbonate content in the shear planes.

Several textural varieties occur in pyroxenite and include (1) pegmatitic, typically developed in coarsegrained clinopyroxene-biotite rock; (2) fine-to coarsegrained hypidiomorphic, shown by pyroxenite that contains euhedral pyroxene, sphene, and melanite with anhedral interstitial magnetite and ilmenite; (3) poikilitic, shown by inclusions of sphene in melanite, perovskite in magnetite, and diopside in melilite; (4) schlieric, shown by lenticular aggregates of melanite or magnetite in the pyroxenite; (5) brecciated, shown by fractures in brecciated pyroxenite filled by nepheline syenite, at the east end of the complex.

The pyroxenite is composed chiefly of diopsidic augite, biotite, magnetite, melanite, sphene, apatite, and perovskite. Proportions of these minerals vary considerably, making it difficult to assess the average mineral composition. About 94 modal analyses were made of the pyroxenite. These values were plotted on volume percent-frequency curves (fig. 7). In thin section the following minerals were observed: pyroxene (chiefly diopsidic augite), magnetite, ilmenite, perovskite, leucoxene, melanite, sphene, phlogopite, vermiculite, biotite, apatite, pyrite, chalcopyrite, pyrrhotite, orthoclase, brown amphibole, chlorite, sodic amphibole, idocrase, calcite, sericite, quartz, and hematite.

Pyroxene and its alteration products make up as much as 92 percent of the rock but commonly constitute 55 to 70 percent by volume. The pyroxene varies in different rocks of the complex; it is mostly augite but includes also diopside, aegirine-augite, and aegirine (Larsen, 1942, p. 47). The pyroxene shows a wide range in crystal size from very fine grained augite to grains of diopside as much as $15 \mathrm{~cm}$ long. Much of the augite of the pyroxenite has moderate pleochroism: green to yellowish green; $\mathrm{Z}$ to $\mathrm{c}, 40^{\circ}-45^{\circ} ; 2 \mathrm{~V}, 60^{\circ}-70^{\circ}$; $\mathrm{Nx}, 1.68-1.72, \mathrm{Ny}, 1.69-1.73, \mathrm{Nz}, 1.71-1.75$. Some grains are replaced along their margins by brown amphibole, biotite (fig. $8 A$ ), magnetite, chlorite, sodic amphibole, and calcite; such replacement is sporadic and is most intense near carbonatite bodies or dikes. Spectrographic analyses of two diopside samples are shown in table 2.

Amphiboles are present in amounts of as much as 5 percent. The amphibole is quite variable in composition (Larsen, 1942, p. 48-52) but commonly is dark brown to black and has moderate pleochroism light brown to greenish brown. The common variety in the pyroxenite was considered to be hastingsite by Larsen $(1942$, p. 52). It commonly mantles or replaces the pyroxene.
Melanite is present in many of the thin sections of pyroxenite to a maximum of about 25 percent by volume. The melanite is isotropic and is zoned; lighter brown zones alternate with darker brown. The melanite is anhedral to euhedral and is commonly poikilitic; inclusions of sphene (fig. $8 H$ ) and perovskite (fig. $8 D$ ) are common. Some melanite forms thin mantles about pyroxene and magnetite-ilmenite grains. The index of refraction ranges from 1.85 to 1.98 and is commonly about 1.88 . The specific gravity is $3.71 \pm 0.05$. The unit cell is $12.051 \pm 0.002$ angstroms. Spectrographic analysis of one melanite sample is shown in table 2.

Magnetite and ilmenite are ubiquitous in the pyroxenite as dikes, veins, and segregations, and as discrete grains intergrown with melanite and other silicates. Discrete grains of magnetite and ilmenite constitute as much as $\mathbf{4 0}$ percent of the pyroxenite but commonly range from 10 to 15 percent by volume. They are commonly intergrown with each other and with perovskite to form composite grains. Some of the ilmenite forms bladed, exsolution-type intergrowths along the (111) direction in the magnetite. Spectrographic analysis of one magnetite sample from pyroxenite is shown in table 2.

Perovskite is present in about 53 percent of the thin sections of pyroxenite, making up as much as 20 percent by volume. The amounts of perovskite and magnetite tend to correlate with one another and are comparable in most rocks. Larsen (1942, p. 36) estimated the perovskite to make up about 7 percent of the pyroxenite and 6 percent of the entire complex, and magnetite 11 percent of the pyroxenite and 10 percent of the entire complex. The perovskite commonly occurs as euhedral crystals intergrown with magnetite and ilmenite but also occurs as discrete grains. The perovskite is dusky purple, slightly anisotropic, and has complex penetration twinning. Semiquantitative spectrographic analyses of two perovskite samples are shown in table 2.

Leucoxene is present in 28 percent of the thin sections, as an alteration product of perovskite, and composes as much as 18 percent by volume of the pyroxenite.

Sphene is present in about 34 percent of the thin sections of pyroxenite and constitutes a maximum of about 19 percent by volume of the rock. The sphene commonly occurs as relatively coarse, dark, honeycolored euhedral crystals with excellent twinning. The sphene occurs as inclusions in melanite (fig. $8 H$ ), as discrete grains intergrown with silicates, and as aggregated crystals associated with magnetite. Sphenebearing pyroxenite is most common on the ridge in the $\mathrm{NE}^{1 / 4}$ sec. 2, T. 46 N., R. $2 \mathrm{~W}$. 

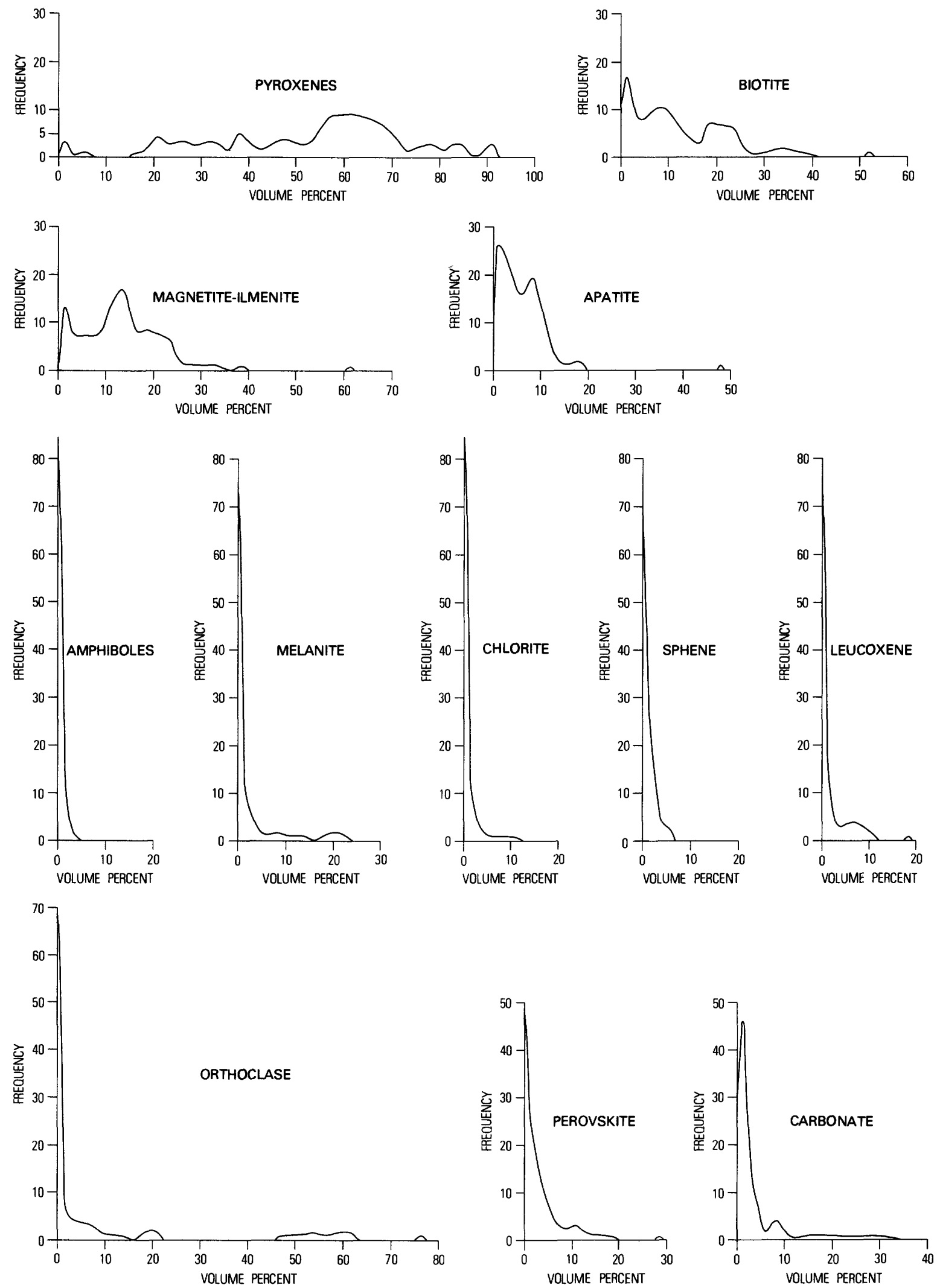

FIGURE 7.-Graphs showing percentages of principal minerals in 94 modal analyses of altered pyroxenite. Frequency is the percentage of thin sections that have the determined volume percent of a mineral. Low values for pyroxenes in some thin sections indicate degree of alteration or presence of variants related to the pyroxenite body but not strictly classifiable as pyroxenite. Minor accessory minerals include pyrite, chalcopyrite, pyrrhotite, sericite, quartz, zoisite, limonite, barite, and idocrase. 
TABLE 2.-Semiquantitative spectrographic analyses of melanite, diopside, perovskite, and magnetite from pyroxenite, complex of Iron Hill

[Analysts: J. C. Hamilton, and R. G. Havens. 〉, greater than; 〈, less than; leaders (-), analyses did not show any elements in these concentrations]

\begin{tabular}{|c|c|c|c|c|c|c|}
\hline \multicolumn{2}{|c|}{ Sample No.-- P8085a } & P301 & P8811 & $\mathrm{P} 8326$ & P8326a & P8922 \\
\hline $\begin{array}{l}\text { Amount } \\
\text { (percent) }\end{array}$ & Melanite & Diopside & Diopside & Perovskite & Perovskite & Magnetite \\
\hline$>10$ & $\begin{array}{l}\text { Si, } \mathrm{Fe} \text {, } \\
\mathrm{Ca}\end{array}$ & $\begin{array}{l}\mathrm{Si}, \mathrm{Fe}, \\
\mathrm{Ca}\end{array}$ & $\begin{array}{l}\mathrm{Si}, \mathrm{Fe}, \\
\mathrm{Mg}, \mathrm{Ca}\end{array}$ & $\mathrm{Ca}, \mathrm{Ti}$ & $\mathrm{Ca}, \mathrm{Ti}$ & Fe, Ti \\
\hline 7 & --- & $\mathrm{Mg}$ & --- & $\cdots$ & -- & $\cdots$ \\
\hline 5 & --- & $\ldots$ & -- & $\cdots$ & -- & $\mathrm{Mg}$ \\
\hline 3 & --- & $\mathrm{Na}$ & -- & $\mathrm{Fe}, \mathrm{Mg}$ & $\mathrm{Fe}$ & -- \\
\hline 2 & --- & --- & --- &.-- & -- & $\mathrm{Ca}$ \\
\hline 1.5 & Al & -.. & --- & $\mathrm{Ce}$ & $\mathrm{Mg}, \mathrm{Ce}$ & Al \\
\hline 1 & $\mathrm{Ti}$ & --- & --- & $-\ldots$ & -- & $\mathrm{K}$ \\
\hline .7 & $\mathrm{Mn}$ & -- & $\mathrm{Al}_{\mathrm{T}_{i}} \mathrm{Na}$, & La, Nd & La, Nd & $\cdots$ \\
\hline .5 & --- & Mn & --- & -- & --- & -- \\
\hline .3 & $\mathrm{Mg}$ & Al & -- & $\begin{array}{l}\mathrm{Si}, \mathrm{Al}, \\
\mathrm{Nb}, \mathrm{Sr}\end{array}$ & $\begin{array}{l}\mathrm{Si}, \mathrm{Al}, \\
\mathrm{Nb}, \mathrm{Sr}\end{array}$ & Si, Mn \\
\hline .2 & v & -.- & $\mathrm{Mn}$ & -- & --- & $\cdots$ \\
\hline .15 & $\mathrm{Na}$ & --- & -.. & $\mathrm{Mn}, \mathrm{Pr}$ & $\mathrm{Mn}, \mathrm{Pr}$ & In \\
\hline .1 & $\mathrm{Ba}, \mathrm{Sr}$ & $\mathrm{Ti}, \mathrm{Ba}$ & $\mathrm{Sr}$ & -- & -- & $\mathrm{Na}, \mathrm{V}$ \\
\hline .07 & $\mathrm{r}, \mathrm{Zr}, \mathrm{Nd}$ & $\mathrm{Sr}, \mathrm{V}$ & --- & Sm & $\mathrm{Sm}$ & $\cdots$ \\
\hline .05 & --- & --- & v & -- & -- & $\mathrm{Ce}$ \\
\hline .03 & -- & --- & 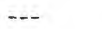 & V, Y, Zr & $V, Y, \mathrm{Zr}$ & $\mathrm{La}, \mathrm{Nd}$ \\
\hline .02 & La & -- & -- & -- & --- & \\
\hline .015 & -- & $\overline{7}--$ & Zr & $\mathrm{Ba}$ & $\mathrm{Ba}$ & -- \\
\hline .01 & -- & $\mathrm{Zr}$ & -- & -- & -- & $\begin{array}{l}\text { Ba, } \mathrm{Nb} \text {, } \\
\mathrm{Sr}\end{array}$ \\
\hline .007 & $-\cdot$ & $\mathrm{Cu}$ & $\mathrm{Cu}$ & $\mathrm{Cu}$ & $\mathrm{Cu}$ & $\mathrm{Ni}, \mathrm{Zr}$ \\
\hline .005 & -- & Co & $\mathrm{Ba}$ & --- & --- & $\mathrm{Cu}$ \\
\hline .003 & -- & La & Co & $\mathrm{Pb}$ & $\mathrm{Pb}$ & $\cdots$ \\
\hline .002 & --- & --- & $\mathrm{Pb}, \mathrm{Sc}$ & --- & $\cdots$ & Mo \\
\hline .0015 & $\mathrm{Cr}$ & Sc, Y & Y & $\mathrm{Yb}$ & Yb & $\cdots$ \\
\hline .001 & Sc & -- & $\mathrm{Cr}$ & -- & $\cdots$ & -- \\
\hline .0007 & $\mathrm{Cu}$ & $\mathrm{Ni}$ & $\cdots$ & --- & -- & $\mathrm{Cr}$ \\
\hline .0003 & --- & $\mathrm{Be}$ & $\cdots$ & -- & -- & --- \\
\hline$<.05$ & $\mathrm{Ce}$ & $\mathrm{Ce}$ & $\mathrm{Ce}$ & -- & -- & -- \\
\hline$<.005$ & $\cdots$ & $\cdots$ & $\cdots$ & $\begin{array}{c}\text { Co, Dy, Er } \\
\text { Eu, Gd }\end{array}$ & $\begin{array}{c}r, C_{0}, \text { Dy, Er, } \\
\text { Eu, Gd }\end{array}$ & -- \\
\hline$<.002$ & $\mathrm{Ga}$ & $\mathrm{Ga}$ & $\mathrm{Ga}$ & --- & $\cdots$ & -- \\
\hline
\end{tabular}

Apatite is ubiquitous in pyroxenite and makes up as much as 48 percent by volume of the rock but is most commonly 5 to 10 percent. The apatite occurs as colorless to pale green prismatic grains, rarely as much as $5 \mathrm{~cm}$ long and $7 \mathrm{~mm}$ (millimeters) thick, commonly associated with magnetite (fig. $8 B, C$ ), phlogopite, biotite (fig. $8 B, C, D$ ), and vermiculite. Apatite inclusions occur in melanite (fig. $8 C, D$ ), orthoclase, pyroxene, and other minerals. The apatite is generally a fluorapatite with $\mathrm{N}_{\mathrm{o}}$ 1.63-1.64. Some grains of apatite enclose minute rutile(?) prisms alined along the $c$ axes of the apatite. The $\mathrm{P}_{2} \mathrm{O}_{5}$ content of the pyroxenite averages 1.3 percent in seven analyses weighted according to the proportions of the types present in the total pyroxenite mass (Larsen, 1942, p. 20).

Biotite ranges from 0 to 52 percent by volume of the pyroxenite and averages about 10 percent. The biotite is fine to coarse grained and is closely associated with magnetite (fig. $8 A, B$ ) in the more homogeneous varieties of pyroxenite. It is moderately to strongly pleochroic, dusky dark brown to pale yellowish brown, $\mathrm{Nz}$ 1.63. Vermiculite, a near-surface weathering product of biotite and phlogopite, is sporadically distributed in altered pyroxenite as segregations and in dikelike bodies (fig. 9). The vermiculite occurs in plates as much as $10 \mathrm{~cm}$ across and is commonly associated with coarse-grained diopside, apatite, and magnetite. Chlorite is present but not abundant in about 17 percent of the thin sections of pyroxenite, in amounts as much as 12 percent. It commonly replaces biotite or pyroxene and is most abundant where the pyroxenite has been altered adjacent to carbonatite dikes and veinlets.

Orthoclase and microcline are sporadically distributed but uncommon in the pyroxenite. Potassic feldspar is present in about 30 percent of the thin sections from the pyroxenite body, and the maximum amount is about 77 percent. The orthoclase is a late stage mineral that generally forms veins in the pyroxenite. It poikilitically encloses some pyroxene and apatite grains, and it shows varying degrees of alteration to sericite.

Calcite and dolomite generally average 2 to 5 percent by volume of the pyroxenite but may constitute as much as 35 percent. Some of the carbonate minerals that are considered primary are generally coarse grained and occur interstitially between grains of pyroxene, melanite, and magnetite, which show little or no alteration. Ocellar textures were not observed. Secondary carbonate minerals that are probably hydrothermal are generally associated with anastomosing carbonate veins or are adjacent to carbonatite dikes that cut the pyroxenite.

A melanite-orthoclase-apatite rock, characterized by abundant, euhedral melanite crystals, occurs in the pyroxenite in one place at the head of the north fork of Huntsman Gulch (NE $1 / 4 \mathrm{SW}^{1 / 4}$, sec. 35, T. $47 \mathrm{~N}$., R. $2 \mathrm{~W}$.). The melanite-orthoclase-apatite rock ranges from coarse to fine grained; in places the dark-brown, zoned melanite crystals are as much as $2 \mathrm{~cm}$ across and compose 75 percent of the rock. Between the melanite crystals, interstitial orthoclase makes up about 18 percent of the rock. Pale-green fluorapatite, composing about 5 percent of the rock, is intergrown with orthoclase and fills fractures in the melanite and orthoclase. Pyroxene in amounts of generally 1 percent or less occurs as inclusions in orthoclase and melanite and as clustered aggregates about the melanite grains. The accessory minerals include sphene and magnetite.

Pyroxenite is generally more radioactive than the surrounding Precambrian rocks because of its higher thorium content. It also is more radioactive than the mafic rocks of some other alkalic complexes, such as the mafic-ultramafic rocks in the northeastern part of the Middle Cambrian McClure Mountain Complex in the Wet Mountains. The pyroxenite of the complex of Iron Hill ranges from 0.01 to $0.08 \mathrm{mr} / \mathrm{hr}$ for 596 random readings with a scintillation counter, averaging 0.035 or about $1 \frac{1}{2}$ times the background of surrounding 

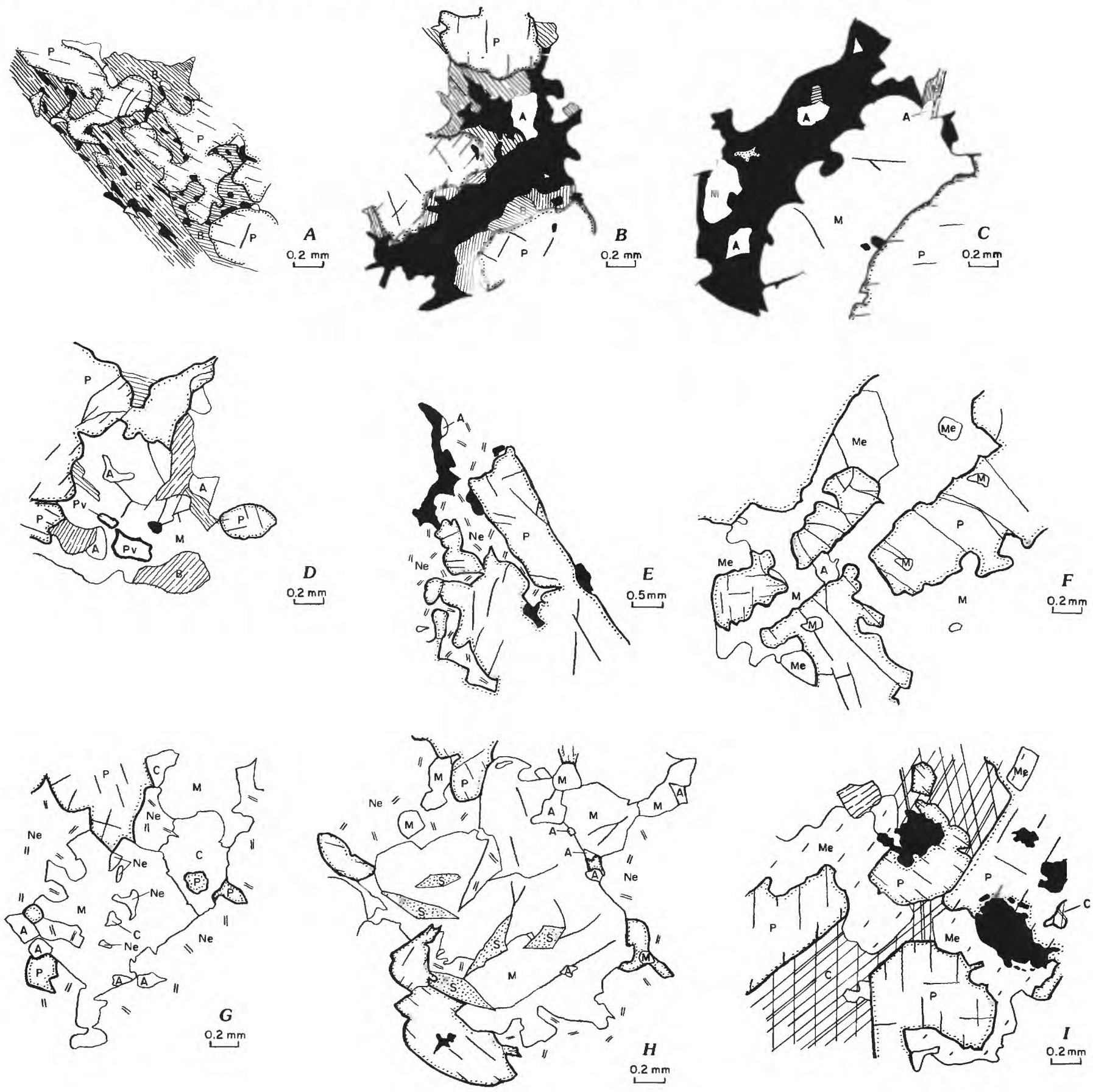

FIGURE 8.-Sketches of textures indicative of paragenetic sequence in pyroxenite, uncompahgrite, and ijolite. Minerals are A, apatite; B, biotite; C, calcite; M, melanite; Me, melilite; Ne, nepheline; $\mathrm{P}$, pyroxene; $\mathrm{Pv}$, perovskite; $\mathrm{S}$, sphene; black areas, magnetite-ilmenite. $A$, pyroxenite; biotite replacing diopside (P); abundant magnetite associated with the biotite. $B$, pyroxenite; biotite reaction rims around magnetite-ilmenite grains. $C$, pyroxenite; cusp-cary textures and veinlets of magnetite-ilmenite in apparently older melanite. $D$, pyroxenite; melanite interstitial and younger than pyroxene. $E$, ijolite; nepheline interstitial to and replacing pyroxene. $F$, uncompahgrite; melanite along intergrain boundaries of pyroxenes; melilite inclusion in melanite. $G$, ijolite; caries of nepheline in melanite; calcite replaces nepheline and pyroxene. $H$, ijolite; nepheline interstitial to melanite; sphene and apatite intergrown with and included in melanite. $I$, uncompahgrite; strongly twinned, primary calcite interstitial to pyroxene and melilite; melilite interstitial to pyroxene. 


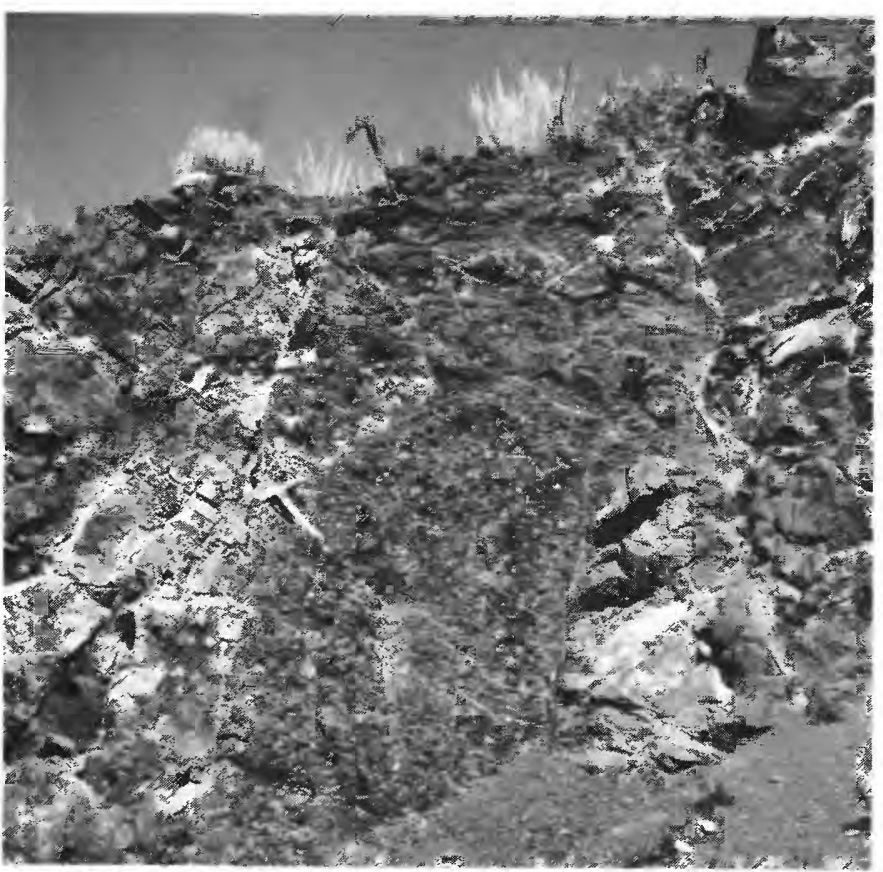

Figure 9.-Vermiculite-rich lens or dike in pyroxenite of the complex of Iron Hill. Coarse vermiculite plates are intergrown with sparse amounts of coarse diopside, magnetite, and green apatite.

Precambrian granite. Where carbonatite pervades the pyroxenite as small dikes, seams, and veinlets, the pyroxenite has a higher level of radioactivity. When such areas are added to the previous readings, the combined total of 775 random scintillation-counter readings averages $0.045 \mathrm{mr} / \mathrm{hr}$ or about twice the Precambrian granite background.

\section{MAGNETITE-ILMENITE-PEROVSKITE ROCK}

Dikelike bodies (fig. 10) and segregations of magnetite-ilmenite-perovskite rock constitute a small part of the complex of Iron Hill; they are most abundant in pyroxenite along a west-northwest-striking belt north of Deldorado Creek and at the northwest end of the complex. Most of the dikes are less than $60 \mathrm{~cm}$ thick and are traceable for less than $30 \mathrm{~m}$, but some are 25 to $45 \mathrm{~m}$ thick. One of the larger magnetiteilmenite-perovskite bodies, about $45 \mathrm{~m}$ thick, occurs about $300 \mathrm{~m}$ southeast of the Powderhorn store and strikes about $\mathrm{N} 15^{\circ} \mathrm{E}$. Its south end is covered by the alluvium of Cebolla Creek valley, and to the north it extends a short distance beneath the overlying Oligocene Sapinero Mesa Tuff.
The magnetite-ilmenite-perovskite rock commonly contains apatite and sparse biotite or phlogopite, augite, and idocrase. The magnetite and ilmenite occur in a granular intergrowth, as seen in polished sections, and some of the magnetite grains contain exsolution blades of ilmenite along (111) directions of the magnetite. The perovskite is very fine grained, generally less than $1 \mathrm{~mm}$ across, and occurs in variable amounts in the magnetite-ilmenite-pervoskite rock, locally constituting as much as $\mathbf{5 0}$ percent of the rock. The perovskite is commonly present as octahedra and less commonly as anhedral grains, and shows varying degrees of alteration to leucoxene. The perovskite is dusky purple, has complex penetration twinning, is weakly anisotropic, and has a low reflectivity and index of refraction of 2.34. Augite and phlogopite or biotite locally are present in isolated pods in the magnetite-ilmenite-perovskite rock.

A spectrographic analysis by J. C. Hamilton of magnetite from a magnetite-ilmenite-perovskite dike indicated iron as a major constituent, and amounts, in percent, of 3 calcium and titanium $\left(3.9\right.$ percent $\mathrm{TiO}_{2}$ by chemical analysis), 1.5 silicon and aluminum, 1 magnesium and potassium, 0.5 manganese, 0.3 sodium, 0.15 zinc and vanadium $\left(0.14\right.$ percent $\mathrm{V}_{2} \mathrm{O}_{5}$ by chemical analysis), and, in parts per million, 500 strontium, 200

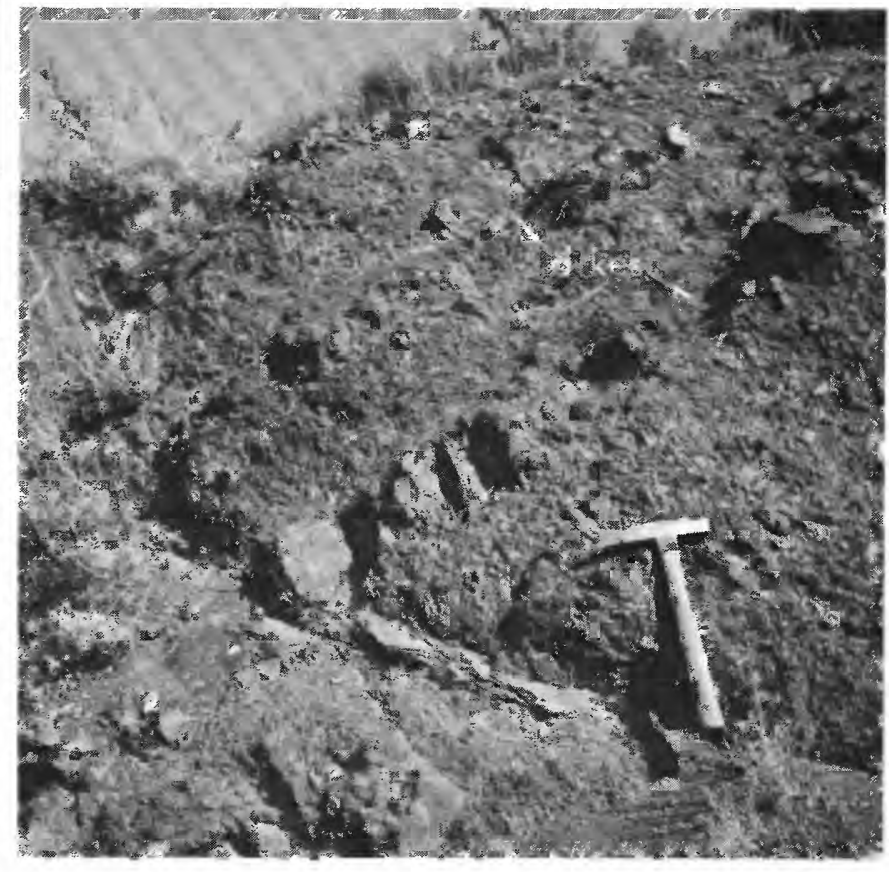

FIgure 10.-Two subparallel dikes of magnetite-ilmenite-perovskite rock cutting pyroxenite. 
cerium, 150 lanthanum, barium, and neodymium, 100 niobium, 70 copper and cobalt, 50 nickel and zirconium, 30 molybdenum, and 15 chromium.

The radioactivity of the magnetite-ilmeniteperovskite rocks at 128 localities ranges from 0.05 to $0.25 \mathrm{mr} / \mathrm{hr}$, or two to 12 times the background of typical Powderhorn Granite, and is attributable chiefly to thorium substitution for calcium in the perovskite. In two radiochemical analyses the perovskite contains 0.12 and 0.15 percent $\mathrm{ThO}_{2}$. In addition to thorium, rare earths are present in the perovskite, and niobium is present in amounts of $0.17,0.2$, and 0.7 percent in three semiquantitative spectrographic analyses of perovskite concentrates by E. L. Hufschmidt. Rare earths, like thorium, probably substitute for calcium in the perovskite and apatite, whereas niobium probably substitutes for titanium in the perovskite lattice. Because of the radioactivity of the perovskite and its common association with magnetite and ilmenite, radioactivity and magnetic surveys can give an approximate indication of perovskite concentration in the pyroxenite areas. Ground magnetic traverses show magnetic highs associated with many small magnetite concentrations in the pyroxenite, and belts of magnetic anomalies can be distinguished. The weathering of the magnetite-ilmenite-perovskite rocks and the pyroxenite, uncompahgrite, and ijolite has left numerous residual accumulations of granular magnetite.

Some of the magnetite and perovskite that is disseminated in the pyroxenite evidently coprecipitated with the silicate phases of the pyroxenite. The magnetiteilmenite-perovskite dikes and segregations, however, formed chiefly after or during the late stages of pyroxenite crystallization from iron-and titanium-enriched fluid. They are cut by nepheline syenite dikes, and at least one carbonatite dike about $12 \mathrm{~cm}$ thick cuts the magnetite-ilmenite-perovskite rock, which is reddened adjacent to the dike. Veins of phlogopite, chlorite, and carbonate mineral also cut the magnetite-ilmeniteperovskite rocks in places.

\section{UNCOMPAHGRITE}

Uncompahgrite forms irregular bodies and apophyses in the pyroxenite, chiefly south of Road Beaver Creek. The uncompahgrite is a light-gray, white-weathering, medium- to very coarse grained rock (fig. 11) composed of melilite and its alteration products, variable amounts of diopside (about 15 percent), and small amounts of magnetite, apatite, phlogopite, melanite, biotite, calcite, and perovskite. Texturally the uncompahgrite varies from poikilitic to hypidiomorphic granular. The melilite occurs both interstitial-

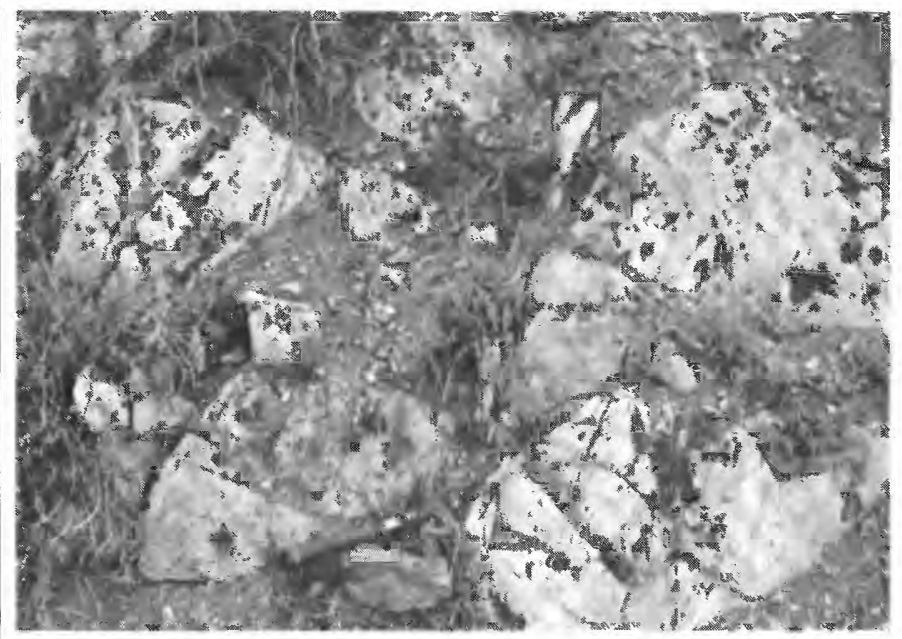

Figure 11.-Outcrop of uncompahgrite, composed chiefly of melilite and its alteration products (light colored); dark minerals are magnetite, pyroxene, and melanite.

ly between diopside grains (fig. $8 I$ ) and poikilitically enclosing diopside, magnetite, and apatite. Where the rock is pegmatitic the lustrous, smoky-gray melilite crystals are rarely as large as $50 \mathrm{~cm}$ in diameter. In thin section the fresh melilite commonly has a mosaic pattern with subindividuals of different optical orientation. The melilite is commonly uniaxial negative, $\mathrm{N}_{\mathrm{o}}$, 1.63 and $N_{e}, 1.62$. The cell dimensions of the tetragonal melilite are: a, $7.796 \mathrm{~A}$; and c, $5.038 \mathrm{~A} \pm 0.004 \mathrm{~A}$ with c/a, 0.646. Using the reference lattice spacings for the synthetic akermanite-gehlenite solid-solution series (Ervin and Osborn, 1949), the melilite contains about 70 percent akermanite. According to Nash (1972, p. 1368-1369), microprobe analyses of several melilite samples indicate they consist of roughly 50 percent sodium melilite and 50 percent akermanite.

In thin section, myrmekitic intergrowths of melanite and melilite are present but rare. Melanite also forms thin marginal selvages about diopside (fig. 12) in some varieties of the uncompahgrite. Biotite commonly mantles the magnetite.

The radioactivity of the uncompahgrite is generally high. Random readings with scintillation counter at 93 places showed a range of $0.01-0.1 \mathrm{mr} / \mathrm{hr}$, averaging 0.033 or about $1 \frac{1}{2}$ times the background of surrounding Precambrian granite.

\section{IJOLITE}

Several small bodies of ijolite in the pyroxenite and uncompahgrite form an arcuate zone suggestive of a ring dike. Contacts of ijolite with pyroxenite are commonly gradational. The ijolite is a mafic nephelinepyroxene rock (fig. $8 E, G, H$ ) consisting of nepheline, 


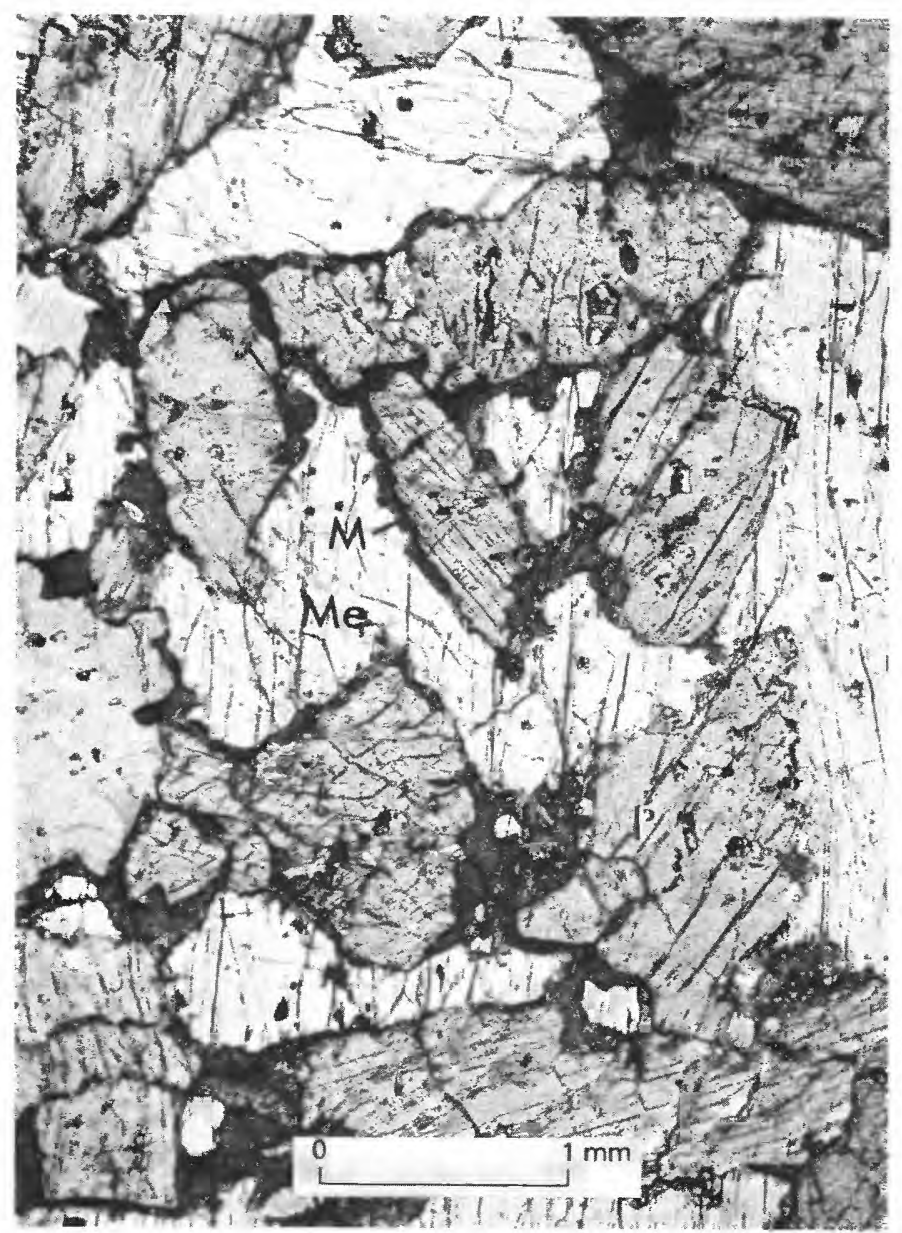

FIGURE 12.-Uncompahgrite, complex of Iron Hill. Melanite (M) rims on diopside $(\mathrm{P})$ with interstitial melilite (Me).

aegirine-augite, melanite, and accessory calcite, apatite, magnetite, ilmenite, and sphene. The nepheline content varies, and locally the ijolite grades into urtite containing about 80 percent nepheline. In most of the rock the nepheline is altered to very fine-grained sericite, cancrinite, natrolite, and analcite, chiefly along fractures and grain boundaries of the nepheline. The ijolite is fine to coarse grained and hypidiomorphic granular in texture. Locally, small pyroxene-rich layers 2 to $5 \mathrm{~cm}$ thick alternate with nepheline-rich layers. This layering is discontinuous and does not appear to reflect the shape of the intrusion.

The radioactivity readings at 25 points in ijolite range from 0.01 to $0.06 \mathrm{mr} / \mathrm{hr}$, averaging 0.033 or nearly the same as pyroxenite, uncompahgrite, and nepheline syenite. High radioactivity was found on the hill of ijolite just north of North Beaver Creek, $2.3 \mathrm{~km}$ east of Iron Hill, but is associated mainly with small carbonatite dikes that cut ijolite and pyroxenite near their contact.

\section{NEPHELINE SYENITE}

Nepheline syenite intricately intrudes granite, fenite, and pyroxenite near the eastern end of the complex of Iron Hill. In the vicinity of the nepheline syenite stock and dikes, the fenite aureole is more extensively developed than at other places along the north side of the complex. Immediately south of the nepheline syenite stock, the pyroxenite is brecciated and veined by nepheline syenite to form a mixed pyroxenite-syenite rock. The nepheline syenite is cut by carbonatite and diabase dikes.

The nepheline syenite is light gray, weathers pinkish gray, and is medium to coarse grained. Orthoclase microperthite laths compose about 75 percent of the nepheline syenite and locally impart a strong trachytic texture to the rock (fig. 13). Aegirine-augite, melanite, nepheline, and the alteration products of nepheline

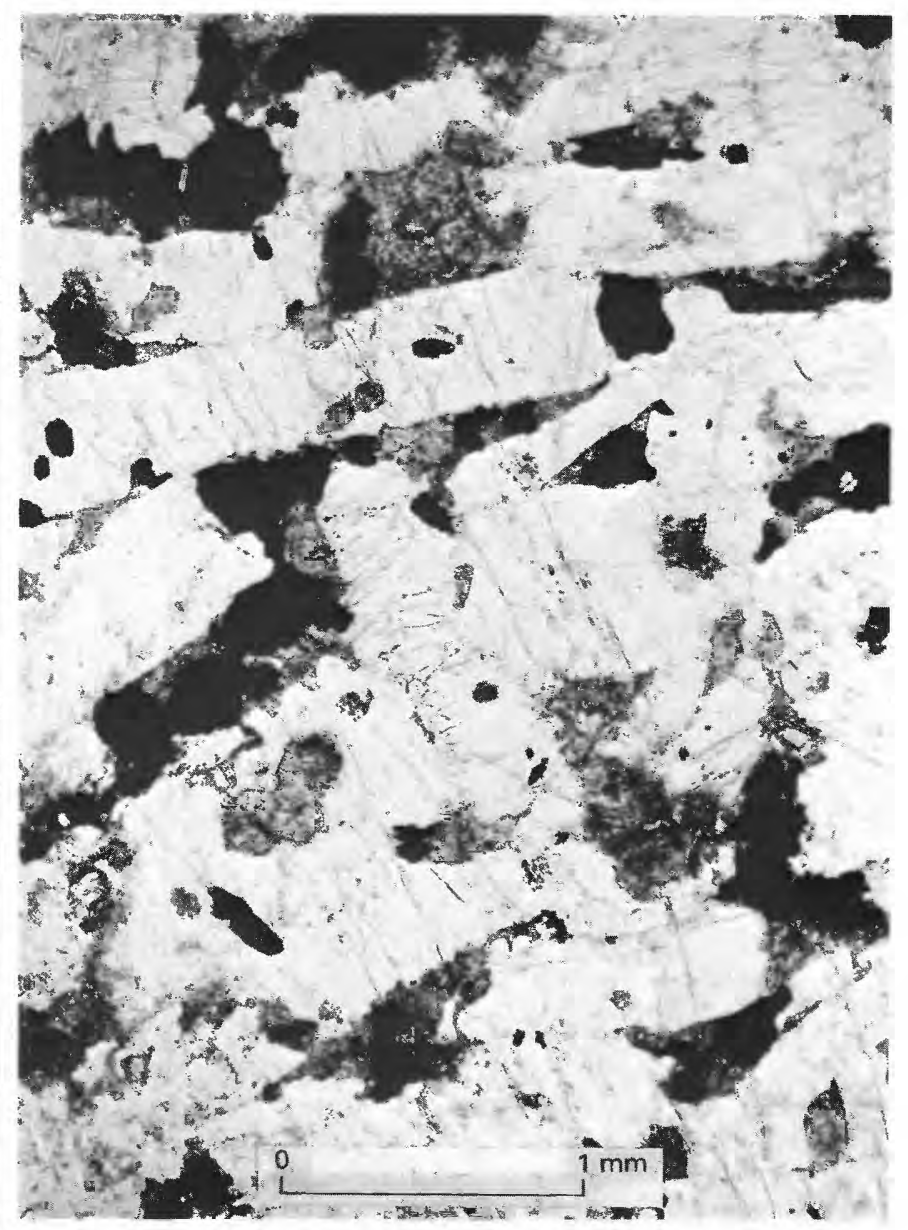

Figure 13.-Nepheline syenite, complex of Iron Hill, composed chiefly of lath-shaped microcline perthite (white). Melanite (black), aegirine-augite, and altered nepheline occur interstitially to the microcline laths. 
make up much of the remainder of the rock. Accessory minerals include magnetite, sphene, apatite, muscovite, calcite, and an unidentified zeolite. The orthoclase microperthite is Carlsbad twinned and shows string and patch perthite. The aegirine-augite, composing about 5 percent of the rock, is deep bluish green and weakly pleochroic; $\mathrm{Z} \mathrm{c}, 14^{\circ}$ and $\mathrm{Nz}, 1.76 ; \mathrm{Nx}, 1.73 ; 2 \mathrm{~V}$ is large. In some of the nepheline syenite dikes, aegirine-augite crystals are oriented perpendicular to the walls of the dike. Nepheline is largely altered to a mixture of muscovite, calcite, natrolite, and cancrinite. The nepheline and its alteration products are interstitial to the orthoclase and make up about 10 percent of the rock. The brown melanite is weakly zoned and commonly has inclusions of aegirine-augite, sphene, and apatite.

The nepheline syenite has a radioactivity that averages about $1 \frac{1}{2}$ times the background reading of the Precambrian granite surrounding the complex. A range of $0.02-0.08 \mathrm{mr} / \mathrm{hr}$, averaging 0.035 , was obtained in 39 random readings in nepheline syenite with a scintillation counter.

At the east end of the complex, near the head of North Beaver Creek in sections 7 and 12, the pyroxenite is brecciated and cut by thin fracture fillings and small dikelike bodies of nepheline syenite (fig. 14) to form a mixed rock. Nepheline syenite forms a small, irregular stock north of this area of mixed rock and was probably forcibly intruded into the pyroxenite to cause brecciation and some mixing. The pyroxenite part of the mixed rock consists chiefly of anhedral pyroxene, zoned melanite, sphene, apatite, and sparse amounts of altered melilite. The nepheline syenite is leucocratic

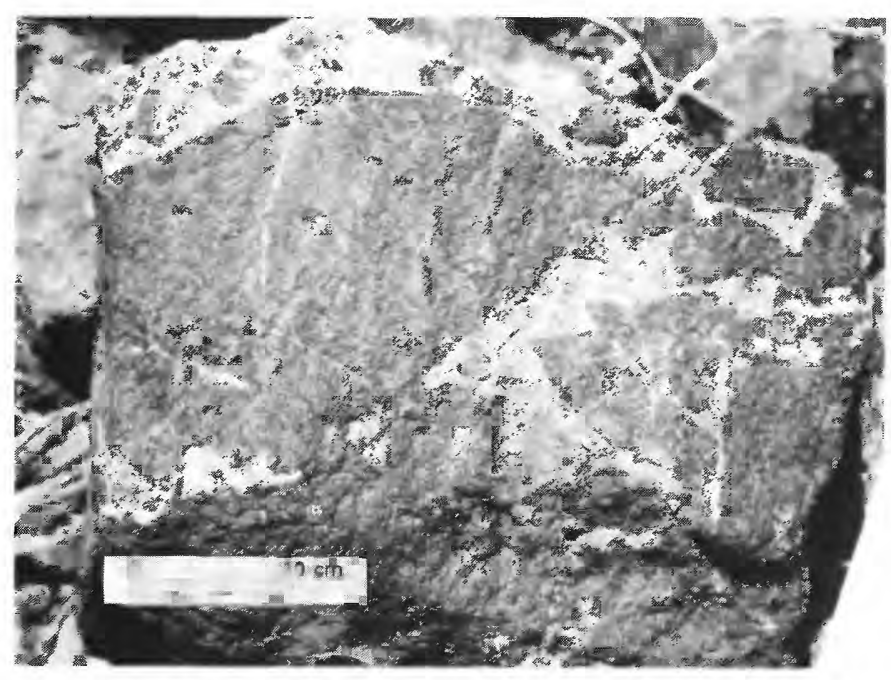

Figure 14.-Mixed pyroxenite-syenite rock from the complex of Iron Hill. The pyroxenite is brecciated, and syenite fills the fractures and locally replaces pyroxenite. and consists chiefly of Carlsbad-twinned orthoclase and minor amounts of melanite, aegirine-augite, and altered nepheline.

\section{CARBONATITE OF IRON HILL}

Dolomitic carbonatite (rauhaugite) is the youngest member in the intrusive series of the alkalic complex of Iron Hill. It occurs as a stock or plug and as numerous dikes both within and outside the complex. The carbonatite stock is roughly elliptical in outcrop, the long axis striking $\mathrm{N} .35^{\circ} \mathrm{W}$., and its $4-\mathrm{km}^{2}$ area is about 12 percent of the outcrop area of the entire complex.

Carbonatite resists weathering more than the surrounding alkalic rocks of the complex, and Iron Hill rises about $300 \mathrm{~m}$ above the floor of the valley of Cebolla Creek or Road Beaver Creek (fig. 15) and above the adjacent pyroxenite. The resistance of the carbonatite to weathering is attributable to the semiarid climate; the jaspery, ferruginous capping or mantle that formed locally on the dolomite by weathering processes; and the cementation of fractures and other zones of weakness in the carbonatite by secondary quartz, carbonates, and iron and manganese oxides.

The carbonatite is generally well exposed except for the more highly timbered east- and north-facing slopes where talus has been stabilized and has accumulated to thicknesses of $6 \mathrm{~m}$ or more. Contacts of the carbonatite stock with the Precambrian country rocks and the alkalic intrusives of the complex are poorly exposed. The best exposures of the contact are near the north end of the stock, along the south side of Huntsman Gulch and along the east side of the valley of Cebolla Creek about midway between Deldorado Creek and Huntsman Gulch. The felsite and granite at these localities are generally sheared, reddened, and fenitized, and the contacts are sharp and discordant. South of Road Beaver Creek the carbonatite-pyroxenite contact is partly concealed by alluvium. Locally along the southern margin of the carbonatite stock there are

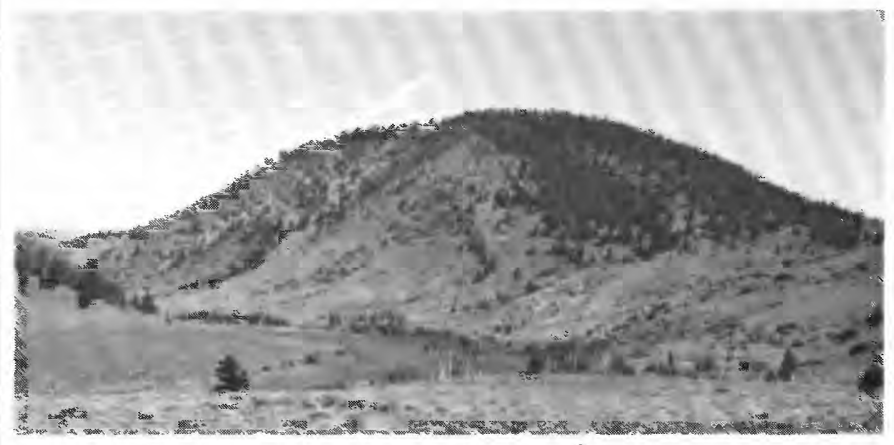

Figure 15.-Iron Hill from the southeast. 
phlogopite-rich zones in the carbonatite that may represent xenoliths of pyroxenite that have been partly replaced by carbonate minerals and phlogopite owing to reaction with the carbonatitic fluid. Near the carbonatite, the pyroxenite is highly veined by carbonates, and the pyroxene is highly altered to biotite, chlorite, or sodic amphiboles in a mixed zone about $100-300 \mathrm{~m}$ thick of thin carbonatite and pyroxenite layers (Temple and Grogan, 1965, p. 681-682).

The west margin of the complex is largely buried by the alluvium of Cebolla Creek, but at one place on the hillside east of Cebolla Creek the contact is with sheared granite and felsite, indicating that the carbonatite stock of Iron Hill was emplaced between pyroxenite on the northeast and southeast and sheared granite and felsite on the southwest. Numerous radial dikes of carbonatite, which cut all the other rock types of the complex, are lithologically similar to the carbonatite stock of Iron Hill and increase in number toward the stock, indicating a genetic relationship.

The carbonatite stock is complex in its internal structures and textural features. These structures and textures include grain sizes ranging from fine to pegmatitic; varying degrees of development of foliation, drag folds, and shear zones; and the presence of partially replaced xenoliths of other rocks near the margins of the body. Most of the internal structures are considered primary, formed during or shortly after

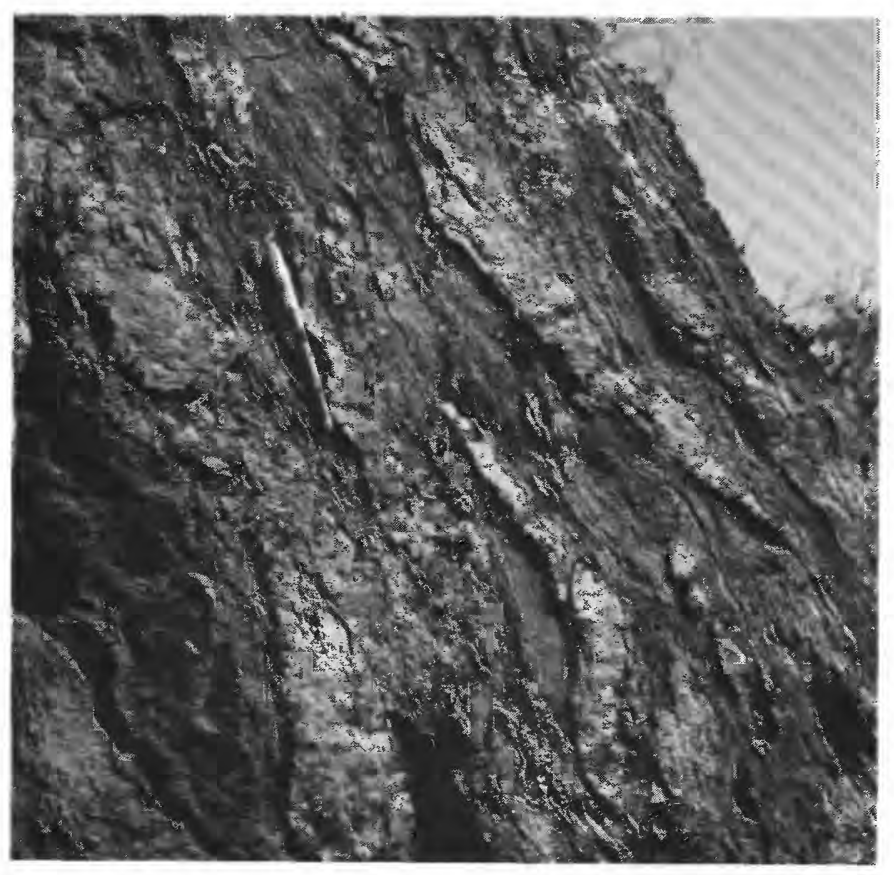

FIGURE 16.-Strongly foliated carbonatite from Iron Hill. Phlogopite and apatite-rich lenticles are locally jasperized and are etched into relief by weathering. intrusion; examples are the foliation surfaces or shear planes along which apatite, phlogopite, or barite have been deposited. Iron or manganese oxides and jasper deposited along joints or other structural features, however, are considered secondary.

The foliation in the carbonatite is well developed, and dips are generally steep to vertical. The foliation is commonly imparted by the presence of apatite-rich seams or segregations, phlogopite-biotite seams, or by strained and deformed carbonate crystals (fig. 16). Between Road Beaver and Deldorado Creeks the foliation surfaces strike dominantly northeast, but a few strike north-northwest along the western margin of the carbonatite. North of Deldorado Creek the strike of the foliation is dominantly northwest but is locally northeast. The pattern of foliation is generally arcuate and convex to the northeast. At the south end of the carbonatite stock the foliation is discordant to the inferred contact of the carbonatite.

Folds within the carbonatite are not common. At one place along Deldorado Creek, a well-exposed 8-cm layer of coarsely crystalline carbonatite is folded into a small drag fold, indicating some deformation after emplacement.

Texturally the carbonatite is heterogeneous; coarsegrained and pegmatitic varieties are in sharp contact with finer grained carbonatite. In some places this sharp change in texture can be attributed to dikes of coarsely crystalline carbonatite cutting finer textured carbonatite. Generally the coarse-grained carbonatite contains less silicate minerals, sulfides, apatite, and pyrochlore than the finer textured varieties.

Mineralogically, the carbonatite stock consists chiefly of ankeritic dolomite and minor amounts of apatite, phlogopite, biotite, barite, pyrite, calcite, magnetite, ilmenite, pyrochlore, and sodic amphiboles. Hematite, manganese oxide, and reddish-brown chalcedonic jasper or quartz occur as secondary minerals. Goethite and hematite pseudomorphs after pyrite and magnetite are common. Pyrolusite forms coatings on joints or vugs in the carbonatite. Apatite, which makes up a few percent to locally 10 percent or more of the carbonatite, is generally a colorless or pale green fluorapatite with $\mathrm{N}_{0}, 1.63-1.64$. The apatite varies from stubby prisms to strongly oriented prismatic aggregates that tend to be localized along foliation surfaces. Much of the apatite appears to be late, as veins of apatite cut the carbonatite or are localized along intergranular or cleavage surfaces of the dolomite crystals. Eight chemical analyses of carbonatite showed a $\mathrm{P}_{2} \mathrm{O}_{5}$ content from 0.13 to 4.34 percent (Hedlund and Olson, 1980 , table 8A). Spectrographic analyses of two apatite concentrates from carbonatite are shown in table 3. 
TABLE 3.-Semiquantitative spectographic, X-ray fluorescent, fluorometric, and radiochemical analyses of pyrochlore and apatite from carbonatite, Iron Hill

[Analysts: J. C. Hamilton, N. M. Conklin, E. J. Fennelly, and A. P. Marranzino. 〉. greater than; $($, less than; leaders $(-)$. analyses did not show any elements in these concentrations]

\begin{tabular}{|c|c|c|c|}
\hline \multirow{2}{*}{$\begin{array}{l}\text { Sample No.----- } \\
\text { Amount } \\
\text { (percent) }\end{array}$} & IH469 & $\mathrm{PH}-\mathrm{C}-1 \mathrm{v}$ & $\mathrm{PH}-\mathrm{c}-\mathrm{V}$ \\
\hline & Pyrochlore & Apatite & Apatite \\
\hline$>10$ & $\mathrm{Nb}(33)^{1}$ & $\mathrm{Ca}, \mathrm{P}$ & $\mathrm{Ca}, \mathrm{P}$ \\
\hline 7 & $\mathrm{Ca}$ & -- & -- \\
\hline 3 & --- & $\mathrm{Mg}$ & $\mathrm{Nb}$ \\
\hline 2 & Çe & -- & --- \\
\hline 1.5 & ${ }^{2} \mathrm{Th}(1.32), \mathrm{Fe}, \mathrm{Ti}$ & -- & $\mathrm{Si}, \mathrm{Mg}$ \\
\hline 1 & $\mathrm{Na}, \mathrm{Ba}, \mathrm{Sr}$ & -- & -- \\
\hline .7 & --- & $\mathrm{Si}, \mathrm{Fe}, \mathrm{Ce}, \mathrm{Nb}$ & $\mathrm{Fe}, \mathrm{Na}, \mathrm{Ce}, \mathrm{Sr}$ \\
\hline .5 & $\mathrm{Fe}, \mathrm{Zr}$ & -- & -- \\
\hline .3 & Si, La, Nd & $\mathrm{Na}, \mathrm{Ti}, \mathrm{Sr}, \mathrm{Nd}$ & Ti, La, Nd \\
\hline .15 & $\mathrm{Pr}, \mathrm{Sm}$ & $\mathrm{Al}, \mathrm{Mn}, \mathrm{La}$ & $\mathrm{Mn}$ \\
\hline .07 & $\mathrm{Mg}, \mathrm{Pb},{ }^{1} \mathrm{Ta}(0.085)$ & --- & -- \\
\hline .05 & $\mathrm{Mn},{ }^{3} \mathrm{U}(0.055)$ & --- & --- \\
\hline .03 & $\mathrm{Eu}$ & $\mathrm{Ba}$ & $\mathrm{Ba}, \mathrm{Y}$ \\
\hline .015 & --- & $\mathrm{Zr}, \mathrm{Eu}, \mathrm{Dy}, \mathrm{Gd}, \mathrm{Y}$ & $\mathrm{Zr}, \mathrm{Eu}, \mathrm{Dy}, \mathrm{Gd}$ \\
\hline .007 & -- & & $\mathrm{Er}$ \\
\hline .005 & $\mathrm{Ag}$ & --- & --- \\
\hline$<.005$ & -- & v & V \\
\hline .003 & -- & $\mathrm{Cu}, \mathrm{Ho}$ & $\mathrm{Pb}, \mathrm{Cu}, \mathrm{Ho}, \mathrm{Sn}$ \\
\hline .0015 & --- & $\mathrm{Cr}, \mathrm{Ni}, \mathrm{Sn}, \mathrm{Yb}$ & $\mathrm{Ni}, \mathrm{Yb}$ \\
\hline .0007 & $\mathrm{Be}$ & & $\mathrm{Cr}, \mathrm{Co}_{0}$ \\
\hline
\end{tabular}

$I_{\text {By } X \text {-ray fluorescent analysis. }}$

2 By radiochemical analysis.

3 By fluorometric analysis.

Pyrite occurs widely in the carbonatite as disseminated cubes as much as $1.2 \mathrm{~cm}$ across, rare pyritohedrons, and as vein fillings. Some of the pyrite grains are poikilitic, containing inclusions of apatite. Other pyrite grains are fractured and veined by secondary quartz.

Barite is disseminated in minor amounts throughout the carbonatite stock and more abundantly in the carbonatite dikes. The barite grains are commonly interstitial to the dolomite, but some barite occurs as veinlets, generally having formed later than the dolomite. In nine analyses of carbonatite the barium content ranges from 0.037 to 4.9 percent; the strontium content ranges from 0.007 to 0.02 percent (Hedlund and Olson, 1980, table 8B).

Phlogopite and sparse amounts of bluish-green hydrobiotite(?) are disseminated sporadically within the carbonatite and also occur as lenticular aggregates. Along the south edge of the carbonatite the phlogopite and associated carbonates locally appear to replace a pyroxenite xenolith. Much of the phlogopite shows strong reverse pleochroism, one or two outer zones showing reversed positions for the pleochroic colors from that of the cores. Generally the cores of the phlogopite plates have a stronger birefringence than the margins. Around individual dolomite inclusions in the phlogopite there is a similar zone of reversed pleochroism. The $\mathrm{N}_{\mathrm{z}}$ value of the cores is 1.613 , whereas that of the marginal resorption zones is $\mathbf{1 . 6 1 4}$ (Larsen, 1942, p. 53). Such reversed pleochroism has been noted in the dark mica of other alkalic rock complexes and was first described at Iron Hill by Larsen (1942, p. 53). The reversed pleochroism of the dark mica was discussed by Nash $(1972$, p. 1365), who found that the significant chemical change between the two types of micas is the decrease of aluminum in the margin with a concomitant increase of iron.

Magnetite is present in small amounts in the carbonatite stock and is partly replaced by hematite to form martite. In one place at the southwest margin of the stock, 2- to 5-cm layers of carbonatite containing abundant magnetite octahedra alternate with biotitic carbonatite in an outcrop area of only a few square meters. The magnetite grains are as much as $1 \mathrm{~cm}$ across and are intergrown with ilmenite.

A computation of the normative carbonate minerals from five analyses (Hedlund and Olson, 1980, table 8A) of carbonatite from the Iron Hill stock indicates that the $\mathrm{CaCO}_{3} / \mathrm{MgCO}_{3}$ ratio is 1.32 whereas the ratio for pure dolomite is 1.185 . This difference is thought to reflect the substitution of $\mathrm{FeCO}_{3}$ and $\mathrm{MnCO}_{3}$ for $\mathrm{MgCO}_{3}$ in the dolomite lattice, which is also indicated by the presence of ferric and manganese oxides along the margins and cleavage surfaces of individual dolomite grains in the weathered carbonatite. About $30 \mathrm{X}$-ray diffraction patterns of carbonatite material from the Iron Hill stock showed predominantly dolomite with very little calcite or other carbonates.

Green, pink, purple, lemon-yellow, and gray pyrochlore is disseminated in minor amounts throughout the dolomitic stock and dikes as tiny octahedral crystals generally less than $3 \mathrm{~mm}$ across (fig. 17). Under the microscope the pyrochlore shows faint anisotropism, and the crystals are weakly zoned. Numerous opaque inclusions related to certain zones are present in some of the grains. The unit cell of the pyrochlore is $10.435 \pm 0.002 \mathrm{~A}$. The pyrochlore is radioactive but not metamict. The radioactivity varies considerably. In one analyzed sample the pyrochlore contains 0.055 percent uranium, 1.32 percent thorium, 33 percent niobium, and only 0.085 percent tantalum (table 3). Microprobe analyses of two pyrochlore samples by Nash $(1972$, p. 1369$)$ indicate 62.5 and 65.4 percent $\mathrm{Nb}_{2} \mathrm{O}_{5}, 2.36$ and 0.31 percent $\mathrm{ThO}_{2}$, and negligible $\mathrm{UO}_{2}$.

The dolomitic carbonatite (rauhaugite) stock of Iron Hill is generally more radioactive than other igneous rocks of the complex but is less radioactive than the carbonatite dikes. Field readings of radioactivity in places exceed $0.1 \mathrm{mr} / \mathrm{hr}$ or five times the background of nearby Powderhorn Granite, and samples mostly range from 3 to $63 \mathrm{ppm}$ thorium. An average of 173 gamma ray spectrometric measurements made by 


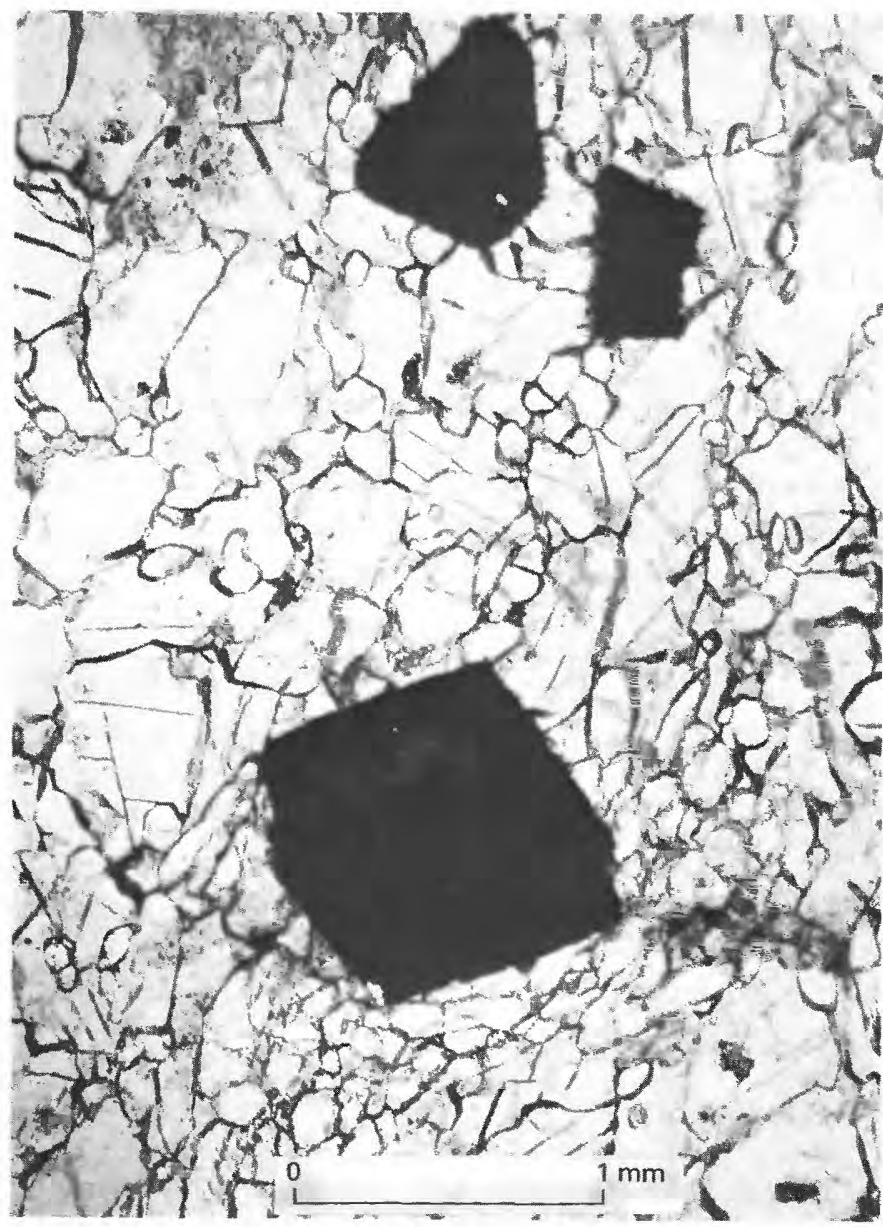

FIGURE 17.-Pyrochlore and apatite in carbonatite, Iron Hill. Euhedral to subhedral pyrochlore (black) in dolomitic carbonatite containing abundant small, rounded grains (high relief) of accessory apatite.

Armbrustmacher (1980; Armbrustmacher and Brownfield, 1979) was $41 \mathrm{ppm} \mathrm{ThO}_{2}$. The radioactivity of the carbonatite stock is probably due chiefly to thoriumbearing pyrochlore (table 3), although other thoriumbearing minerals may also be present.

\section{CARBONATITE DIKES}

Several hundred carbonatite dikes were mapped in pyroxenite and other rocks in and just outside of the complex. They are distributed radially about the carbonatite stock of Iron Hill although there is a great preponderance of $\mathrm{N} .45^{\circ}-85^{\circ} \mathrm{W}$. strikes parallel to the long dimension of the complex. Dikes and plugs of carbonatite cut all other alkalic rocks of the complex and also less commonly cut the surrounding Precambrian rocks. The dike orientations show a similarity to the directions of strong jointing in the adjacent alkalic rocks. This similarity suggests that fractures that developed in the complex prior to or during the intru- sion of the Iron Hill carbonatite stock influenced the orientation of the dikes.

The carbonatite dikes commonly have sharp contacts with the wall rocks. Many are about 1 to $1.5 \mathrm{~m}$ thick, but some are as much as $\mathbf{4 5} \mathrm{m}$ thick. Most are fairly homogeneous, but layered and brecciated dikes are also present. The layering parallels the walls of some dikes and is commonly due to the alternation of sideritic layers with calcitic or dolomitic layers or to the alternation of silicated carbonatite layers with nonsilicated carbonatite. The siderite-rich layers commonly weather dark gray or black, which sharply contrasts with the light brown color of the weathered dolomite. The silicated carbonatite commonly contains abundant phlogopite and biotite, and some of the micas are altered to a bluish-green hydrobiotite(?). The brecciated texture of some carbonatite dikes is probably related to the forcible injection of carbonatitic fluids. Some fragments consist of partially replaced pyroxenite inclusions characterized by carbonate pseudomorphs after pyroxene and thin selvages of phlogopite about the margins of the former pyroxene crystal.

Carbonatite dikes also cut the Precambrian rocks outside the complex of Iron Hill. At one locality, about $0.5 \mathrm{~km} \mathrm{~N} .46^{\circ} \mathrm{W}$. from the Powderhorn Post Office, there are inclusions of felsite within a carbonatite dike. Foliation or flow structure within the carbonatite wraps about the largest inclusion (figs. 18 and 19), which suggests flowage about the inclusion after the carbonatite was largely crystallized.

Most carbonatite dikes in Precambrian wall rocks are within $1.2 \mathrm{~km}$ of the margin of the pyroxenite of the

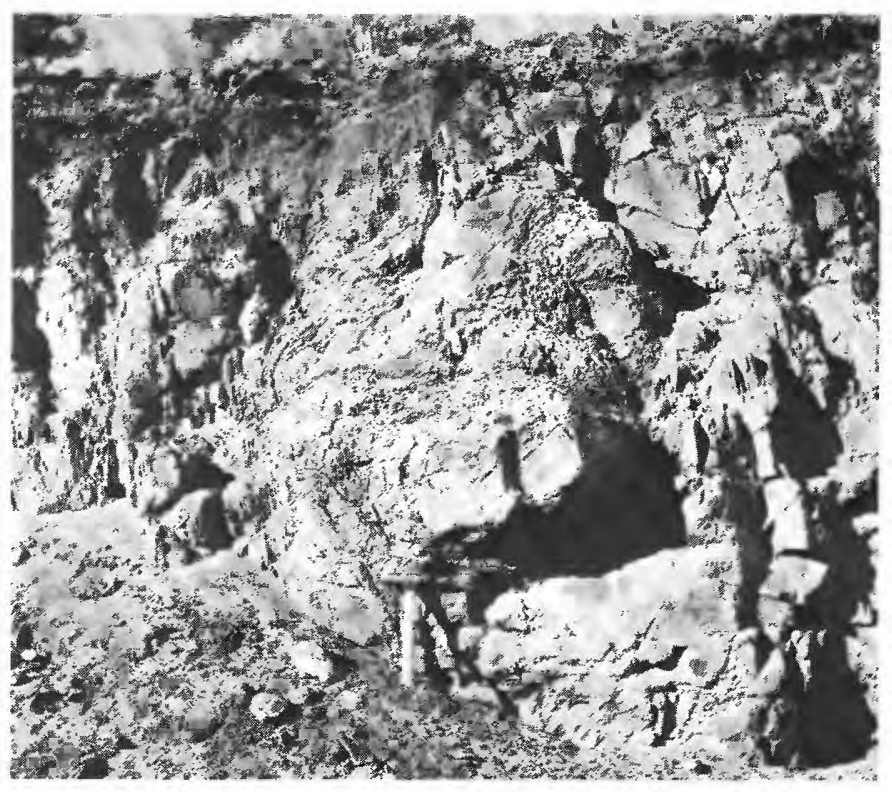

FIGURE 18.-Inclusion of felsite in carbonatite dike. Position of inclusion and foliation in carbonatite are shown in figure 19. 


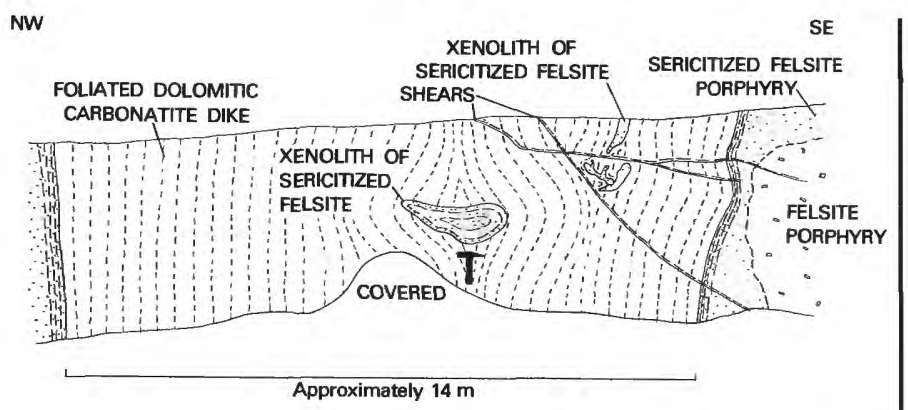

FIGURE 19.-Sketch of felsite xenoliths in carbonatite dike (fig. 18), $0.5 \mathrm{~km}$ west-northwest of Powderhorn Post Office. Foliae within the carbonatite wrap about the xenoliths.

complex of Iron Hill. In the Gateview quadrangle, only two small carbonatite dikes were found, 0.3 and $1.2 \mathrm{~m}$ thick. Of these the most distant carbonatite dike from the complex of Iron Hill was noted on the east side of Goose Creek near the old Dubois mine. It is calcitic and coarse grained, contains accessory orthoclase and pyrite, and is slightly radioactive. A semiquantitative spectrographic analysis of the carbonatite (Hedlund and Olson, 1980, table 3, G2630) shows a suite of elements similar to dikes in or near the complex.

In decreasing order of abundance, the minerals in the carbonatite dikes are dolomite, calcite, siderite, biotite, phlogopite, pyrite, barite, apatite, orthoclase, pyrochlore, monazite, chalcopyrite, sphalerite, galena, fluorite, synchysite, and parisite. The siderite occurs in a few dikes as distinct layers or segregations. The micas are disseminated and also form lenticular aggregates. The sulfide grains, especially pyrite, tend to be in clusters and are most abundant in the sideritic carbonatite dikes. Pyrite is the most common sulfide and is in cubes that show varying degrees of oxidation to goethite or hematite. The sphalerite contains exsolution blebs of chalcopyrite, and a few chalcopyrite grains occur outside the sphalerite host. Galena is present in very minor amounts associated with the sphalerite.

Eight partial chemical and 14 spectrographic analyses of carbonatite samples from various occurrences, tabulated by Hedlund and Olson (1980, table $8 \mathrm{~A}-8 \mathrm{~B}$ ), show $\mathrm{a} \mathrm{CaCO}_{3} / \mathrm{MgCO}_{3}$ ratio ranging from 1.79 to 5.18. These include samples from eight localities in the carbonatite stock of Iron Hill, three from carbonatite dikes, and one from a small pluglike body. The three carbonatite dike samples are atypical variants of carbonatite containing calcite, siderite, and $\mathrm{FeCO}_{3}$-rich dolomite. They differ considerably in composition from the other samples, having higher $\mathrm{FeCO}_{3}$ content and lower $\mathrm{MgO}_{3}$ content, and this difference probably indicates fractionation of the carbonatitic fluids.

The carbonatite dikes are the most radioactive rocks in the alkalic complex of Iron Hill. Of 214 dikes in the
Powderhorn quadrangle, for example, 132 have radioactivities ranging from 0.05 to $0.79 \mathrm{mr} / \mathrm{hr}$ or two to 35 times the background of typical Powderhorn Granite. Thirty samples of the dikes contain about 30 to 3,200 ppm thorium. The more radioactive dikes commonly have a crudely layered structure, weather chocolate brown, and contain dolomite, siderite, calcite, barite, pyrite, apatite, hydrobiotite(?), and small amounts of monazite, pyrochlore, bastnaesite, and synchysite. The weakly radioactive carbonatite dikes are relatively homogeneous, weather buff or rusty yellow, and contain dolomite, calcite, apatite, pyrite, hydrobiotite(?), and sparse barite.

No mineral in which thorium is a major constituent is known in the carbonatite dikes. Some thorium is present in the sparse monazite, which contains about 0.15 percent thorium, and in pyrochlore. Monazite is more common in the carbonatite dikes than in the carbonatite stock. The monazite is very fine grained, reddish brown, resinous, and where identified is mostly associated with barite. Rare earths in the carbonatites range from a trace to about 1.5 percent and occur in monazite, in the fluocarbonates synchysite and bastnaesite, and also substitute for calcium in apatite and pyrochlore.

A few localities for uncommon minerals identified by $\mathrm{X}$-ray are: bastnaesite and synchysite in a carbonatite dike just east of Iron Hill in SE1/4, sec. 12, T. 46 N., R. $2 \mathrm{~W}$.; monazite in a carbonatite dike from $\mathrm{N} 1 / 2$, sec. 11 , T. 46 N., R. 11/2 W., and rutile from one in $\mathrm{SE}^{1 / 4}$, sec. 12 , T. 46 N., R. $1 \frac{1}{2}$ W.; galena in a carbonatite dike in $\mathrm{N} 1 / 2$, sec. 11 , T. 46 N., R. $1 \frac{1 / 2}{}$ W., and sphalerite in a carbonatite dike in $\mathrm{SE}^{1 / 4}$, sec. 12 , T. 46 N., R. 2 W.

\section{IGNEOUS ROCKS AND VEINS OUTSIDE THE COMPLEX OF IRON HILL}

\section{TRACHYTE PORPHYRY DIKES}

Pink or red, porphyritic to aphanitic trachyte dikes occur chiefly in the Powderhorn and Rudolph Hill quadrangles. They cut most Precambrian rocks but do not cut any alkalic rocks, diabase, or rocks younger than the Precambrian. The trachyte dikes are commonly 1.5 to $3 \mathrm{~m}$ thick but may be as much as $25 \mathrm{~m}$ thick. The dikes show some branching and sharp changes in strike, follow the local joint pattern, and are clearly structurally controlled. Many have low dips toward the complex of Iron Hill.

The trachyte is composed of scattered, alined, stubby to lath-shaped red orthoclase phenocrysts commonly 3 to $5 \mathrm{~mm}$ long set in a trachytic, aphanitic groundmass consisting of alined orthoclase microlites. The orthoclase contains abundant dusty ferric oxide inclusions. Some of the trachyte dikes are autobrec- 
ciated, as angular fragments of coarsely textured trachyte occur in a fine-grained trachytic groundmass. The fragments generally consist of anhedral aggregates of coarse-grained orthoclase. Granite fragments have been observed as rare inclusions in some of the trachyte. Mafic minerals are rare in the trachyte and are chiefly interstitial iron oxides.

Some of the trachyte dikes are radioactive, generally about four times that $(0.02 \mathrm{mr} / \mathrm{hr})$ of nearby felsic metavolcanics; readimgs of 0.04 to $0.08 \mathrm{mr} / \mathrm{hr}$ are common. Most trachyte dikes are relatively low grade; hence, their contribution to $\mathrm{ThO}_{2}$ resources (table 5) is small. The trachyte dikes resemble some of the thorite veins in that they contain abundant red orthoclase, but the igneous origin of the dikes is indicated by the porphyritic texture. Locally the wall rocks are replaced by orthoclase in a thin zone resembling fenite along the margins of some of the trachyte dikes. Freshly broken trachyte dike rock commonly has a fetid odor resembling garlic that also characterizes the thorium veins and some fenite.

\section{FINE-GRAINED GRANITE}

Fine-grained granite of uncertain age occurs within 2 $\mathrm{km}$ south and west of the complex of Iron Hill and is anomalously radioactive. The granite occurs in numerous dikelike bodies, irregular small plutons about 150-750 m wide, and two larger bodies 3-4 $\mathrm{km}$ by $600-1,200 \mathrm{~m}$. The granite is mostly fine grained, some is medium grained, and locally it is porphyritic. It is composed of microcline microperthite, quartz, plagioclase, and biotite. Associated with the granite near Road Beaver Creek are two bodies of melasyenite 60-120 m wide.

The fine-grained granite was considered by Hunter (1925) to be a variety of the Powderhorn Granite of Precambrian age. On the geologic maps of the Rudolph Hill (Olson, 1974) and Powderhorn (Hedlund and Olson, 1975) quadrangles, however, it is shown as a separate Precambrian(?) unit. It appears relatively little deformed in comparison with adjoining gneissic coarse-grained Powderhorn Granite. The granite is fenitized in places, as shown by feldspathization and blue-green amphibole veinlets, and it is cut by carbonatite, lamprophyre, and thorium veins that are probably related to the complex of Iron Hill. Some of the fine-grained granite occurs in crudely arcuate plutons around the southern part of the complex of Iron Hill. These forms, which are suggestive of ring dikes, together with the locally high radioactivity, may indicate a genetic link between fine-grained granite bodies and the complex.
The fine-grained body west of Cebolla Creek near the north edge of the Rudolph Hill quadrangle (Olson, 1974) is at least $4 \mathrm{~km}$ long but is covered by Tertiary welded tuff at the south end. This granite is cut by many thorium-bearing veins but is not in itself highly radioactive where studied. Another granite pluton that crosses Cebolla Creek $5 \mathrm{~km}$ south of Powderhorn is about $3.3 \mathrm{~km}$ long and $1.2 \mathrm{~km}$ wide. It is strongly fenitized near the complex of Iron Hill. The radioactivity has been measured in only a few places. In the roadcut at the south end of the valley of Cebolla Creek, measurements with a gamma-ray spectrometer in slightly fenitized granite suggest a possible range of 40 to nearly $300 \mathrm{ppm} \mathrm{ThO}_{2}$. This thorium-bearing part of the granite, which may average on the order of 100 ppm $\mathrm{ThO}_{2}$, appears at least $120 \mathrm{~m}$ wide, but it has not been delineated and may be only a minor part of the entire granite body.

The fine-grained granite bodies on the canyon sides of Road Beaver Creek, 0.5 to $2 \mathrm{~km}$ south of the margin of the complex of Iron Hill, have been explored by numerous bulldozer trenches. These granites are in secs. 24 and 25, T. 46 N., R. 11/2 W., and are shown on the map of the Rudolph Hill quadrangle (Olson, 1974). In this area five granite bodies are 300 to $1,000 \mathrm{~m}$ in exposed length and 100 to $500 \mathrm{~m}$ wide. Within the plutons the radioactivity of the fine-grained granite varies considerably. Samples from some of the more radioactive, small, local concentrations exceed 1,000 ppm in thorium. Considerable parts of the granites, however, have thorium contents on the order of 100 to $225 \mathrm{ppm}$, as judged by eight samples and hundreds of field gamma-ray spectrometer readimgs. The eight samples of the granite analyzed in the laboratory range from 32 to $281 \mathrm{ppm}$ thorium and average $115.1 \mathrm{ppm}$ (131 ppm $\mathrm{ThO}_{2}$ ). Areas that have the most radioactivity are typically characterized by red and yellow-brown limonitic staining and by narrow, black, siliceous, rusty-weathering veinlets along joint or shear planes, suggesting transport and deposition of thorium by iron-bearing solutions.

A spectrographic analysis of a sample of the granite containing abundant limonite veinlets showed, in weight percent, 0.7 phosphorus, manganese, barium, cerium, and lanthanum; 0.3 neodymium and strontium; 0.07 titanium and praseodymium; 0.03 gadolimum, samarium, and yttrium; 0.015 niobium, lead, and vanadium; and 0.007 dysprosium and zirconium. Thorium was determined radiochemically to be 0.08 percent in this sample. The rare earths are unusually abundant, particularly the light or cerium group of rare earths; the niobium content is also anomalous relative to other granites in the area but is not as high as in some of the alkalic rocks. 


\section{THORITE VEINS}

About 250 thorium veins are shown on geologic quadrangle maps of the Powderhorn district and are illustrated on figure 20 . Of these about 200 are in the Gateview (Olson and Hedlund, 1973) and Powderhorn (Hedlund and Olson, 1975) quadrangles and the remainder in the Rudolph Hill (Olson, 1974) and Carpenter Ridge (Hedlund and Olson, 1973) quadrangles.

The thorite veins contain the highest grade thorium concentrations in the district. The $\mathrm{ThO}_{2}$ content of the thorite veins ranges from less than 0.01 percent to as much as 4.9 percent in high-grade samples. The $\mathrm{ThO}_{2}$ content is generally less than 1 percent, however, and is only 0.05 to 0.1 percent in many of the veins examined in the district. The veins are as much as $1 \mathrm{~km}$ in length, but most cannot be traced for more than $100 \mathrm{~m}$. They range in thickness from $1 \mathrm{~cm}$ or less to $5 \mathrm{~m}$ but most are less than $0.6 \mathrm{~m}$ thick. They commonly occur in steeply dipping shear or breccia zones within the Precambrian rocks. In one of the principal areas, near the north end of Huntsman Mesa, 3 to $8 \mathrm{~km}$ north of the complex of Iron Hill, most of the veins strike slightly north of east. In the Sapinero MesaGoose Creek area, in the northwestern part of the district, however, the veins generally strike northwest. The veins are generally discordant to the foliation of hornblende schist, felsite, quartz-biotite schist, granite, syenite, and other rocks, the type of host rock apparently having little effect on the localization of the veins.

The thorium veins are composed of thorite, white to smoky quartz, jasper, pink potassic feldspar, calcite, specular and earthy hematite, goethite, magnetite, barite, and pyrite, and sporadic galena, chalcopyrite, sphalerite, synchysite, apatite, fluorite, biotite, sodic amphibole, rutile, monazite, vanadinite, and bastnaesite.

Pink to red, poorly twinned orthoclase is common in the veins as large laths or as clustered subhedral to anhedral grains. Minor amounts of microcline are present in some veins. Adjacent to most veins the wall rocks have been partly replaced by pink to red orthoclase, and this fenitelike replacement is conspicuous where hornblende schist wall rocks are reddened and altered to biotitic and chloritic rocks alongside the veins. Some breccia fragments of feldspathized wall rocks have been incorporated in the veins. Thin feldspathic fracture fillings 1 to $3 \mathrm{~cm}$ thick in Precambrian melasyenite or other rocks are locally radioactive, giving readings of as much as $0.06 \mathrm{mr} / \mathrm{hr}$ or three times background.

The chief thorium mineral is thorite, much of which is partly metamict but shows an X-ray pattern for thorite (or thorogummite). The thorite is very fine grained and is intergrown with ferric oxides. A thorium-bearing phosphate with rhabdophanelike structure has been found locally in the district (Dooley and Hathaway, 1961, p. 340). Monazite has been found in several veins.

Pink to white barite is present in small amounts in many of the thorium veins and is a major constituent in a few of them. At one locality on the ridge west of Goose Creek a discontinuous vein of massive, light pink barite $60 \mathrm{~cm}$ thick cuts the hornblende schist. Barite occurs in at least two generations in relation to orthoclase. Some early formed barite is intergrown with quartz. Other grains occur as inclusions in orthoclase and are partly replaced by orthoclase. Most barite appears later than the potassium feldspar, however, and veinlets of barite in orthoclase are common, especially along cleavage surfaces in the feldspar. The pink to red color of some barite may to be due to minute inclusions of ferric oxide observed in thin section.

Orthoclase and quartz formed early as primary minerals in the veins. Quartz occurs in at least two generations. The early quartz, some of which is smoky, occurs as anhedral and euhedral grains intergrown with orthoclase or barite. The later generation of quartz is commonly chalcedonic quartz that occurs as pseudomorphs after orthoclase or other silicates and as vug fillings. Much of this secondary quartz is associated with ferric oxides.

Carbonate minerals, chiefly calcite or ankeritic dolomite, are present in many of the thorite veins. They commonly appear to replace silicates, quartz, and barite, and are typically associated with ferric oxides. In some veins the carbonate minerals are present as pseudomorphs after prismatic silicate minerals. Coarsely crystalline calcite fills vugs in some veins. Some rare carbonate veinlets have been observed to cut the jasper and are believed to have formed at the time of Oligocene volcanism, unlike the bulk of the carbonate, which is of probable Cambrian or late Precambrian age.

Apatite and fluorite are present as rare constituents in a few veins. Apatite was noted as minute inclusions in orthoclase.

Specular hematite is not abundant but is conspicuous in some veins. It forms veinlets that cut early formed orthoclase, barite, and quartz. Earthy hematite and goethite are weathering products of iron-bearing minerals such as pyrite and specular hematite. In some small areas, numerous dispersed, thin, red hematitic or limonitic feldspathized veinlets and seams occur, locally causing a radioactivity of two to three times background. Red staining due to hematite accompanies some thorium mineralization and has encouraged some exploration of red rocks, but hematitic veinlets are also abundant in some places that are low in radioactivity. 


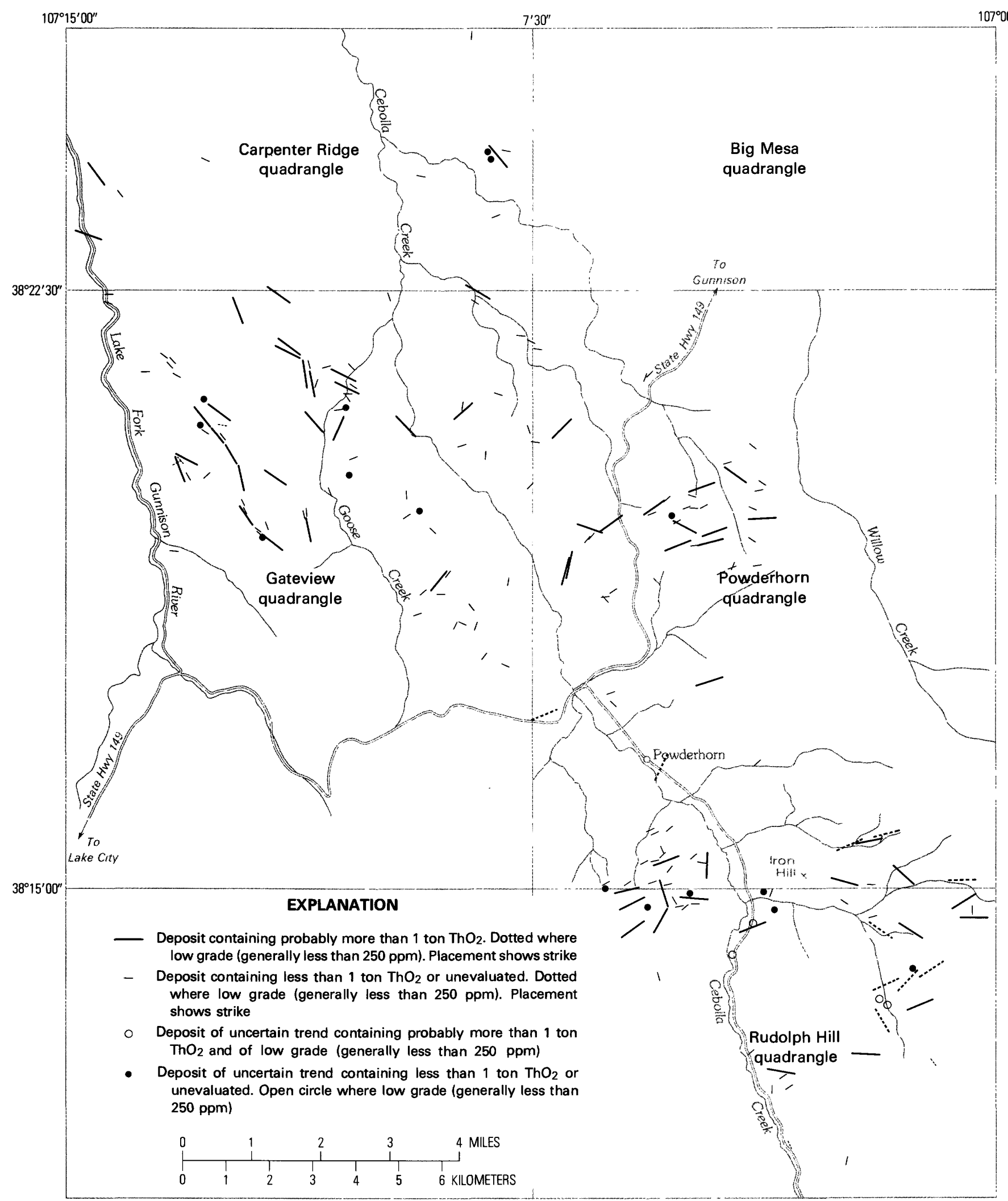

FIGURE 20.-Map showing distribution and trend of thorium deposits, Powderhorn district.

The thorite is so fine grained and sparsely distributed that its place in the paragenetic sequence is difficult to establish. Because thorite is commonly associated with earthy hematite and goethite, it may 
be about the same age as the specular hematite and formed fairly late in the paragenetic sequence.

Biotite and sodic amphiboles are sparsely distributed in many thorite veins. Some of the biotite represents detached parts of biotitic wall rocks or formed by replacement of hornblendic wall-rock fragments. The sodic amphiboles, which have nearly parallel extinction and high birefringence, occur as radiating clusters or as aggregates of prisms in the veins.

Pyrite, chalcopyrite, galena, and minor sphalerite are present but not generally abundant in the thorite veins. The sulfide minerals are generally later and occur as veinlets filling fractures in orthoclase and barite and occupying interstices between barite grains. The chalcopyrite forms exsolution blebs in sphalerite and also occurs as separate grains. Galena is intergrown with sphalerite.

Varicolored jasper, mostly yellowish to reddish brown, has generally replaced the carbonate gangue of the veins on Sapinero Mesa and similar areas where the veins were near the surface that was covered by volcanic rocks in Oligocene time. The jasper is found to at least $30 \mathrm{~m}$ below the mesa level, and oxidation extends locally to at least 60-m depth. Within the deep canyons of the Lake Fork of the Gunnison River and Cebolla Creek, however, jasperization and oxidation have been less intense, and unaltered sulfide minerals persist in a few of the veins.

The veins have been altered and leached during several cycles. An earlier one is related to the surface on which the Junction Creek Sandstone of Jurassic age was deposited and may have resulted in some shallow jasperization of carbonate mineral in the vein. Later periods of oxidation and leaching are related to the Oligocene surface, on which the volcanic rocks were deposited, and also to the present cycle of weathering. Most of the silicification is probably a hydrothermal replacement localized near the ancient Oligocene surface just beneath the base of the flows.

The effects of oxidation, leaching, and jasperization of the veins on the original thorium content are not clearly known because few workings have penetrated more than $10 \mathrm{~m}$ in depth. Jasperized veins on the mesa surfaces show radioactivity in both jasper and carbonate gangue. Locally the jasper forms pseudomorphic replacements of the carbonate and has apparently retained some dispersed thorium. Oxidation, leaching, and jasperization might result in some enricliment or diminution in grade of near-surface vein material, but without sufficient subsurface data on possible changes in grade, the surface exposures are assumed to be reasonably representative of the grade of vein material at depth.
The following minerals probably occur in numerous other veins, but a few localities are listed. Bastnaesite and synchysite, for instance, have been identified by $\mathrm{X}$-ray analysis from a vein in $\mathrm{SE}^{1 / 4} / 4$ sec. $2, \mathrm{~T} .47 \mathrm{~N}$., R. 3 W. Bastnaesite occurs in a vein near Razor Creek in $\mathrm{NW}^{1 / 4} \mathrm{sec} .27$, T. 47 N., R. $3 \mathrm{E}$. and synchysite in a vein in $\mathrm{NE}^{1 / 4}$ sec. 20 , T. 47 N., R. 2 W. Monazite and vanadinite were identified in a vein in NW1/4 sec. $2, T .47 \mathrm{~N}$., R. 3 W., and rutile in veins in $\mathrm{SE}^{1 / 4} / 4$ sec. 2, T. 47 N., R. 3 W., and NW $1 / 4$ sec. 8, T. 47 N., R. 2 W. Galena and cerussite were found in a vein in NE1/4 sec. $20, T .47 \mathrm{~N}$., R. 2 W., and galena in veins in $\mathrm{NW}^{1 / 4}$ and $\mathrm{SE}^{1 / 4} \mathrm{sec}$. 2 , T. 47 N., R. 3 W.

\section{DIABASE AND GABBRO DIKES}

Several northwest-trending gabbro and diabase dikes occur in a narrow zone that cuts across the alkalic-rock complex. Similar dikes also occur in Precambrian rock elsewhere in the district. The gabbro and diabase dikes have the lowest radioactivity of the major rock types in the immediate area. They are as much as $150 \mathrm{~m}$ thick and $6.7 \mathrm{~km}$ in length. They are predominantly tholeiitic, but within the complex, one nepheline-bearing gabbro also occurs (Larsen, 1942, p. 28-29).

Most of the dikes have a diabasic texture and are referred to as diabase in this discussion. The diabase dikes are black, commonly weather rusty brown, locally show spheroidal weathering, and are medium grained with an intergranular hypidiomorphic to subophitic texture. Augite grains partly mantle the labradorite $\left(\mathrm{An}_{52-55}\right)$ laths and partly occupy interstices between labradorite grains. The labradorite laths show oscillatory-normal zoning. The augite commonly is very pale purple and has only faint pleochroism; $\mathrm{Z}$ c, $47^{\circ} ; \mathrm{Nz}, 1.715 ; \mathrm{Nx}, 1.690 ; 2 \mathrm{~V}=65^{\circ} \pm 5^{\circ}$. Augite constitutes about 25 percent by volume of the diabase; some augite grains show incipient alteration to chlorite and biotite. Magnetite and ilmenite(?) occur as aggregated granules and skeletal crystals that may be as much as 25 percent of the diabase.

Three diabase dikes crop out in the complex of Iron Hill and are clearly younger than the rocks of the complex. These dikes resemble in mineralogy, texture, and attitude the other, genetically related, west-northweststriking diabase dikes of the region, but they are generally thicker, coarser grained, and locally have a strong trachytic texture. The dikes cut pyroxenite, nepheline syenite, and fenite of the complex but were not observed to cut the carbonatite stock. Carbonatite dikes and veins do not cut the diabase.

The diabase is generally coarse grained, ophitic, and locally trachytic in the thicker parts of the dikes. 
Where the dikes are thinner the texture changes to fine to medium grained and a hypidiomorphic-granular texture is common. Marginal chill zones, present along some of the diabase dikes, are porphyritic with phenocrysts of labradorite and augite. The groundmass makes up about 80 percent of the rock and consists of plagioclase microlites, minute grains of augite, and magnetite. Some of the augite phenocrysts have mantles of a later generation of pyroxene.

\section{FAULTS}

The Powderhorn district is on the south side of the Gunnison uplift, a northwest-trending block roughly 30 by $100 \mathrm{~km}$ in size, composed of Precambrian rocks overlain by Mesozoic sediments, which was elevated in Laramide time. Within the district, Precambrian metamorphic foliation and elongate metamorphic and igneous bodies trend mostly northeast to east. This older trend is cut by many younger Precambrian faults, shear zones, and Cambrian or Ordovician diabase dikes that strike predominantly northwest (Olson and others, 1977). Many of the thorium veins are in northwest-trending faults and shear zones, although trends vary in different parts of the district.

The Gunnison uplift is bounded on the south by the northwest-trending Cimarron fault, which passes near Powderhorn (fig. 4). The concealed Cimarron fault is indicated by a series of six springs and travertine spring deposits that strike approximately $\mathrm{N}$. $70 \mathrm{~W}$. along the southwest side of Cebolla Creek at Powderhorn. Six travertine spring deposits can be mapped, although they coalesce in places. Movement on the Cimarron fault took place in Laramide time, although earlier movement may have occurred in late Precambrian time (Olson and others, 1977). Northwest of Powderhorn, the position of the fault at the beginning of Oligocene volcanism was marked by a long, southward-facing scarp, against which the early, intermediate-composition flows and volcanic breccias accumulated. Diabase dikes of Cambrian or Ordovician age parallel the Cimarron fault zone and are thus related to it in trend, but considerable postdike fault movement has occurred as some dikes are cut by the fault.

The Cimarron fault cuts the complex of Iron Hill and can be traced northwestward along strike at least $65 \mathrm{~km}$. Southeast of the complex the fault is buried by Oligocene volcanic rocks. For most of its length, the fault shows a displacement, northeast side upthrown, of $1,000 \mathrm{~m}$ or more. Much of this movement occurred after the Mancos Shale of Cretaceous age was deposited. A fault block of Junction Creek Sandstone of Jurassic age crops out along the east side of
Powderhorn Creek about $500 \mathrm{~m}$ south of the old Powderhorn Post Office. This sandstone block is slightly tilted and the base is at an elevation of about $2,470 \mathrm{~m}$. This elevation represents a difference of about $520 \mathrm{~m}$ from the elevation of the Junction Creek Sandstone outcrop on Huntsman Mesa to the northeast and $400 \mathrm{~m}$ difference from the outcrop of sandstone on Tolvar Peak. The different levels are accounted for by fault displacement, but the fault or faults are concealed.

Where the fault cuts the eastern part of the complex of Iron Hill, the displacement, as shown by offset of the Junction Creek Sandstone of Jurassic age, is very small and is probably no more than $50-120 \mathrm{~m}$, with the south side upthrown. Post-Jurassic movement was greater, however, on a different but probably related east-trending fault that crosses the south end of Huntsman Mesa and cuts granite just north of the complex, because the Junction Creek Sandstone is displaced about 250 to $300 \mathrm{~m}$ in this area, south side upthrown. These displacements of south side up relative to north differ from the relative displacements of north side upthrown, shown along the Cimarron fault from Powderhorn northwestward. They are, however, compatible with the sense of displacement interpreted to have occurred between the two sides of the fault within the complex of Iron Hill. The varying amounts of displacement at different points along the Cimarron fault are taken up in part by northeast- to east-trending cross faults that divide the major blocks into smaller ones of varying throw.

Erosion since the fault movement has exposed two different levels in the alkalic stock. Whereas pyroxenite and ijolite are found on both sides of the fault, the block southwest of the fault contains the Iron Hill carbonatite body, a greater number of thin carbonatite dikes, and abundant uncompaligrite; it also has a generally wider fenite zone. The block northeast of the fault contains an abundance of nepheline syenite and magnetite-ilmenite-perovskite dikes, far more than found in the southwest block. The carbonatite and uncompaligrite southwest of the fault may well represent the deeper seated rocks, as interpreted by Temple and Grogan $(1965$, p. 689), in which case the fault movement at this point was the reverse of that farther northwest.

To account for the great difference between rocks of the complex of Iron Hill on the two sides of the fault, more displacement would seem to be required than is shown by the offset of Mesozoic sediments. Some preJurassic movement is therefore inferred. The Cimarron fault was apparently active over a long period of time and may also have been active in late Precambrian time and even have been a factor in the localization 
of the complex of Iron Hill (Olson and others, 1977, p. 686).

\section{RESOURCES $^{1}$ OF THORIUM AND ASSOCIATED ELEMENTS}

\section{THORIUM}

Thorium exploration has been aimed at finding thorium concentrations of several tenths of a percent $\mathrm{ThO}_{2}$ or more, such as are found in the thorite veins, in a few of the carbonatite dikes, and in some trachyte. Lower grade material, containing 0.02 to 0.1 percent $\mathrm{ThO}_{2}$, adds significantly to total thorium resources in the district (Olson and Overstreet, 1964, p. 23) and includes, in addition to the thorite veins, concentrations in carbonatite, magnetite-ilmenite-perovskite bodies, trachyte porphyry dikes, and small plutons of granite.

Thorium deposits shown on maps in the Powderhorn district number at least 261, which are concentrated in the Gateview and Powderhorn quadrangles. The majority of the deposits are small or low in grade; hence, it is only a minority that contribute significantly to total resources. Sixty-seven localities, including most of the richer deposits, were examined with the aid of a portable four-channel gamma-ray spectrometer, and 66 samples were collected. An additional 35 samples were collected from outside the Powderhorn district to provide additional data for calibration purposes. The samples were analyzed by C. M. Bunker and C. A. Bush for thorium, RaeU, and potassium by laboratory gamma-ray spectrometry. The field gamma-ray spectrometer readings were calibrated with the sample analyses from the same stations by a linear regression analysis to provide a rough guide to approximate thorium content for field readings on unsampled veins.

The gamma-ray spectrometer readings, coupled with sample analytical data, provide a reasonable approximation of the thorium content of the surficial part of the deposit. Projecting these readings to infer reserves at depth requires consideration of the amount of cover that might locally obscure the vein; the dispersal of radioactive elements by slope wash, soil creep, or leaching; the possible enrichinent of surficial material by selective removal of constituents other than thorium; as well as the known variability of thorium mineralization from place to place, particularly in the thorite veins. Generally, the surficial thorium content was assumed to be fairly representative of that at depth except where radioactivity may be obscured by ground cover.

\footnotetext{
${ }^{1}$ The mining industry presently uses the inch-pound system of measurements.
}

For indicated ore, a depth was assumed of from onethird to one times the surface length of the vein, to a maximum of 1,000 feet; for inferred ore a maximum depth of $1 \frac{1 / 2}{2}$ to two times the surface length was used, to a maximum of 3,000 feet.

Resource estimates of thorium veins in the Powderhorn district, compiled as cumulative totals, according to average grade of deposit, are shown in table 4, and the minimum amount of $\mathrm{ThO}_{2}$ estimated to be present at various grades is shown graphically on figure 21 . As the curve is for minimum amounts, the actual amount of $\mathrm{ThO}_{2}$ present is somewhere to the right of the curve shown, perhaps two or three times as much.

In order to relate the reserves to the cost of producing the thorium, a method of cost analysis was designed by the U.S. Bureau of Mines for mine and mill costs to recover thorium from thorite vein deposits (Lemons and Coppa, 1979). The cost analyses were made on the veins that contain more than 35,000 short tons of indicated and inferred reserves. In testing the Powderhorn veins by cost analysis, it was found that $\mathrm{ThO}_{2}$ might be obtained for less than $\$ 30$ per lb (pound) in those having a grade of at least 0.15 percent $\mathrm{ThO}_{2}$ $(1,500 \mathrm{ppm})$. Very few, if any, veins averaging less than $700 \mathrm{ppm} \mathrm{ThO}_{2}$ could be expected to produce $\mathrm{ThO}_{2}$ at a

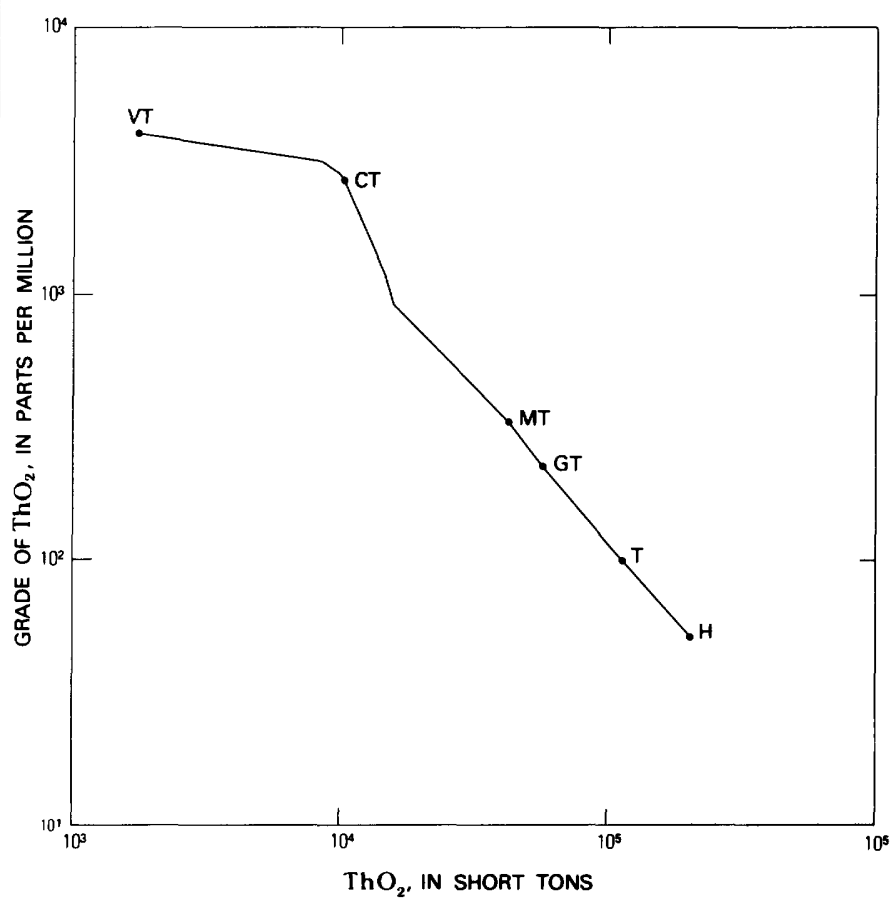

FIGURE 21.-Curve showing cumulative total of $\mathrm{ThO}_{2}$ resources at various grades. Thorite veins (tonnages at several grades of $\mathrm{ThO}_{2}$ are plotted along VT; minimum of $100 \mathrm{ppm}$ plotted at T). Carbonatite dikes (several grades along CT); magnetiteperovskite rock (MT); thorium-rich granite (GT); carbonatite stock of Iron Hill (H). 
TABLE 4.- $\mathrm{ThO}_{2}$ resources in the Powderhorn district

[Values in short tons. Figures for carbonatite dikes are for only 10 dikes that have been estimated. The total, including other carbonatite dikes, is probably at least several times these amounts. Undiscovered resources in all categories are not included, but they would probably at least double the resource estimates for veins, carbonatite dikes, and granite. The total number of veins estimated is 56 , and the number of carbonatite dikes is actually 10 . These numbers are less than the total shown because several deposits are repeated by dividing them into more than one grade category. ), greater than]

\begin{tabular}{|c|c|c|c|c|c|c|c|c|c|}
\hline & \multirow{2}{*}{$\begin{array}{l}\text { Grade } \\
\text { range } \\
(\mathrm{ppm}) \\
\end{array}$} & \multicolumn{4}{|c|}{ Reserves } & \multicolumn{4}{|c|}{ Cumulative totals } \\
\hline & & $\begin{array}{c}\text { No. of } \\
\text { deposits }\end{array}$ & Indicated & Inferred & Total & $\begin{array}{l}\text { No. of } \\
\text { deposits }\end{array}$ & Indicated & Inferred & Total \\
\hline $\begin{array}{l}\text { Veins.............. } \\
\text { Carbonatite dikes... } \\
\text { Veins.............. }\end{array}$ & $\begin{array}{r}>1,000 \\
>1,000 \\
500-1,000\end{array}$ & $\begin{array}{r}13 \\
2 \\
15\end{array}$ & $\begin{array}{r}1,800 \\
100 \\
200\end{array}$ & $\begin{array}{r}7,900 \\
200 \\
600\end{array}$ & $\begin{array}{r}9,700 \\
300 \\
800\end{array}$ & $\begin{array}{l}13 \\
15 \\
30\end{array}$ & $\begin{array}{l}1,800 \\
1,900 \\
2,100\end{array}$ & $\begin{array}{l}7,900 \\
8,100 \\
8,700\end{array}$ & $\begin{array}{r}9,700 \\
10,000 \\
10,800\end{array}$ \\
\hline $\begin{array}{l}\text { Carbonatite dikes.. } \\
\text { Veins............... } \\
\text { Carbonatite dikes.. } \\
\text { Magnetite-perovskite }\end{array}$ & $\begin{array}{r}500-1,000 \\
100-500 \\
100-500\end{array}$ & $\begin{array}{r}1 \\
38 \\
9\end{array}$ & $\begin{array}{r}500 \\
1,400 \\
700\end{array}$ & $\begin{array}{l}1,000 \\
3,800 \\
1,000\end{array}$ & $\begin{array}{l}1,500 \\
5,200 \\
1,700\end{array}$ & $\begin{array}{l}31 \\
69 \\
78\end{array}$ & $\begin{array}{l}2,600 \\
4,000 \\
4,700\end{array}$ & $\begin{array}{r}9,700 \\
13,500 \\
14,500\end{array}$ & $\begin{array}{l}12,300 \\
17,500 \\
19,200\end{array}$ \\
\hline 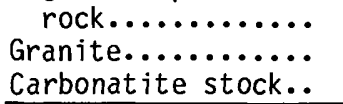 & $\begin{array}{r} \pm 250 \\
>100 \\
41\end{array}$ & $\begin{array}{r}1 ? \\
5 \\
1\end{array}$ & $\begin{array}{r}\text { None } \\
5,000 \\
30,000\end{array}$ & $\begin{array}{r}25,000 \\
9,000 \\
110,000\end{array}$ & $\begin{array}{r}25,000 \\
14,000 \\
140,000\end{array}$ & $\begin{array}{l}79 \\
84 \\
85\end{array}$ & $\begin{array}{r}4,700 \\
9,700 \\
39,700\end{array}$ & $\begin{array}{r}39,500 \\
48,500 \\
158,500\end{array}$ & $\begin{array}{r}44,200 \\
58,200 \\
198,200\end{array}$ \\
\hline
\end{tabular}

cost of less than $\$ 50$ per lb. The approximate cost categories of the reserves (in veins only) are shown in table 5.

Indicated and inferred reserves in veins exceeding $500 \mathrm{ppm} \mathrm{ThO}_{2}$ in average grade amount to 10,400 short tons, as shown in the two columns on the left side of the table. Of this total, 95 percent is estimated to be in only seven deposits. The other four categories on the right side of the table are made up of veins having more than 700 ppm $\mathrm{ThO}_{2}$.

The larger and higher grade veins, which contain a large proportion of the resources estimated in veins exceeding 500 ppm $\mathrm{ThO}_{2}$ (table 4), are found in secs. 14, 15, 16, and 20, T. 47 N., R. 2 W.; secs. 1, 2, 4, 9, 10, 15, and 24 , T. 47 N., R. 3 W.; sec. 34 , T. 48 N., R. 3 W.; sec. 10, T. 47 N., R. 2 W.; and secs. 23 and 24 , T. 46 N., R. $11 / 2 \mathrm{~W}$. These areas are shown on figure 22 along with the areas of thorium-bearing magnetiteperovskite rock, carbonatite, and thorium-bearing granite.

Five deposits account for the 9,300 tons of reserves estimated, from the U.S. Bureau of Mines cost analysis, to be producible at less than $\$ 30$ per lb. The \$30-50 per lb category is made up of ore in seven deposits.

Analysis of production costs likely for low-grade disseminated deposits minable by open-cut methods suggests that some of the lower grade thorium resources in the fine-grained granite plutons near Powderhorn may be minable by open-cut methods at a cost on the order of $\$ 50-100$ per $\mathrm{lb}^{\mathrm{ThO}} \mathrm{Th}_{2}$ (Staatz and others, 1979). Parts of the granites of four small areas in the Road Beaver Creek drainage and one near Cebolla Creek, judging from gamma-ray spectrometer measurements and eight sample analyses, range mostly from 100 to $200 \mathrm{ppm} \mathrm{ThO}_{2}$ in average grade, probably averaging a little more than $100 \mathrm{ppm} \mathrm{ThO}_{2}$. Parts of the granite contain $200 \mathrm{ppm}$ or more, and the highest sample analysis of $1,600 \mathrm{ppm} \mathrm{ThO}_{2}$ was from part of the granite that contains abundant limonitic material as small veins. The granites of the five areas are estimated to have a combined tonnage of about 125 million tons of rock. At an assumed overall average grade of 112 ppm $\mathrm{ThO}_{2}$, this amount of granite is inferred to contain at least 14,000 tons $\mathrm{ThO}_{2}$ (at least 5,000 tons indicated and 9,000 tons inferred), and additional low-grade resources probably exist in other parts of the granite bodies not estimated.

Thorium oxide content of the carbonatite stock of Iron Hill has been estimated by Armbrustmacher (1980) to average $41 \mathrm{ppm}$; thus, to a depth of $245 \mathrm{~m}$ the 3.4 billion tons of carbonatite would contain about 140,000 tons $\mathrm{ThO}_{2}$. Other elements in the same amount of rock were estimated (Armbrustmacher, 1980) as $1,900,000$ tons $\mathrm{Nb}_{2} \mathrm{O}_{5}$ (570 ppm); $13,500,000$ tons combined rare-earth oxides $(3,970 \mathrm{ppm})$, and 43,000 tons $\mathrm{U}_{3} \mathrm{O}_{8}(12.7 \mathrm{ppm})$. Inasmuch as the content of thorium and the other elements is not uniform, some large parts

TABLE 5.-Indicated and inferred reserves of $\mathrm{ThO}_{2}$ in veins of more than 500 ppm $\mathrm{ThO}_{2}$ average grade in the Powderhorn district

[Values are in short tons]

\begin{tabular}{|c|c|c|c|}
\hline Total & Total & $\begin{array}{l}\text { Producible at less } \\
\text { than } \$ 30 / 1 \mathrm{~b}\end{array}$ & $\begin{array}{c}\text { Producible at between } \\
\$ 30 \text { and } \$ 50 / 1 \mathrm{~b}\end{array}$ \\
\hline indicated & inferred & Indicated Inferred & Indicated Inferred \\
\hline 1,900 & 8,500 & 1,600 & 200 \\
\hline
\end{tabular}




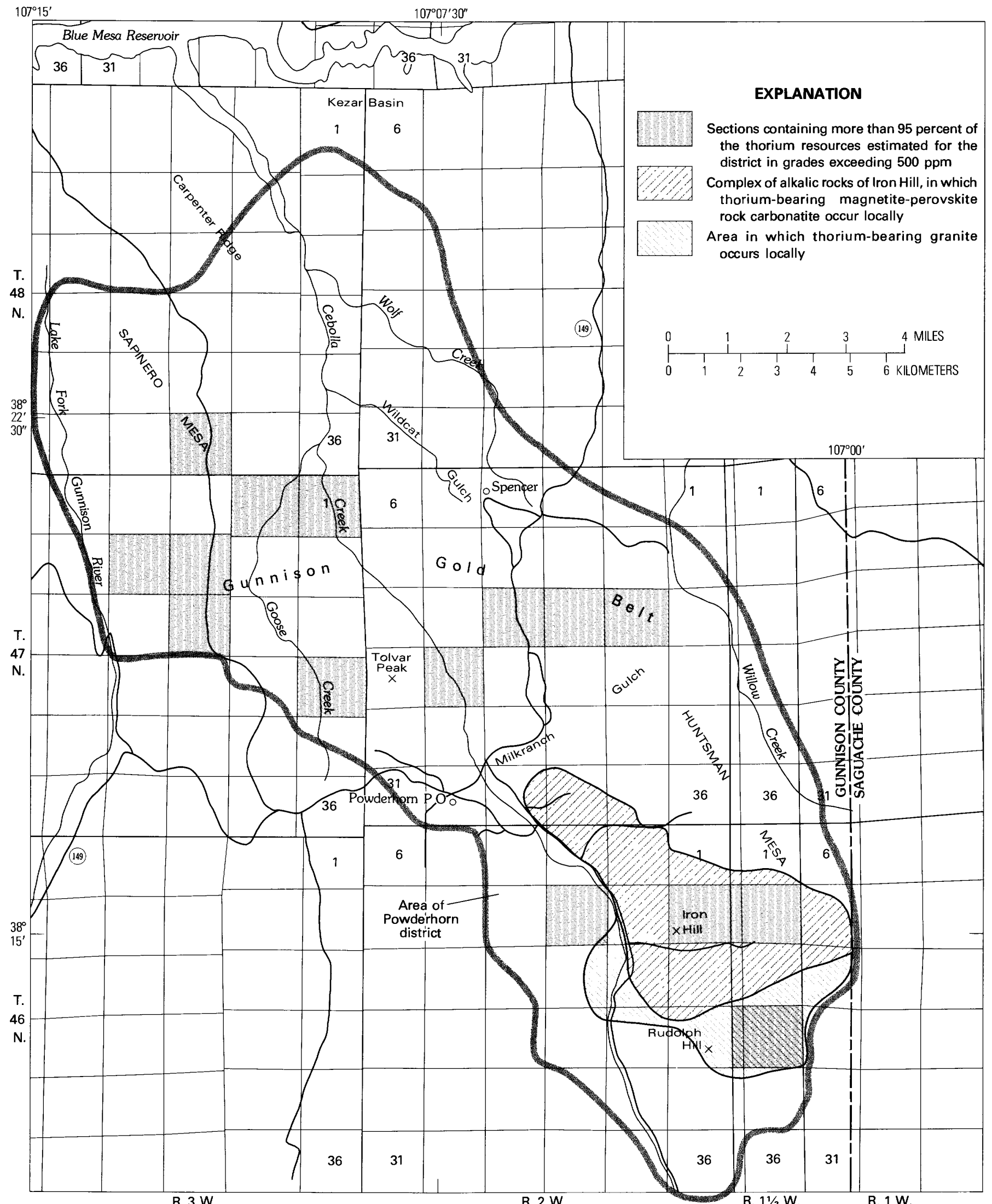

R. 3 W.

R. 2 W.

R. $1 \frac{1}{2} \mathrm{~W}$.

R. 1 W.

FIGURE 22.-Map showing areas of principal thorium resources estimated in veins, magnetite-perovskite rock, carbonatite, and thoriumbearing gramite. 
of the carbonatite are higher or lower than the average grade. For example, Temple and Grogan (1965, p. 673) estimated a reserve of more than 100,000 tons of $\mathrm{Nb}_{2} \mathrm{O}_{5}$ in rock averaging at least 0.25 percent $\mathrm{Nb}_{2} \mathrm{O}_{5}$; some parts of this tonnage, large enough for open-pit mining, were 0.35 percent $\mathrm{Nb}_{2} \mathrm{O}_{5}$. Similarly, higher $\mathrm{ThO}_{2}$ concentrations of 60 to 100 ppm probably occur locally in parts of the carbonatite body large enough to be quarried.

The $\mathrm{ThO}_{2}$ content of the magnetite-ilmeniteperovskite rock has been approximated from only a few available analyses, which are summarized in table 6.

These data suggest a $\mathrm{ThO}_{2}$ content in the magnetiteilmenite-perovskite rock of perhaps 200-500 ppm; the radiochemical analyses, compared with $\mathrm{TiO}_{2}$ in the same samples, suggest an approximate $\mathrm{TiO}_{2} / \mathrm{ThO}_{2}$ ratio of about 380 . The grade of $\mathrm{TiO}_{2}$ in this rock is discussed in the section on "Titanium." From these approximate figures, 100 million tons of such rock, if mined and processed for titanium at 12 percent $\mathrm{TiO}_{2}$ grade, might be expected to contain on the order of 25,000-50,000 tons $\mathrm{ThO}_{2}$; the actual tonnage available may be several times this amount.

\section{ASSOCIATED ELEMENTS}

The economic potential of thorium in the Powderhorn district is related in part to other elements and potential mineral commodities that have been prospected in the area. The complex of Iron Hill contains a minor-element assemblage characteristic of many alkalic rocks, including iron, titanium, phosphorus, strontium, barium, niobium, thorium, rare earths, and vanadium. Potential economic products include niobium, titanium, iron, and rare-earth elements.

TABLE 6.- $\mathrm{ThO}_{2}$ content of magnetite-ilmenite-perouskite rock, complex of Iron Hill

[), greater than; leaders (-), not analyzed for]

\begin{tabular}{|c|c|c|c|c|}
\hline \multirow[b]{2}{*}{ Material } & \multicolumn{4}{|c|}{ Content in percent } \\
\hline & $\mathrm{ThO}_{2}$ or $\mathrm{eThO}_{2}$ & $\mathrm{TiO}_{2}$ & $\mathrm{Nb}$ & Rare earths \\
\hline $\begin{array}{l}\text { Magnetite-ilmenite-perovskite } \\
\text { rock } N J X-1, \text { spectrographic } \\
\text { analysis........................ }\end{array}$ & 0.025 & $>10$ & 0.07 & 0.772 \\
\hline $\begin{array}{l}\text { Two radiochemical analyses } \\
\text { of perovskite.................... }\end{array}$ & $.12-.15$ & 51 & .34 & --- \\
\hline 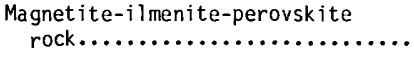 & .01 & --- & -- & .003 \\
\hline $\begin{array}{l}\text { Magnetite-ilmenite-perovskite rock } \\
\text { Temple and Grogan, } 1965 \text {, p. 688) }\end{array}$ & .05 & --- & $\cdots$ & --- \\
\hline $\begin{array}{l}\text { Magnetite-i } 1 \text { menite-perovskite } \\
\text { rock }(0.05-0.25 \mathrm{mr} / \mathrm{hr} \text { field } \\
\text { readings, approximate }) . . . . . . . . .\end{array}$ & ...0076-.0680 & -- & --- & --- \\
\hline
\end{tabular}

TABLE 7.- $\mathrm{ThO}_{2}$ and $/ \mathrm{Nb}_{2} \mathrm{O}_{5}$ ratios in veins in the Powderhorn district

\begin{tabular}{|c|c|}
\hline $\begin{array}{c}\text { No. of } \\
\text { analyses }\end{array}$ & $\mathrm{ThO}_{2}: \mathrm{Nb}_{2} \mathrm{O}_{5}$ \\
\hline 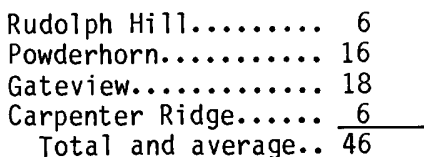 & $\begin{array}{r}2.55 \\
5.50 \\
15.81 \\
19.70 \\
6.79\end{array}$ \\
\hline
\end{tabular}

\section{NIOBIUM}

Niobium occurs in pyrochlore disseminated throughout much of the dolomitic carbonatite stock. Drilling by the DuPont Co. in 1957 and 1958 indicated a reserve of more than 100,000 tons of $\mathrm{Nb}_{2} \mathrm{O}_{5}$ in carbonatite averaging at least 0.25 percent $\mathrm{Nb}_{2} \mathrm{O}_{5}$, a substantial amount of which averaged 0.35 percent. This reserve estimate was subsequently increased by underground work and additional drilling (Temple and Grogan, 1965, p. 673).

The pyrochlore is most abundant in the finer textured dolomitic carbonatite and also associated with fluorapatite along shear planes in the carbonatite. Small amounts of niobium also occur in several other minerals in the complex of Iron Hill. Semiquantitative spectrographic analyses of three perovskite concentrates from the magnetite-ilmenite-perovskite rock show niobium values of $0.17,0.2$, and 0.7 percent. Niobium is also present in trace anounts in the ilmenite, sphene, magnetite, and melanite.

The thorite veins commonly contain anomalous ainounts of niobium; some of it is in columbite, which has been identified in a black siliceous vein in the Road Beaver Creek area (Temple and Grogan, 1965, p. 684). Rough calculations from semiquantitative spectrographic analyses of 46 thorite vein samples show niobium in amounts generally from 30 to $1,500 \mathrm{ppm}$, averaging $172 \mathrm{ppm}\left(246 \mathrm{ppm} \mathrm{Nb}_{2} \mathrm{O}_{5}\right)$. This amount may be compared to an average of $1,669 \mathrm{ppm}$ for $\mathrm{ThO}_{2}$ in the same saunples, a $\mathrm{ThO}_{2}-\mathrm{Nb}_{2} \mathrm{O}_{5}$ ratio of 6.79 . The $\mathrm{ThO}_{2}-\mathrm{Nb}_{2} \mathrm{O}_{5}$ ratio varies in veins in different parts of the districts, however, as shown in table 7. The $\mathrm{ThO}_{2}^{-}$ $\mathrm{Nb}_{2} \mathrm{O}_{5}$ ratio in the thorite veins thus increases, from southeast to northwest, with increasing distance from the complex of Iron Hill. Within the carbonatite body of the complex of Iron $\mathrm{Hill}$, the $\mathrm{Nb}_{2} \mathrm{O}_{5}$ content greatly exceeds $\mathrm{ThO}_{2}$.

\section{TITANIUM}

Titanium-bearing minerals are abundant in the pyroxenite of the complex of Iron Hill. These include perovskite, ilmenite, leucoxene, sphene, melanite garnet, and titaniferous magnetite; minor amounts are present in diopside (0.1-0.7 percent) and biotite. The 
magnetite, ilmenite, and perovskite are commonly intergrown in a titanium-rich rock that forms segregations and dikes, and they also are disseminated as discrete grains in the pyroxenite. The perovskite is partly replaced by leucoxene, but the other titaniumbearing minerals show this alteration less commonly. Sphene and melanite are commonly intergrown with the silicates of the pyroxenite and occur less commonly as granular aggregates. The $\mathrm{TiO}_{2}$ content of perovskite concentrates is about 51 percent, of the magnetiteilmenite composite grains about 6 to 19 percent, and of melanite concentrates about 5 percent. Some titanium is in solid solution in the magnetite, and the $\mathrm{TiO}_{2}$ content of two samples of magnetite is 3.90 and $\mathbf{1 5 . 0}$ percent.

Modal analyses of 102 thin sections of pyroxenite indicate an average weight percentage of the following minerals in the pyroxenite: magnetite-ilmenite, 18.4; perovskite, 2.4; leucoxene, 1.1; melanite, 3.3; sphene, 0.5 percent.

According to Larsen $\left(1942\right.$, p. 57), the $\mathrm{TiO}_{2}$ content averages 7.4 percent in the pyroxenite and is more than 35 percent in some of the magnetite-ilmeniteperovskite bodies. Partial chemical analyses of pyroxenite drill-core samples have been published by Rose and Shannon (1960). Their data from 441 analyses, derived from three drill cores totaling $569.5 \mathrm{~m}$ of mostly pyroxenite, indicate that within the pyroxenite the $\mathrm{TiO}_{2}$ content ranges from 0.3 to 11.9 percent and the total iron content from 7.0 to 22.5 percent. Rose and Shannon $(1960$, p. 19) estimated from surface- and coresample data that the average grade of the pyroxenite is 11.7 percent iron and 6.5 percent titanium, and that the deposit may contain more than 100 million tons. The same figures are given by Berkenkotter and Hazen (1963), who made statistical studies of the drill-core sample data supplied by Rose and Shannon. As the titanium content is highest in the magnetite-ilmeniteperovskite dikes and segregations, the parts of the pyroxenite containing large amounts of such rocks exceed the average titanium content and offer the most promise for titanium exploration.

The pyroxenite has been explored for titanium during the mid 1970's by Buttes Gas and Oil Co. A newspaper account (Denver Post, February 25, 1976, p. 31) reported company officials as saying that studies had indicated 419 million tons of reserves of rock averaging about 12 percent $\mathrm{TiO}_{2}$.

\section{IRON}

Iron deposits were discovered in the Powderhorn district before 1880 . The iron content of the material mined has not been sufficient to attract mining for iron alone, and the total production has been less than 4,000 tons (Harrer and Tesch, 1959, p. 33). The iron occurs chiefly as magnetite-ilmenite-perovskite concentrations in pyroxenite. Thirteen samples of the titaniferous magnetite rock range from 8.6 to 30.8 percent iron and 3.8 to 32.7 percent $\mathrm{TiO}_{2}$ (Harrer and Tesch, 1959, p. 34). An average of 11.7 percent iron for more than 100 million tons of magnetite-bearing pyroxenite was given by Rose and Shannon (1960, p. 19). Small iron deposits in the carbonatite of Iron Hill have also been prospected; these consist of small martiteapatite veins and small bodies of cellular and siliceous limonite and hematite.

\section{VANADIUM}

Vanadium is present in the iron- and titaniumbearing minerals of the complex. Magnetite in one sample of uncompahgrite contains 0.21 percent $\mathrm{V}_{2} \mathrm{O}_{5}$, and a magnetite sample from a magnetite-ilmeniteperovskite dike contains 0.14 percent $\mathrm{V}_{2} \mathrm{O}_{5}$. Other mineral samples with the greatest concentration are melanite garnet, which contains 0.2 percent $\mathrm{V}_{2} \mathrm{O}_{5}$; perovskite 0.06 percent $\mathrm{V}_{2} \mathrm{O}_{5}$; and diopside, 0.05-0.07 percent $\mathrm{V}_{2} \mathrm{O}_{5}$.

Vanadium is commonly reported in spectrographic analyses of thorite veins. Vanadinite was identified in a sample from the Sand Rock No. 5 Lode $1 \mathrm{~km}$ northwest of the old Dubois mine by M. H. Staatz. In 45 semiquantitative spectrographic analyses (Hedlund and Olson, 1980) of vein samples, vanadium ranges from 0 to 1.5 percent, averaging 0.069 percent. This is a higher concentration than is found in most of the alkalic igneous rocks in the district. Probably the highest concentration is in the titaniferous magnetiteilmenite-perovskite rocks, containing on the order of 0.1 percent $\mathrm{V}_{2} \mathrm{O}_{5}$. Fischer $(1975$, p. 5) has estimated that about 50,000 tons of vanadium may occur in 100 million tons of magnetite-ilmenite-perovskite rock in the complex of Iron Hill.

\section{RARE-EARTH ELEMENTS}

All the various types of thorium deposits in the district contain an appreciable amount of rare-earth elements, generally considerably in excess of the thorium. In the thorite veins the ratio of total rare-earth oxides to $\mathrm{ThO}_{2}$ averages about 2.4. The rare earths occur at least partly in such minerals as monazite, thorite, rhabdophane, synchysite, and bastnaesite. Rough calculations based on semiquantitative spectrographic analyses, mostly of veins but including other rock types as well, indicate that in the entire district the ratio of light (cerium-group) rare-earth oxides to tho- 


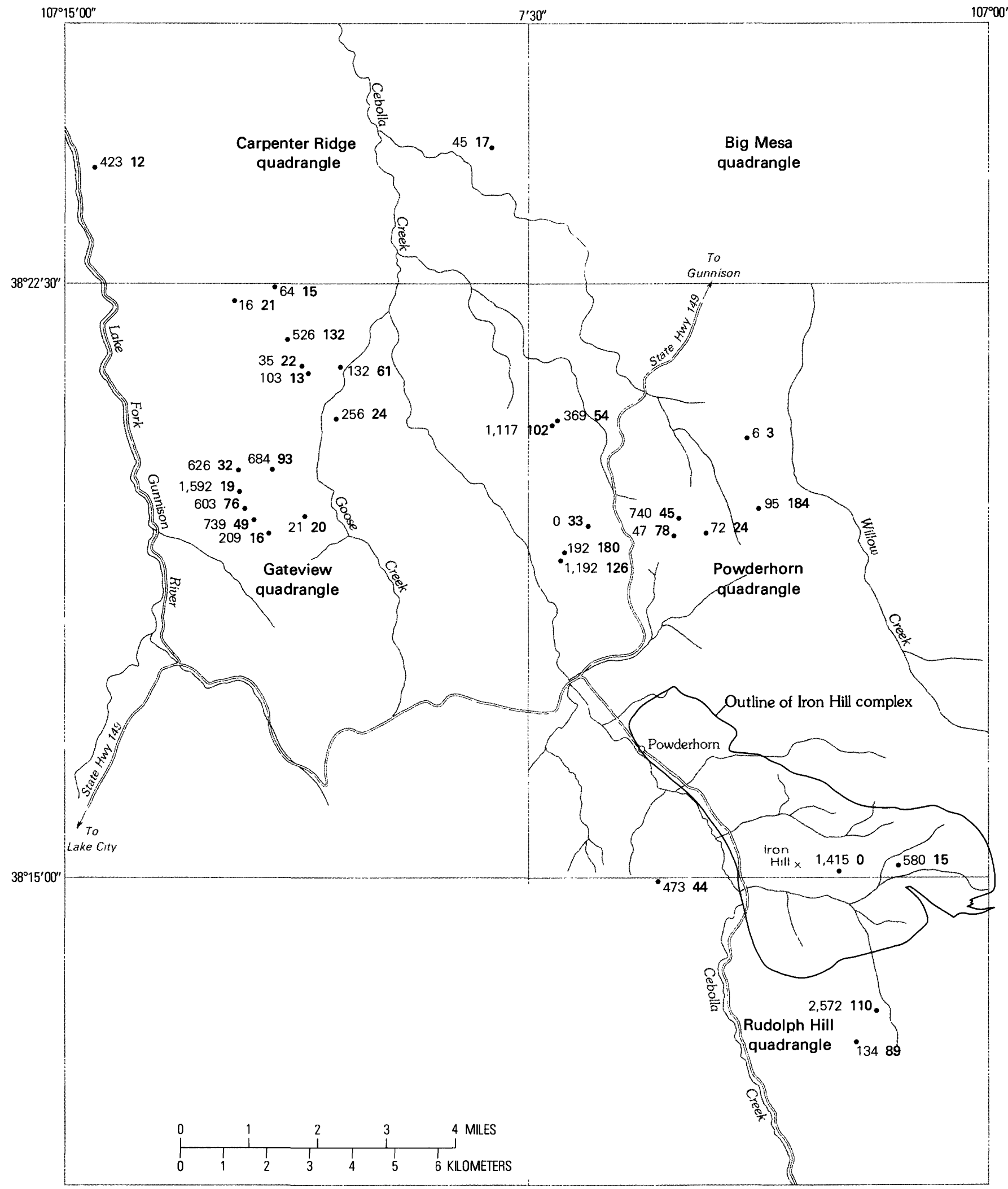

FIGURE 23.-Map showing proportions of cerium-group rare-earth oxides, yttrium-group rare-earth oxides, and thorium oxide in samples from 31 thorium deposits. Numbers show ratios of cerium-group rare-earth oxides (light type) and yttrium-group rare-earth oxides (bold type) to thorium oxide taken as 100 . Amounts are approximate only, as they are based upon semiquantitative spectrographic analyses. 
TABLE 8.-Ratio of cerium-group rare-earth oxides to $\mathrm{ThO}_{2}$ to yttrium-group rare-earth oxides in various thorium deposits

\begin{tabular}{|c|c|c|}
\hline & $\begin{array}{l}\mathrm{Ce} \\
\mathrm{ea} \\
\mathrm{yt}\end{array}$ & $\begin{array}{l}\text { Cerium-group rare- } \\
\text { earth oxides: } \mathrm{Th}_{2} \text { : } \\
\text { yttrium-group rare } \\
\text { earth oxides }\end{array}$ \\
\hline 1. & 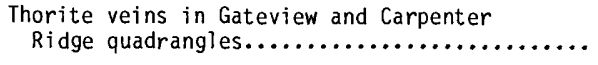 & $1.8: 1: 0.4$ \\
\hline 2. & $\begin{array}{l}\text { Thorite veins in Powderhorn quadrangle exclud- } \\
\text { ing vicinity of complex of Iron Hill......... }\end{array}$ & $0.6: 1: 0.78$ \\
\hline 3. & 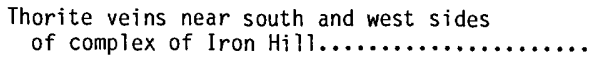 & $4.6: 1: 0.45$ \\
\hline 4. & 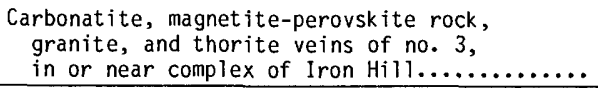 & $6.0: 1: 0.31$ \\
\hline
\end{tabular}

rium oxide to heavy (yttrium-group) rare-earth oxides is about 3.6 to 1 to 0.5 . Restricting the ratios to thorite veins containing more than $100 \mathrm{ppm} \mathrm{ThO}_{2}$ only, these ratios are about 1.75 to 1 to 0.65 . Like the niobiumthorium oxide ratios, the proportions of these three groups of constituents vary considerably in different parts of the district (fig. 23). These variations are summarized in table 8. Individual deposits differ greatly in rare-earth-thorium ratios from nearby deposits, sug- gesting that fractionation of rare-earth metals and thorium-and probably niobium as well-has taken place on a local as well as a district-wide scale. The variation in proportions of rare-earth metals, thorium, and niobium may be due partly to fractionation associated with changes in the composition of the fluids with distance from the source. In part the variations correlate very roughly with carbonate mineral content, for the deposits richer in carbonate minerals, as near the complex of Iron Hill, generally have a higher proportion of cerium in relation to the other elements.

The relation of cerium- and yttrium-group metals to $\mathrm{ThO}_{2}$ content in 59 samples of thorium deposits is illustrated in figures 24 and 25.

\section{URANIUM}

The ratio of thorium to uranium was determined for 74 samples of thorite veins. Uranium content is generally quite low and exceeds $10 \mathrm{ppm}$ in only three of the samples, in which it consists of $11.78,20$, and $41 \mathrm{ppm}$. Of the 74 samples, the thorium-uranium ratio ranged from 1 to 10 in six, 10 to 30 in eight, 30 to 70 in 20,70

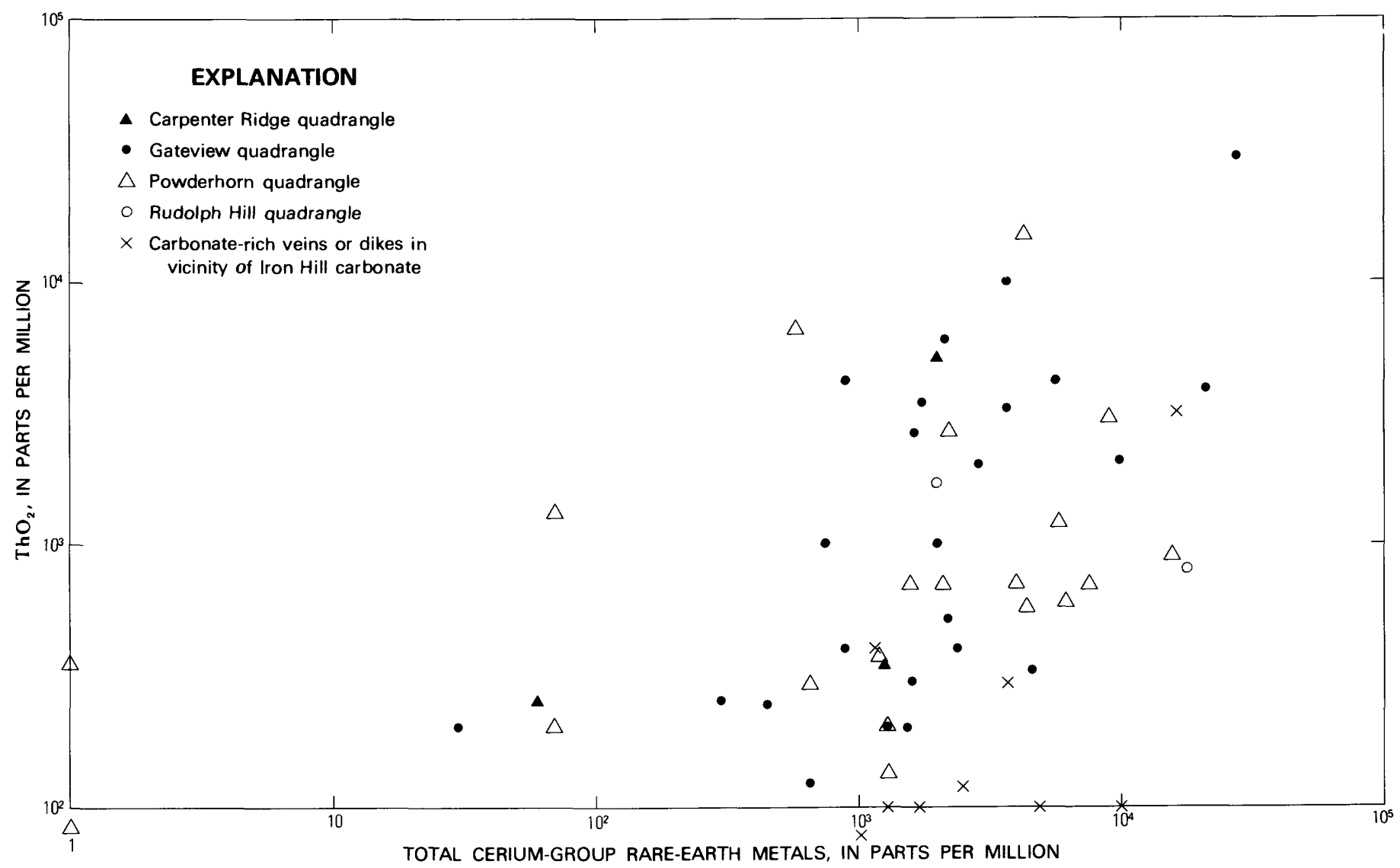

FIGURE 24.-Graph showing relation of total cerium-group rare-earth metals to $\mathrm{ThO}_{2}$ content in 59 samples of thorium deposits. 


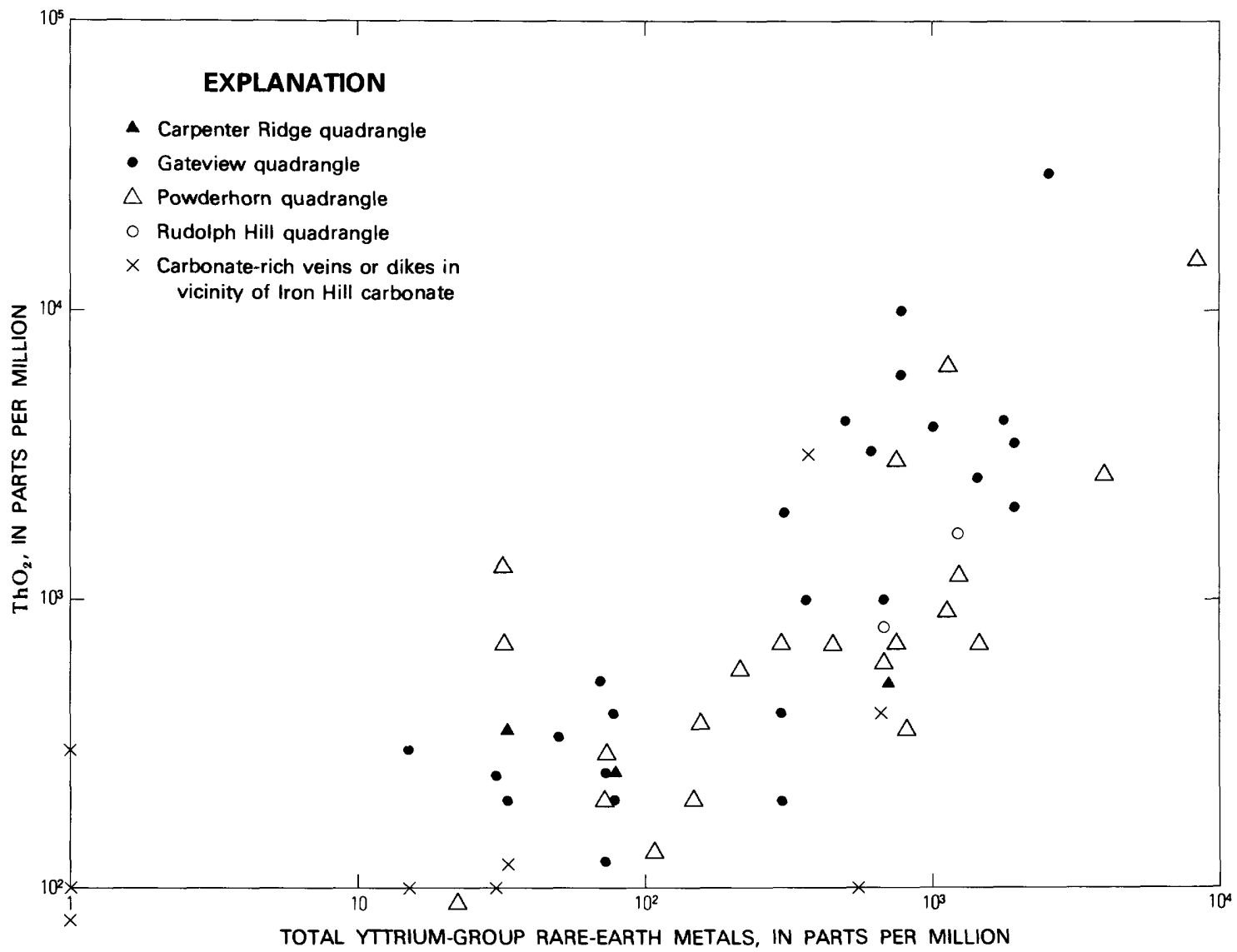

FIGURE 25.-Relation of total yttrium-group rare-earth metals to $\mathrm{ThO}_{2}$ content in 59 samples of thorium deposits. Rare-earth values approximated from semiquantitative spectrographic analyses.

to 130 in 10,130 to 1,000 or more in 14 , and in 16 of the samples the thorium-uranium ratio is probably high but the uranium content is very low or not determined. The ratio of thorium to uranium is also generally high in rocks other than the thorite veins, such as carbonatite dikes and thorium-bearing granite. In 23 samples of carbonatite or alkalic rocks, uranium exceeds $10 \mathrm{ppm}$ in only one, a carbonatite dike sample in which it is $93.4 \mathrm{ppm}$, exceeding thorium. Significant uranium resources therefore seem unlikely to be associated with the thorium deposits and alkalic igneous rocks in the district.

\section{REFERENCES}

Armbrustmacher, T. J., 1980, Abundance and distribution of thorium in the carbonatite stock at Iron Hill, Powderhorn district, Gunnison County, Colorado: U.S. Geological Survey Professional Paper 1049-B, p. B1-B11.

Armbrustmacher, T. J., and Brownfield, I. K., 1979, The carbonatite stock at Iron Hill, Gunnison County, Colorado-Chemical and mineralogical data: U.S. Geological Survey Open-File Report 79-537, $10 \mathrm{p}$.
Berkenkotter, R. D., and Hazen, S. W., 1963, Statistical analysis of diamond-drill sample data from the Cebolla Creek titaniferous iron deposit, Gunnison County, Colo.: U.S. Bureau of Mines Report of Investigations 6234, $58 \mathrm{p}$.

Burbank, W. S., and Pierson, C. T., 1953, Preliminary results of radiometric reconnaissance of parts of the northwestern San Juan Mountains, Colorado: U.S. Geological Survey Circular 236, $11 \mathrm{p}$.

Dooley, J. R., Jr., and Hathaway, J. C., 1961, Two occurrences of thorium-bearing minerals with rhabdophane-like structure: U.S. Geological Survey Professional Paper 424-C, p. C339-C341.

Ervin, Guy, Jr., and Osborn, E. F., 1949, X-ray data on synthetic melilites: American Mineralogist, v. 34, nos. 9-10, p. 717-722.

Fischer, R. P., 1975, Vanadium resources in titaniferous magnetite deposits: U.S. Geological Survey Professional Paper 926-B, $10 \mathrm{p}$.

Harrer, C. W., and Tesch, W. J., Jr., 1959, Reconaissance of iron occurrences in Colorado: U.S. Bureau of Mines Information Circular 7918, $82 \mathrm{p}$.

Hedlund, D. C., and Olson, J. C., 1961, Four environments of thorium-, niobium-, and rare-earth-bearing minerals in the Powderhorn district of southwestern Colorado: U.S. Geological Survey Professional Paper 424-B, p. B283-B286.

1973 [1974], Geologic map of the Carpenter Ridge quadrangle, Gunnison County, Colorado: U.S. Geological Survey Geologic Quadrangle Map GQ-1070, scale 1:24,000.

1975, Geologic map of the Powderhorn quadrangle, Gunnison 
and Saguache Counties, Colorado: U.S. Geological Survey Geologic Quadrangle Map GQ-1178, scale 1:24,000.

1980, Chemical, spectrographic, and modal analyses of syenitic rocks, thorium veins, and carbonatite in the Powderhorn district, Gunnison County, Colorado: U.S. Geological Survey Open-File Report 80-233, 36 p.

Heinrich, E. W., and Anderson, R. J., 1965, Carbonatites and alkalic rocks of the Arkansas River area. Fremont County, Colorado. 2. Fetid gas from carbonatite and related rocks: American Mineralogist, v. 50, nos. 11 and 12, p. 1914-1920.

Hunter, J. F., 1925, Pre-Cambrian rocks of Gunnison River, Colorado: U.S. Geological Survey Bulletin 777, 94 p.

Larsen, E. S., Jr., 1942, Alkalic rocks of Iron Hill, Gunnison County, Colorado: U.S. Geological Survey Professional Paper 197-A, p. 1-64.

Lemons, J. F., Jr., and Coppa, L. V., 1979, Mining and processing methods and cost models for the recovery of thorium from domestic occurrences: U.S. Department of Energy report GJBX-91(79), 68 p.

Nash, W. P., 1972, Mineralogy and petrology of the Iron Hill carbonatite complex, Colorado: Geological Society of America Bulletin, v. 83, no. 5, p. 1361-1382.

Olson, J. C., 1974 [1975], Geologic map of the Rudolph Hill quadrangle, Gunnison, Hinsdale, and Saguache Counties, Colorado: U.S. Geological Survey Geologic Quadrangle Map GQ-1177, scale 1:24,000.

Olson, J. C., and Hedlund, D. C., 1973 [1974], Geologic map of the Gateview quadrangle, Gunnison County, Colorado: U.S.
Geological Survey Geologic Quadrangle Map GQ-1071, scale $1: 24,000$.

Olson, J. C., Marvin, R. F., Parker, R. L., and Mehnert, H. H., 1977, Age and tectonic setting of lower Palezoic alkalic and mafic rocks, carbonatites, and thorium veins in south-central Colorado: U.S. Geological Survey Journal of Research, v. 5, no. 6, p. 673-687.

Olson, J. C., and Overstreet, W. C., 1964, Geologic distribution and resources of thorium: U.S. Geological Survey Bulletin 1204, $61 \mathrm{p}$.

Olson, J. C., Shawe, D. R., Pray, L. C., and Sharp, W. N., 1954, Rareearth mineral deposits of the Mountain Pass district, San Bernardino County, California: U.S. Geological Survey Professional Paper 261, 75 p.

Olson, J. C., and Wallace, S. R., 1956, Thorium and rareearth minerals in the Powderhorn district, Gunnison County, Colorado: U.S. Geological Survey Bulletin 1027-0, p. 693-723.

Rose, C. K., and Shannon, S. S., 1960, Cebolla Creek titaniferous iron deposits, Gunnison County, Colorado: U.S. Bureau of Mines Report of Investigations 5679, $30 \mathrm{p}$.

Staatz, M. H., Armbrustmacher, T. J., Olson, J. C., Brownfield, I. K., Brock, M. R., Lemons, J. F., Jr., Coppa, L. V., and Clingan, B. V., 1979, Principal thorium resources in the United States: U.S. Geological Survey Circular 805, 42 p.

Temple, A. K., and Grogan, R. M., 1965, Carbonatite and related alkalic rocks at Powderhorn, Colorado: Economic Geology, v. 60 , no. 4 , p. $672-692$. 